\title{
A vegetation index of biotic integrity for small-order streams in southwest Montana and a floristic quality assessment for western Montana wetlands.
}

Prepared for:

Montana Department of Environmental Quality

and

U.S. Environmental Protection Agency

By:

W. M. Jones

Montana Natural Heritage Program

Natural Resource Information System

Montana State Library

August 2005

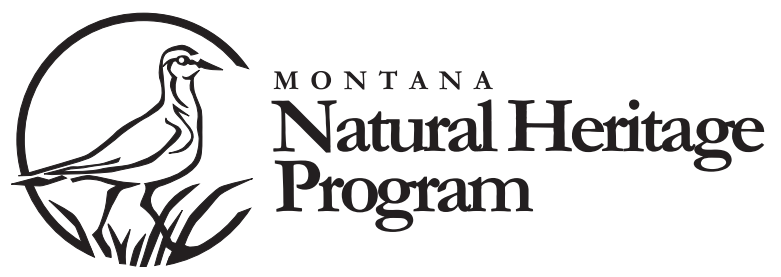





\title{
A vegetation index of biotic integrity for small-order streams in southwest Montana and a floristic quality assessment for western Montana wetlands.
}

\author{
Prepared for: \\ Montana Department of Environmental Quality \\ and \\ U.S. Environmental Protection Agency
}

Agreement Number:

203097

By:

W. M. Jones
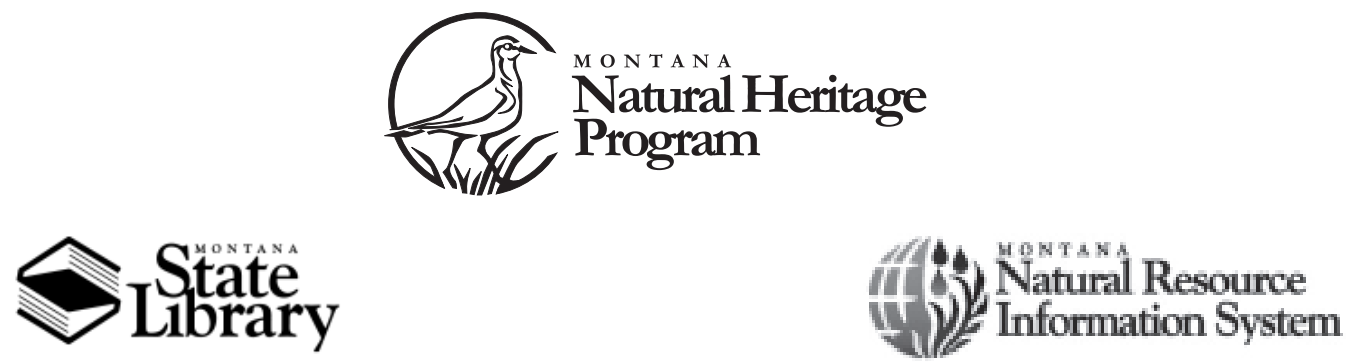

(C) 2005 Montana Natural Heritage Program

P.O. Box 201800 • 1515 East Sixth Avenue • Helena, MT 59620-1800 • 406-444-5354 
This document should be cited as follows:

Jones, W. M. 2005. A vegetation index of biotic integrity for small-order streams in southwestern Montana and a floristic quality assessment for western Montana wetlands. Report to the Montana Department of Environmental Quality and U.S. Environmental Protection Agency, Montana Natural Heritage Program, Helena, Montana. 29 pp. plus appendices. 


\begin{abstract}
This study evaluated the relationship between grazing-related disturbances and vegetation in firstthrough third-order montane streams in southwestern Montana. Eight vegetation metrics (relative cover of native graminoids, relative cover of exotic species, relative cover of hydrophytes, cover-weighted floristic quality index, coverweighted mean bank stability rating, absolute combined cover of seedling and young willows, and willow seedling density) were found to respond to grazing-related disturbances. These metrics were combined into a multimetric index, the vegetation
\end{abstract}

index of biotic integrity (VIBI), which responded strongly to a grazing-associated disturbance gradient. VIBI scoring thresholds were established that differentiated among three condition classes: reference condition, moderately impaired, and severely impaired. The VIBI can be used as an evaluation tool to assess riparian area condition. Coefficients of conservatism, which form the basis for floristic quality assessments, were assigned by an expert panel for plant species likely to occur in western Montana wetlands. 


\section{ACKNOWLEDGMENTS}

This study was funded through a U.S.

Environmental Protection Agency wetland

protection grant administered by the Montana

Department of Environmental Quality. My sincere

thanks to all who assisted with this project: Lynda

Saul, for her tireless efforts as the linchpin for

wetland conservation at Montana DEQ; Randy

Apfelbeck, Anna Noson, and Bryce Maxell, for their fruitful involvement with the wetland monitoring and assessment work group; Steve Cooper, for his review of riparian assessment methods; and Greg Kudray and Coburn Currier for editing and formatting the final version of this report. My highest thanks also to Peter Lesica, John Pierce, Steve Shelly, Mary Manning, Steve Cooper, and Scott Mincemoyer for their invaluable help in assigning coefficients of conservation to western Montana wetland plants. 


\section{TABLe OF Contents}

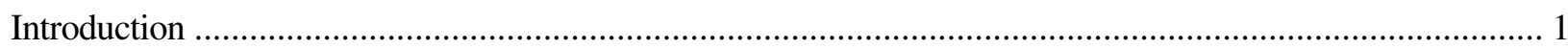

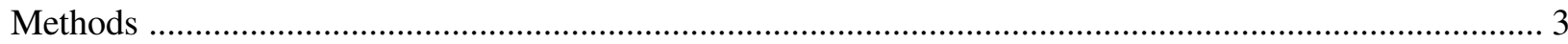

Study Area

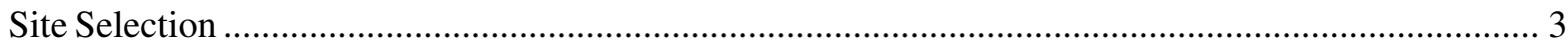

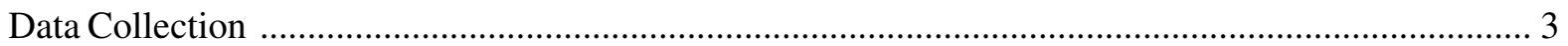

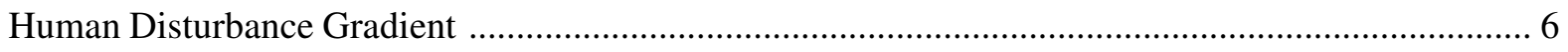

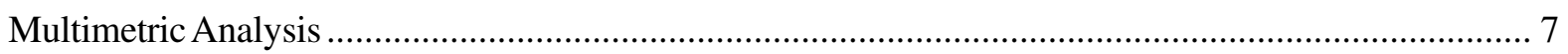

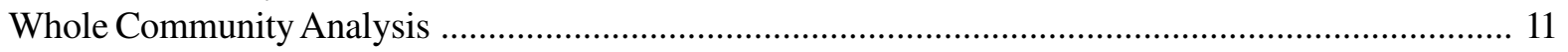

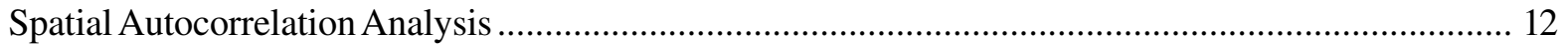

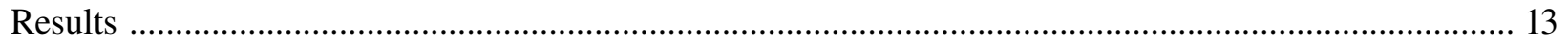

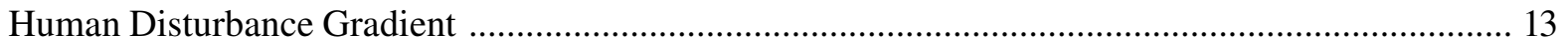

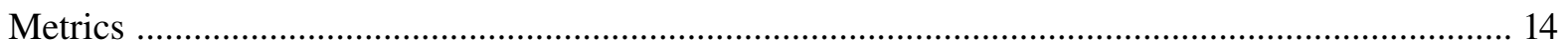

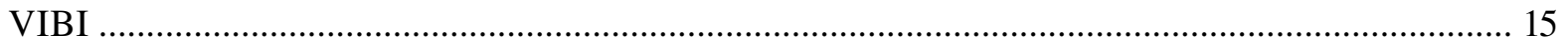

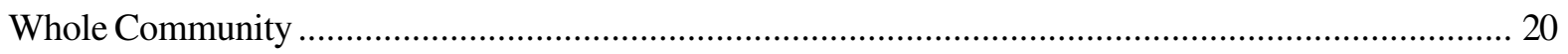

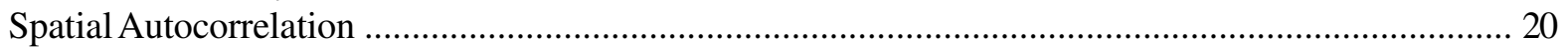

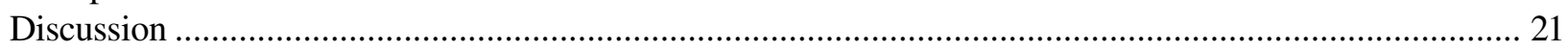

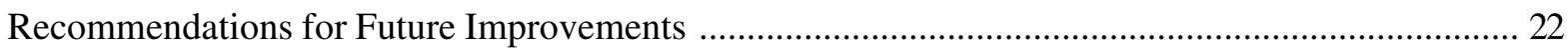

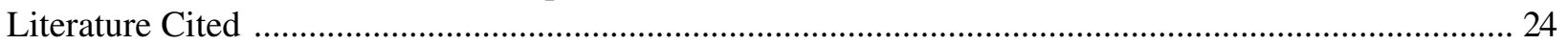

Appendix A. Coefficients of conservation for selected wetland plants that occur in western Montana.

Appendix B. List and attributes of sampled plant species.

Appendix C. Location and condition rating of sample reaches.

\section{LiST OF Figures}

Figure 1. Location and functional condition classes of sample reaches .................................................. 4

Figure 2. Schematic showing placement of and data collected for subsamples within sample reaches ..... 5

Figure 3. Graphical representation of the relationship between PFC categories and the composite disturbance gradient

Figure 4. Discriminatory power of selected metrics and their relationship with a composite human disturbance gradient

Figure 5. Scatterplot showing the relationship between the vegetation index of biotic integrity (VIBI) and a composite human disturbance gradient ........................................................ 15

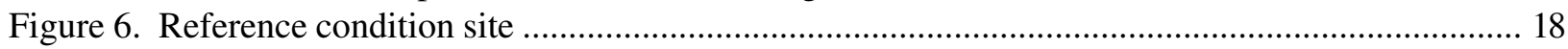

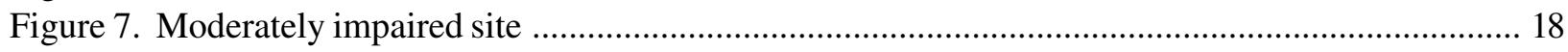

Figure 8. Severely impaired site ................................................................................................. 18

Figure 9. Tree diagram showing VIBI scoring thresholds associated with disturbance categories and scatterplot of the composite disturbance gradient and VIBI .......................................... 19

Figure 10. Graphical representation of the NMS ordination of sample reaches ................................... 20

\section{LisT OF TABLES}

Table 1. Age classes for woody shrub and deciduous tree species ...................................................... 5

Table 2. Coefficient of conservatism scoring criteria …........................................................................ 8

Table 3. Contribution of individual disturbance factors to a composite disturbance measure extracted by principal components analysis 


\section{LiST OF TABLES (CONTINUED)}

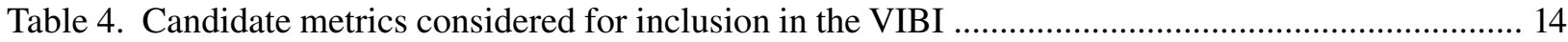

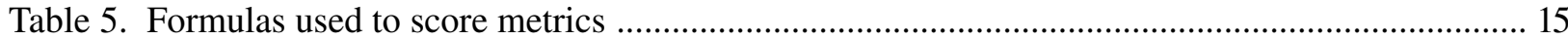

Table 6. Accuracy assessment of VIBI scoring thresholds with regard to disturbance classes ............... 18

Table 7. Species indicative of reference, moderately disturbed, and severely disturbed sites .................. 19 


\section{INTRODUCTION}

The list of economic and environmental benefits provided by wetlands and riparian areas is long. These benefits include groundwater recharge, filtration and storage of sediments, nutrients, and pollutants, floodwater storage and attenuation, and unique habitat values (Brinson et al. 1981, Keddy 2000). Consequently, the importance of wetlands and riparian areas is disproportionate to their physical extent on the landscape, especially in semiarid regions such as Montana (Finch and Ruggiero 1993, Patten 1998). Despite their importance to both humans and wildlife, an estimated 25\% of Montana's wetlands have been lost in the past 200 years (Dahl 1990). To improve wetland conservation in Montana, the Montana Department of Environmental Quality (DEQ) is developing a comprehensive statewide wetland monitoring and assessment program, of which this present study is a part.

This program will use a three-tiered approach to characterize the condition and extent of wetlands in Montana. DEQ will combine landscape-level remotely sensed data, rapid site-level assessments, and detailed site-level evaluations of biota to evaluate wetland condition and to identify anthropogenic stressors that limit that condition. The purpose of the present study was to identify attributes of the riparian vegetation community of small-order streams that responded predictably to human disturbance. Such attributes could then be used as indicators of wetland condition for detailed site assessments as well as for validating and calibrating rapid assessment methods.

I used a multimetric approach to identify vegetation indicators. Multimetric analysis attempts to determine the status of a wetland or stream reach by directly measuring the condition of one or more of its biotic components (Danielson 2002). This method is based on defining a relatively homogenous study environment and measuring the response of target biota across a human disturbance gradient (Karr and Chu 1999). Ideally, successful metrics should be attributes of the biota that change predictably with increasing human disturbance, are sensitive to a range of biological stresses, discriminate between humancaused perturbations and natural variability, and are easy to measure and interpret (Karr and Chu 1999). Successful metrics can then be combined into a multimetric index that reflects a diverse biotic response to human-related stressors and is an integrative measure of the site's biological condition (Karr and Chu 1999, Teels and Adamus 2002).

Biological assessments can be accurate and cost-effective tools to assess wetland and stream condition and to measure impairment (Karr and Chu 1999). Since biota integrate multiple physical and chemical parameters, directly measuring a biotic community's response to anthropogenic stressors can be the most effective means to evaluate the effect of those stressors on wetland condition and function (Danielson 2002). The utility of using biota to assess wetlands has been demonstrated for numerous taxa, including fish (Karr 1981, Hughes et al. 1998, Mebane et al. 2003), diatoms (Fore and Grafe 2002), benthic and terrestrial macroinvertebrates (Kimberling et al. 2001, Blocksom et al. 2002, Klemm et al. 2003), birds (Bryce et al. 2002), and vegetation (DeKeyser et al. 2003, Mack 2004, Ferreira et al. 2005). This approach has been shown to be effective for perennial and seasonal depressional wetlands and ephemeral and intermittent streams in Montana (Apfelbeck 2001, Jones 2004).

This study was conducted in southwestern Montana where the primary human-related stressors are livestock grazing and agriculture. Livestock grazing can influence numerous physical parameters in riparian systems, including stream channel and bank geomorphology and stability (Kauffman et al. 1983b, Clary 1999, Clary and Kinney 2002), floodplain microchannel sinuosity and drainage density (Flenniken et al. 2001), and soil bulk density, pore space, infiltration, and potential nitrification and mineralization rates (Kauffman and Krueger 1984, Wheeler et al. 2002, Kauffman et al. 2004). By altering these physical parameters as well as by directly removing plant biomass, grazing can significantly affect riparian vegetation. Livestock grazing can decrease belowground biomass (Kauffman et al. 2004), decrease the abundance of woody vegetation, especially willows (Kauffman et al. 1983a, Schulz and Leininger 1990, Clary 1999, Brookshire et al. 
2002, Thorne et al. 2005), and increase the abundance of weedy species, such as Kentucky bluegrass (Poa pratensis L.) (Schulz and Leininger 1990, Green and Kauffman 1995), possibly by altering competitive interactions with native graminoids (Martin and Chambers 2001). At lower elevations, agricultural land uses and their associated hydrologic modifications become important stressors on riparian systems; however, this study was conducted on smaller order streams that were largely unaffected by agricultural disturbances. 


\section{METHODS}

\section{Study Area}

The study area encompassed portions of Beaverhead and Madison Counties in southwest Montana (Figure 1). This area lies within the Northern Rocky Mountain and Montana Valley and Foothill Prairies Ecoregions (Woods et al. 1999) and is characterized by broad intermontane valleys interspersed with isolated mountain ranges. The geology is a complex mixture of predominately Tertiary and Cretaceous sedimentary rocks with localized intrusions of Tertiary volcanics, Mississippian limestone, Proterozoic quartzite, and Archaean gneiss and schist; Pleistocene glacial deposits are locally abundant at higher elevations (Ruppel et al. 1993, Ruppel 1999, Lonn et al. 2000, Skipp and Janecke 2004). The climate is semiarid and continental. The weather station at Lima, Montana, which is representative of lower elevation sample locations, has recorded mean temperatures ranging from $16.8^{\circ} \mathrm{F}$ in January to $61.3^{\circ} \mathrm{F}$ in July and mean precipitation of 12.43 inches annually (Western Regional Climate Center 2005).

\section{Site Selection}

Potential sample locations were limited to smallorder streams that had been previously evaluated for functional status by the Bureau of Land Management (BLM) and U.S. Forest Service (USFS) using standardized riparian assessments. BLM assessments used the proper functioning condition (PFC) methodology, which combines qualitative evaluations of hydrology, vegetation, and erosion/deposition to evaluate a stream reach (Prichard et al. 1998). USFS assessments evaluated a stream reach's degree of departure from reference condition using quantitative hydrogeomorphological parameters (Bengeyfield 1999). The output of both evaluation methods is to assign a stream reach into one of three condition classes: functioning (or proper functioning condition), functioning at risk, and nonfunctioning. To encompass variability in the degree of humanrelated disturbance, potential sample reaches were stratified by condition class. Rated reaches were displayed in a geographic information system (ArcGIS 8.3, ESRI, Redlands, California), and 11 functioning, 9 functioning at risk, and 10 nonfunctioning reaches were selected. All 30 stream reaches were sampled from June to August 2004.

Sample reaches were first- through third-order, low gradient streams ranging in elevation from 6,000 to 7,900 feet above sea level; most reaches would be categorized as "E" type streams under Rosgen's (1996) classification system. All sample reaches were on tributaries to the Beaverhead and Red Rock Rivers on lands managed by the BLM or USFS and supported varying levels of willow cover, predominately Geyer's willow (Salix geyeriana Anderss.), Booth's willow (S. boothii Dorn), and Drummond's willow (S. drummondiana Barratt ex Hook.). Dominant herbaceous species included beaked sedge (Carex utriculata Boott), water sedge (C. aquatilis Wahlenb.), Baltic rush (Juncus balticus Willd.), bluejoint reedgrass

(Calamagrostis canadensis (Michx.) Beauv.), and Kentucky bluegrass.

\section{Data Collection}

The sampling method used to collect species abundance and environmental data was modified from the techniques outlined in Winward (2000) and Coles-Ritchie et al. (2004) and was selected based in part on a review by Cooper (2004). The sample unit was a 100-m stream reach that was subsampled using two types of systematically placed sample frames: $0.1-\mathrm{m}^{2}(0.2-\mathrm{m} \times 0.5-\mathrm{m})$ quadrats and $4-\mathrm{m}^{2}$ (1.13-m radius) plots. Sample frames were placed along transects running perpendicular and parallel to the stream channel, such that an area of $100-\mathrm{m} \times 8$-m was sampled along each side of the stream channel (Figure 2).

Streambank sampling was conducted along the greenline, which is defined as the first perennial vegetation that forms a lineal grouping of community types on or near the channel edge and usually occurs at or slightly below bankfull discharge (Winward 2000). Greenline sampling consisted of 20 quadrats placed at 5-m intervals 
Figure 1. Locations and functional condition classes of sample reaches. Condition classes are PFC (proper functioning condition), FAR (functioning at risk), and NF (nonfunctioning)

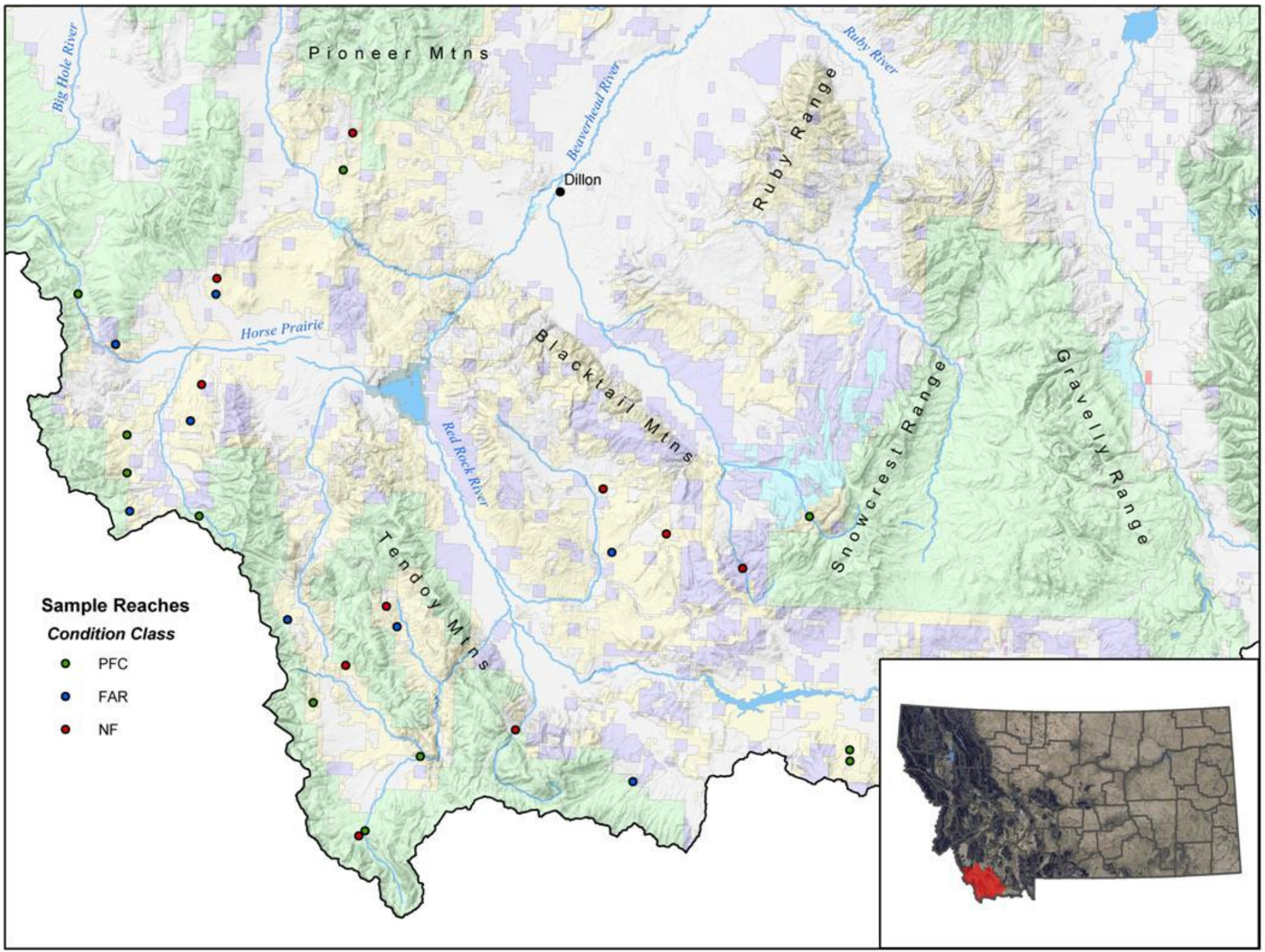




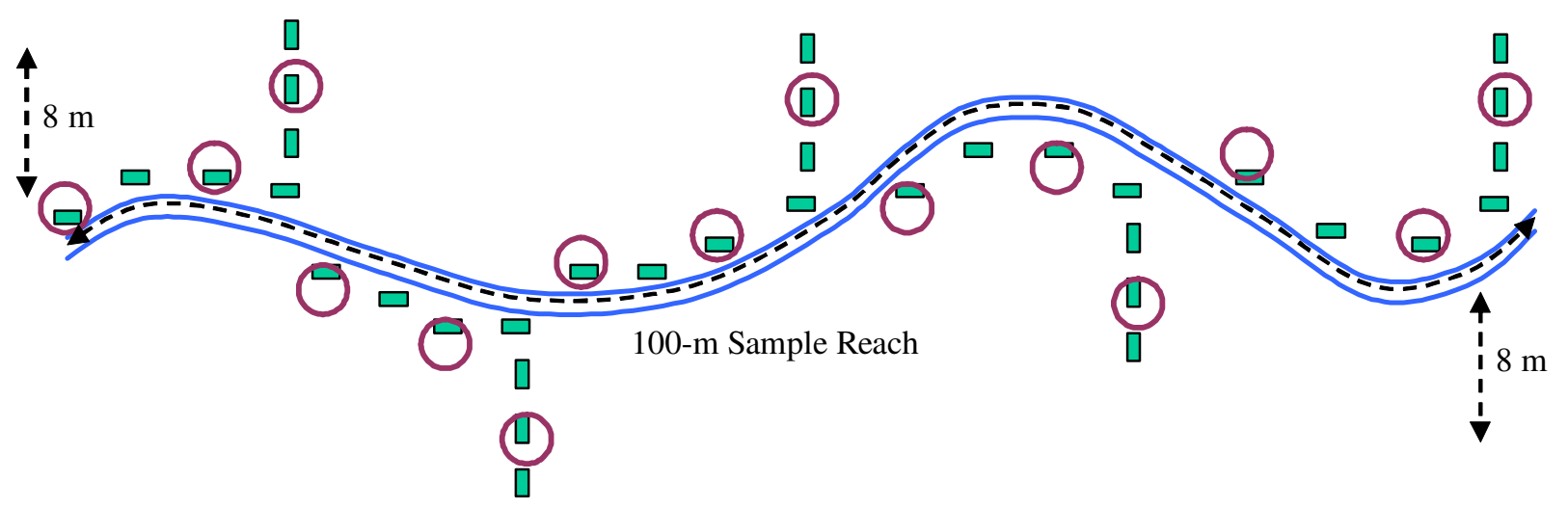

$\square \quad$ 0.2-m $\times 0.5-\mathrm{m}$ quadrat (abundance of herbaceous vegetation, bare ground, height above bankfull discharge)

4- $\mathrm{m}^{2}$ circular plot (abundance of woody vegetation, pugging/hummocking density, bank stability, browse intensity)

Figure 2. Schematic showing placement of and data collected for subsamples within sample reaches.

and 10 plots placed at $10-\mathrm{m}$ intervals, with groups of four quadrats and one plot being placed on alternating sides of the channel, with the long ends of quadrats placed parallel to the channel. Five transects were also placed perpendicular to the valley slope at an interval of $20 \mathrm{~m}$ on alternating sides of the channel. Three quadrats (located 2.5, 5.0 , and $7.5 \mathrm{~m}$ from the greenline with long ends parallel to the transect) and one plot (located $5.0 \mathrm{~m}$ from the greenline) were sampled at each transect.

Species abundances were recorded using the cover estimation method described by Daubenmire (1959). Six cover classes were used to record species abundances: 1 (<5\% cover), $2(5-25 \%$ cover), 3 ( $25-50 \%$ cover), 4 ( $50-75 \%$ cover), 5 (75$95 \%$ cover), and 6 ( $>95 \%$ cover). Herbaceous vegetation was sampled in quadrats and woody vegetation was sampled in plots. For woody species, both total cover and cover by age class (Table 1) were estimated. Mean height for each age class was estimated to the nearest $0.1 \mathrm{~m}$. The number of woody seedlings present in each plot was also recorded. Species nomenclature follows the PLANTS database (version 3.5), which is the national naming standard used by the federal government (Natural Resources Conservation Service 2004).

Five potential indicators of grazing-related stressors were measured: (1) amount of bare ground, (2) number of hoof shears (pugs) present in each plot, (3) number and mean depth of hummocks present in each plot, (4) bank stability at greenline plots, and (5) browse intensity. Bare ground was measured as the number of quadrat corners that intersected bare mineral soil. Bank stability was evaluated with a $0.15-\mathrm{m}$ wide plot running from the scour line to either twice bankfull height or a flat depositional surface, whichever was lower. A bank was considered unstable if less than $50 \%$ of the plot was covered by perennial vegetation ground cover or roots, rocks greater than $0.15-\mathrm{m}$ diameter, or logs greater than $0.1-\mathrm{m}$

Table 1. Age classes for woody shrub and deciduous tree species.

\begin{tabular}{lcc}
\hline & \multicolumn{2}{c}{ Description } \\
\cline { 2 - 3 } Age Class $^{\mathrm{a}}$ & Woody Shrubs & Deciduous Trees \\
\hline seedling & $1 \mathrm{stem}$ & $<0.3 \mathrm{~m}$ tall \\
young & $2-10 \mathrm{stems}$ & $0.3-2 \mathrm{~m}$ tall \\
mature & $>10$ stems, $>1 / 2$ alive & $>2 \mathrm{~m} \mathrm{tall},>1 / 2$ alive \\
decadent/dead & $>10$ stems, $<1 / 2$ alive & $>2 \mathrm{~m}$ tall, $<1 / 2$ alive \\
\hline${ }^{a}$ age class determinations were not made for rhizomatous shrub species
\end{tabular}


diameter, either singly or in combination. Browse intensity was evaluated following the method of Keigley and Frisina (1998). The plant nearest the plot center with a primary stem between 0.5 and $1.5 \mathrm{~m}$ high was selected for evaluation; if only taller plants were present, the plant nearest the plot center that had a primary stem with a terminal leader within the browse zone (0.5 to $1.5 \mathrm{~m}$ high) that was not mechanically protected was selected. If browsing had killed an entire annual segment on the stem selected, browse intensity was considered heavy; if not, browse intensity was considered light to moderate. This evaluation was performed only if a palatable species with a terminal leader within the browse zone was present (e.g., Salix spp., Cornus sericea L., Populus tremuloides Michx.). Finally, the elevation of greenline quadrats in relation to bankfull discharge was measured to the nearest $0.01 \mathrm{~m}$.

To determine whether the number of subsamples was adequately characterizing vegetation, I examined species area curves for the initial five sites surveyed to see if they met the criterion of less than a 5\% increase in the number of species sampled for a $10 \%$ increase in sample area (Mueller-Dombois and Ellenberg 1974). All five sites met this threshold by the time $80 \%$ of the area had been surveyed; therefore, the sampling intensity was considered adequate.

All data were aggregated to the level of sample reach. Vegetation abundance was calculated by averaging cover class midpoints. Values for all other variables were averaged except for browse intensity and bank stability, which were calculated as frequencies.

\section{Human Disturbance Gradient}

Disturbance parameters measured on-site were chosen to be responsive to grazing-related stresses. Two other factors were calculated: allotment stocking rates, which were measured as the number and duration of cow-calf pairs allowed on the allotment (animal unit months (AUMs)), and road density of upstream catchments. The extent of road development was calculated from 2000 TIGER 1:100,000 line files (US Census Bureau 2003), and catchments were delimited with the hydrology modeling extension in ArcGIS using a sink-filled digital elevation model (30-m raster National Elevation Dataset, US Geological Survey 2002). Another commonly used disturbance indicator, percent of catchment in agricultural or other human-modified land cover, was not considered because catchment land cover was comprised almost entirely of native vegetation for all sites. The interpretation of this measurement has also been shown to be problematic because of spatial autocorrelation among land cover classes (King et al. 2005).

To rank sites by their overall disturbance, I calculated a composite disturbance measure using principal components analysis (PCA). PCA identifies linear combinations of the variables that explain the greatest variation in the data. The original dataset can thereby be represented in fewer dimensions with composite variables, termed principal components, than the number of original descriptors. Although PCA was developed for data with multivariate normal distributions, it is robust to departures from normality as long as factors are relatively unskewed (Legendre and Legendre 1998). Disturbance factors were transformed to meet the threshold recommended by McCune and Grace (2002) of Iskewnessl $<1$. The best normalizing power transformation for each variable was estimated using the unconditional Box-Cox maximum likelihood function (Box and Cox 1964), except for the frequency variables bank stability and browse intensity, which were arcsine square root-transformed. Power transformation estimates were calculated using the companion to applied regression (car) package (Fox 2005) for the $\mathrm{R}$ statistical environment (Ihaka and Gentleman 1996, R Development Core Team 2005). Data were standardized by ranging such that values varied from $[0,1]$. PCA was run on the variancecovariance cross-products matrix of the descriptor variables. The resulting composite axes were determined to be interpretable if they explained more variation in the data than that expected by chance using Frontier's (1976) broken stick model (Jackson 1993).

I compared the derived composite disturbance gradient with the proper functioning condition categories used to initially stratify sites. I used one-way analysis of variance with multiple comparisons to test whether mean composite 
disturbance scores were different among PFC categories. To compensate for multiple testing, significance values were modified with a Bonferroni correction (Sokal and Rohlf 1995). Assumptions of analysis of variance (normal distribution of residuals and homogenous error variances) were examined graphically and with Levene's test (Levene 1960). Because BLM and USFS methodologies differed somewhat, I tested all sites $(\mathrm{n}=30)$ and sites on BLM land $(\mathrm{n}=23)$. Sites on USFS land were not tested independently due to small sample size $(n=7)$.

\section{Multimetric Analysis}

Vegetation response to the composite disturbance gradient was quantified by developing a multimetric index, termed the vegetation index of biotic integrity (VIBI). VIBI development included several steps. Candidate metrics were screened for their ability to discriminate between least and most disturbed sites and for their overall response to the disturbance gradient. Metrics found to be responsive to human disturbance were tested for redundancy and the most responsive, nonredundant metrics were combined into the VIBI. Metric and VIBI analyses were conducted using $\mathrm{R}$ statistical software, except where otherwise noted.

\section{Candidate Metrics}

Vegetation attributes that have been considered in other studies fall into several categories: community-based metrics (e.g., species richness and dominance), metrics based on plant functional groups (e.g., annuals, perennials, disturbancetolerant species), and species-specific metrics (Fennessy et al. 2002). Potential metrics considered in this study were largely derived from the second category. Among those considered were metrics that had been proven to be effective in previous studies (Borth 1998, Helgen and Gernes 2001, DeKeyser et al. 2003, Mack 2004, Jones 2004). Twenty-seven metrics from the following categories were evaluated.

Metrics based on growth form, taxonomy, and nativity - This group comprised the largest number of candidate metrics. Candidate metrics expected to decrease with increasing disturbance were the relative cover of native perennials, native graminoids, and Carices. Those expected to increase with disturbance included the relative cover of exotic species, exotic grasses, and annuals/biennials. Several metrics related to the woody vegetation component were also considered, including density of willow seedlings, cover of willow seedlings, cover of young willows, combined cover of willow seedlings and young willows, total willow cover, and willow age distribution, which was calculated as the combined cover of willow seedlings and young willows divided by total willow cover. Cover values for willow-related metrics were calculated with absolute cover values to emphasize structural differences among sites. All were expected to decrease with human disturbance.

Metrics based on diversity measures - Two diversity measures, the Shannon index and the reciprocal of the Simpson dominance index, were calculated. Both indices are related to and based partly on species richness; however, they also incorporate the equitability of species abundances as well. For example, both indices would rate a plot with one dominant and two incidental species as less diverse than a plot with three equally abundant species. Shannon diversity is calculated as

$$
\mathrm{H}^{\prime}=-\sum p_{i} \log p_{i}
$$

where $\mathrm{H}^{\prime}$ is the Shannon diversity index and $p_{i}$ is the relative cover of species $i$ within a sample unit. Simpson diversity is calculated as

$$
\mathrm{D}=1 / \sum p_{i}^{2}
$$

where D is the Simpson diversity index. These two measures are similar but vary in their sensitivity to rare species, with Simpson diversity being intermediate between species richness and Shannon diversity in its sensitivity (McCune and Grace 2002). Both indices were expected to decrease with disturbance.

Metrics based on floristic quality - The concept of floristic quality derives from a plant community assessment method developed by 
Swink and Wilhelm (1979). Their floristic quality assessment index (FQAI) is based on the perceived affinity of native plant species to particular habitats and their tolerance to disturbance. Within a regional flora, each species' affinity/tolerance is subjectively quantified using an 11-point ordinal standard termed the coefficient of conservatism $(C)$ (Table 2). $C$-values are assigned by an expert panel of botanists familiar with the flora in question. Using $C$-values, the floristic quality, and by extension, condition, of different sites can be compared.

The FQAI and derived measures have proven to be highly sensitive indicators of disturbance. The usefulness of the FQAI as a vegetation metric has been demonstrated for prairie potholes and ephemeral streams in the Great Plains (Mushet et al. 2002, DeKeyser et al. 2003, Jones 2004), depressional wetlands in Florida (Cohen et al. 2004), numerous wetland types in Ohio (Lopez and Fennessy 2002, Andreas et al. 2004), and woodlands in southern Ontario (Francis et al. 2000).

Computationally, the FQAI is based on the mean $C$-value of a site's vegetation, which is calculated as:

$$
\text { mean } C_{j}=\sum C_{i j} / \mathrm{n}_{j}
$$

where $C_{i j}$ is the coefficient of conservatism of native species $i$ at site $j$ and $\mathrm{n}_{j}$ is the number of native species at site $j$. The FQAI score for site $j$ is calculated as:

$$
\mathrm{FQAI}_{j}=\sum C_{i j} / \sqrt{\mathrm{n}_{j}}=\left(\text { mean } C_{j}\right) \times \sqrt{\mathrm{n}_{j}}
$$

The square root modifier was proposed by Wilhelm and Ladd (1988) to dampen the effects of species richness on the index. This diminishes disparities between high quality species-poor sites and lower quality species-rich sites. $C$-values used in this study were determined by a panel of expert botanists and are listed in Appendix A.

I applied two modifications to the standard FQAI method similar to those proposed by Cohen et al. (2004). First, I included exotic species in the calculation of the FQAI, which are typically not considered. However, exotic species are an important indicator of site quality and their inclusion in the index seems warranted. The other modification was to weight each species' $C$-value by its relative abundance. Abundance is a more sensitive measure of species response than presence-absence (Rahel 1990), so it is possible that a cover-weighted FQAI may be a better indicator of site condition than the standard formulation. The cover-weighted FQAI (cFQAI) for site $j$ was calculated as:

$$
\mathrm{cFQAI}_{j}=\left[\sum\left(C_{i j} \times a_{i j}\right) / \sum a_{i j}\right] \times \sqrt{\mathrm{n}_{j}}
$$

where $a_{i j}$ is the abundance (measured as cover) of species $i$ at site $j$ and $C_{i j}$ is the coefficient of conservatism of species $i$ at site $j$. Exotic species were included in the calculation of the coverweighted FQAI. All calculations of mean $C$-value and FQAI were expected to decrease with disturbance.

In addition to the FQAI itself, there are several other potential metrics that can be derived from $C$ values. These include the relative cover of disturbance-tolerant species (species with $C$-values $\leq 2$ ) and disturbance-intolerant species (species with $C$-values $\geq 6$ ).

Metrics based on wetland indicator status Wetland indicator status is a reflection of a species' affinity for wetland habitats. Species are placed into one of five ordinal categories that represent the

Table 2. Coefficient of conservatism scoring criteria (after Andreas et al. 2004).

\begin{tabular}{cl}
\hline$C$ & Criteria \\
\hline 0 & $\begin{array}{l}\text { Plants with a wide range of ecological tolerances; often opportunistic invaders of natural areas or native } \\
\text { taxa that are typically part of a disturbed community. }\end{array}$ \\
$1-2$ & $\begin{array}{l}\text { Widespread taxa that occur in a variety of communities, including disturbed sites. } \\
3-5\end{array}$ \\
$\begin{array}{l}\text { Plants with an intermediate range of ecological tolerances that typify a stable phase of a native community, } \\
\text { but that persist under some disturbance. }\end{array}$ \\
$\begin{array}{l}\text { Plants with a narrow range of ecological tolerances that typify stable, relatively undisturbed communities. } \\
\text { Plants with a narrow range of ecological tolerances that exhibit high fidelity to narrow habitat require- } \\
\text { ments. }\end{array}$
\end{tabular}


likelihood of its occurring in wetlands versus nonwetlands. These categories, scored one through five, are: 1 = obligate upland (species occur almost exclusively in uplands), 2 = facultative upland (species usually occur in non-wetlands), $3=$ facultative (species equally likely to occur in wetlands or non-wetlands), 4 = facultative wetland (species usually occur in wetlands), and $5=$ obligate wetland (species occur almost exclusively in wetlands). Indicator status values were obtained from the 1988 national list and 1993 Pacific Northwest supplement published by the U.S. Fish and Wildlife Service (Reed 1993). Indicator values for the Pacific Northwest (Region 9) were used. These lists only identified obligate upland species if they occurred in wetlands in another region. Species sampled in this study that did not occur on the lists were coded as obligate upland species.

Three potential metrics were calculated from wetland indicator values: relative cover of hydrophytes (species with an indicator value of obligate or facultative wetland), relative cover of upland species (species with an indicator value of obligate or facultative upland), and the coverweighted mean wetland indicator value, which is calculated as:

$$
\mathrm{cWI}_{j}=\sum\left(\mathrm{WI}_{i j} \times a_{i j}\right) / \sum a_{i j}
$$

where $\mathrm{cWI}_{j}$ is the cover-weighted mean wetland indicator value for site $j, \mathrm{WI}_{i j}$ is the wetland indicator value of species $i$ at site $j$, and $\mathrm{a}_{i j}$ is the abundance of species $i$ at site $j$. Relative cover of hydrophytes and cWI were expected to decline with increasing disturbance, while the relative cover of upland-associated species was expected to increase.

Metrics based on bank stability rating - The last category of metrics were derived from the ability of species to stabilize streambanks either with deep binding root masses or other mechanical means (e.g., Abernathy and Rutherfurd 2001, Simon and Collison 2002). Ordinal stability ratings were assigned to species based on similar categorizations in Crowe and Clausnitzer (1997, Appendix D), Hansen et al. (1995, Appendix A-7), and the author's judgment. Ratings were scored as $1=$ poor, $2=$ fair, $3=$ good, and $4=$ excellent. Two potential metrics were calculated: relative cover of stabilizing species (species with stability ratings of good or excellent) and the cover-weighted mean bank stability rating, which was calculated as:

$$
\mathrm{cSR}_{j}=\sum\left(\mathrm{SR}_{i j} \times a_{i j}\right) / \sum a_{i j}
$$

where $\mathrm{cSR}_{j}$ is the cover-weighted mean vegetation stability rating for site $j, \mathrm{SR}_{i j}$ is the stability rating of species $i$ at site $j$, and $a_{i j}$ is the abundance of species $i$ at site $j$. Only data from greenline transects were used to calculate bank stability metrics. Both metrics were expected to decrease with disturbance. Stability ratings for species are listed in Appendix B.

\section{Metric Evaluation and Selection}

A three-step selection process was used to evaluate candidate metrics for inclusion in the VIBI, similar to Blocksom et al. (2002). The three criteria were the ability of metrics to discriminate between least and most disturbed sites, the overall relationship between metrics and the composite disturbance gradient, and redundancy among metrics. To test discriminatory power, I identified least disturbed sites (disturbance score $<25^{\text {th }}$ percentile of disturbance index) and most disturbed sites (disturbance score $>75^{\text {th }}$ percentile of disturbance index). Percentiles were calculated in the $\mathrm{R}$ statistical package using the method recommended by Hyndman and Fan (1996). Box plots were used to examine metric distributions. Metrics were scored based on their ability to differentiate between the two disturbance categories using the methodology described by Barbour et al. (1996). Metrics that had no overlap of interquartile range (middle $50 \%$ of observations) were scored 3, those that had no overlap of median and interquartile range were scored 2, those that had an overlap of one median and interquartile range were scored 1 , and those where both medians overlapped with interquartile ranges were scored 0 . Candidate metrics with scores of 2 or 3 were retained for further evaluation.

The overall relationship between metrics and disturbance was evaluated by examining scatterplots and Spearman rank correlation coefficients $\left(r_{s}\right)$. Metrics with either $\left|r_{s}\right|>0.5$ or a strong curvilinear relationship were retained. 
Finally, to ensure that metrics would not be providing redundant information to the VIBI, I examined correlations among the remaining candidate metrics. I used the high threshold recommended by the U.S. Environmental Protection Agency $\left(\left|\mathrm{r}_{\mathrm{s}}\right|>0.9\right)$ to determine redundancy (USEPA 1998). Where two or more metrics were found to be redundant, the one with the greatest discriminatory power and greatest response to disturbance was retained.

\section{Metric Scoring}

Metrics are usually scored by assigning value ranges to discrete categories depending on their deviation from an expected reference condition (Karr 1981, Wilcox et al. 2002, DeKeyser et al. 2003, Mack 2004). A commonly used scheme is to assign reference condition sites a score of 5 , sites that deviate somewhat from reference condition a score of 3, and sites that strongly deviate from reference condition a score of 1 (Karr and Chu 1999). However, others have suggested that scoring metrics along a continuous scale would be more accurate, less variable, and easier to interpret (Minns et al. 1994, Hughes et al. 1998, McCormick et al. 2001, Mebane et al. 2003). Blocksom (2003) found that continuous scoring improved the overall performance of the multimetric index when compared to discrete scoring methods.

Before scoring metrics I first identified the $95^{\text {th }}$ percentile value of each metric $\left(5^{\text {th }}\right.$ percentile value of metrics that increased in response to disturbance), which I used as the best expected value to reduce the effect of outliers (Barbour et al. 1999). Metrics were scored by linear interpolation. Scores of metrics that decreased in response to disturbance were calculated by dividing the observed value by the $95^{\text {th }}$ percentile value; scores of metrics that increased in response to disturbance were calculated by dividing the difference between the maximum and observed value by the difference between the maximum and $5^{\text {th }}$ percentile value. Percentile values were rounded to the nearest percent for metrics measured in percent cover, to the nearest hundredth for seedling density, and to the nearest tenth for cover-weighted averages. Resulting scores were truncated to range between $[0,1]$. Metrics with a curvilinear response to the disturbance gradient were log-transformed prior to scoring to improve linearity in their response to the composite disturbance gradient. Log transformations were chosen based on the BoxCox power transformation constrained by the disturbance gradient. The Box-Cox parameter was estimated using the MASS package (Venables and Ripley 2002) for R software.

\section{VIBI Scoring and Evaluation}

VIBI scores were calculated by averaging scores of selected metrics and multiplying by 100 .

The VIBI therefore ranged from 0 to 100 regardless of the number of metrics found to be interpretable. The strength of the relationship between the VIBI and the composite disturbance gradient was evaluated using ordinary least squares regression. Assumptions of linear regression (normal distribution, constant variance, and independence of errors) were examined graphically.

One application of the VIBI is to use it as a validation tool to assess the accuracy of rapid assessments. The output of the rapid assessment is an ordinal rating of wetland condition. To provide a congruent VIBI scoring system, I wanted to determine how many condition classes the VIBI could accurately distinguish and to identify scoring thresholds for those categories. To determine the number of condition classes, I first categorized the composite disturbance gradient into $k=3$ to 5 groups. I used the $25^{\text {th }}$ and $75^{\text {th }}$ percentiles to partition the disturbance gradient into three disturbance categories, the $25^{\text {th }}, 50^{\text {th }}$, and $75^{\text {th }}$ percentiles to partition it into four disturbance categories, and the $20^{\text {th }}, 40^{\text {th }}, 60^{\text {th }}$, and $80^{\text {th }}$ percentiles to partition it into five disturbance categories. One-way analysis of variance with multiple comparisons was used to test whether mean VIBI scores were different among disturbance categories and whether means for individual disturbance categories were different from one another. Significance values were modified with a Bonferroni correction. Only partitions where all VIBI means were different were considered useful. Analysis of variance assumptions were evaluated as described previously. 
VIBI scoring thresholds that best predicted membership to disturbance classes was identified using classification trees. Given a dataset with predefined groups, classification trees recursively partition that dataset into increasingly homogenous subsets with regard to the groups (Breiman et al. 1984, Urban 2002). At each partition, the tree algorithm identifies the scoring threshold for the predictor variable that best predicts group membership. This process continues until a minimum node size is met. Classification tree analysis was implemented using Therneau and Atkinson's (2005) rpart package for R software. Minimum node size to be split was set at 15 . Tree overfitting was controlled with an iterative 10 -fold cross-validation procedure. Classification accuracy was evaluated by comparing predicted to actual group membership.

Indicator species analysis was used to identify species that were strongly associated with VIBI condition categories. Indicator species analysis examines the frequency of occurrence and abundance of species within groups and assigns a group indicator value based on the specificity and fidelity of a species to that group (Dufrêne and Legendre 1997). Group indicator values range from 0 (no indication of group membership) to 100 (perfect indication). The strength of association was tested using a Monte Carlo randomization procedure with 10,000 iterations. Species with indicator values $>25$ and $P$-values $<0.1$ were reported. Indicator species analysis was performed using PC-ORD (McCune and Mefford 1999).

\section{Whole Community Analysis}

The vegetation metrics previously described represent the aggregated response of plant species with similar taxonomic or functional attributes to human disturbance. As a complement to the multimetric analysis, I also examined the simultaneous response of the entire vegetation community to human disturbance. Relationships among sample reaches in regard to the entire vegetation community were explored with nonmetric multidimensional scaling (NMS, Kruskal
1964, Mather 1976). NMS is an indirect ordination technique that attempts to describe underlying patterns of species composition by graphically summarizing complex relationships and displaying them in a few, usually two or three, dimensions (McCune and Grace 2002). NMS iteratively seeks the best representation of sample units in reduced space using an objective function, termed stress, that measures differences between ranked distances in the original multidimensional space and the reduced ordination space (Legendre and Legendre 1998). The global form of NMS was calculated using the Kulczynski distance measure (equivalent to the relativized form of the BrayCurtis (= Steinhaus) distance measure).

Dimensionality of the ordination was determined with PC-ORD's autopilot mode using 40 runs with real data and 50 runs with randomized data.

Dimensionality was chosen by selecting the highest number of dimensions that appreciably reduced stress and where the final stress was significantly lower than that for randomized data (McCune and Mefford 1999). The instability criterion to be achieved was set at 0.00001 after 500 iterations or within 50 continuous iterations. To reduce beta diversity (compositional heterogeneity among sample units (Whittaker 1972)) and improve the interpretability of results, species occurring in fewer than $5 \%$ of sample units were removed from the analysis.

The Mantel test (Mantel 1967) was used to evaluate whether the whole vegetation community was significantly correlated with the composite disturbance gradient. The Mantel test calculates linear or rank correlations between distance matrices derived from the original data tables. For this test, the Kulczynski and Euclidean distance measures were used to calculate distances for the species composition and disturbance matrices, respectively. The standardized Mantel statistic, $r_{M}$, which provides a measure of the strength of the correlation between the two matrices, was calculated on ranked distances and is equivalent to Spearman's rank correlation coefficient. Significance was tested by permutation with 10,000 iterations using the community ecology (vegan) package (Oksanen et al. 2005) for R software. 


\section{Spatial Autocorrelation Analysis}

Spatial autocorrelation can be broadly defined as a significant positive or negative correlation of the values of a variable as a function of distance (i.e., samples of a variable that are closer together in space having more similar values than those further away would be an example of positive spatial autocorrelation). Spatial autocorrelation is a very general phenomenon that operates at multiple scales for most ecological and environmental variables, and it is an important functional property of ecosystems (Legendre 1993). Autocorrelated data are problematic, however, because they violate an important assumption of many statistical tests, that observations of variables are independent from one another. The presence of positive autocorrelation between closely spaced observations distorts many tests and increases the likelihood of erroneous findings of statistical significance (Legendre and Legendre 1998). This has been observed for tests of normality (Dutilleul and Legendre 1992), analysis of variance (Legendre et al. 1990), and linear regression (Cliff and Ord 1981). However, Legendre et al. (2002) have shown that tests of significance for correlation and regression coefficients were valid unless both the response and predictor variables were spatially autocorrelated.

I used two approaches to test for the presence of spatial autocorrelation. For environmental variables and derived vegetation variables (metrics), spatial autocorrelation was evaluated for each factor independently. Two statistics, Moran's $I$ and Geary's $c$, were calculated using Rookcase software (Sawada 1999). These statistics are sensitive to departures from normality, and data were transformed as needed as previously described. Distances between sites were calculated from site coordinates projected in Euclidean space (Montana State Plane, 1983 North American Datum). Inter-site distances were divided into 10 classes and values for $I$ and $c$ were calculated for each class. The number of distance classes was chosen using Sturge's rule based on 30 samples and 435 pairwise comparisons (number of classes $\left.=1+3.3 \log _{10}(435)=9.7\right)($ Legendre and Legendre 1998). The significance of correlation coefficients was tested using a Monte Carlo randomization procedure with 10,000 iterations. Because the significance of coefficients was tested multiple times (once for each distance class), significance levels were adjusted with a Bonferroni correction. As the study area was relatively environmentally homogenous, second-order stationarity was assumed.

Spatial structure of the entire vegetation community was examined with a multivariate Mantel correlogram. Using the method described by Legendre and Legendre (1998), based on Oden and Sokal (1986), standardized Mantel statistics were calculated for a multivariate species distance matrix (calculated with the Kulczynski distance measure) and model matrix based on inter-site distances. Mantel statistics were calculated for each distance class and significance values were calculated by Monte Carlo permutations with 9,999 iterations using PC-ORD. Because of multiple testing, significance values were corrected with a Bonferroni procedure. 


\section{RESULTS}

\section{Human Disturbance Gradient}

The composite disturbance gradient was calculated from a PCA of four variables: AUM, amount bare ground, bank stability, and browse intensity. The first principal component explained $58.8 \%$ of the variation in the data. It was considered interpretable as it explained more variation in the data than expected by chance. Subsequent principal components did not meet this criterion. The component was rescaled so that it ranged between $[0,1]$, with the least disturbed site scoring 0 and the most disturbed site scoring 1 , and was used to represent a composite human disturbance gradient for metric development. Table 3 shows the contributions of the original variables to the composite disturbance index.

A PCA including road density was also run. It was rejected in favor of the four variable model because the addition of road density weakened the interpretability of the first principal component (component explained $46.9 \%$ of the variation, not much more than that expected by chance) while road density explained less than $1 \%$ of the variation of the component.

Table 3. Contribution of individual disturbance factors to a composite disturbance measure extracted by principal components analysis.

\begin{tabular}{lc}
\hline & $\begin{array}{c}\text { Variance Explained } \\
\text { Factor }\end{array}$ \\
\hline AUM & 0.223 \\
bare ground & 0.346 \\
bank stability & 0.252 \\
browse intensity & 0.179 \\
\hline
\end{tabular}

Measures of pug and hummock density were not included in the composite human disturbance gradient. The relationship of these measures to grazing intensity appeared to be confounded by physical characteristics of the site, as the extent of pugging and hummocking is controlled to some extent by soil texture and geomorphology. Sites with finer texture soils and depositional surfaces at lower elevations relative to bankfull discharge will likely be more susceptible to pugging and hummocking development. Although the relationship between pugging and hummocking and soil texture is only anecdotal for this dataset, there was a significant correlation between the elevation of the greenline relative to bankfull discharge and hummock density $\left(\mathrm{r}_{\mathrm{s}}=-0.42, P=0.02\right)$ and mean hummock depth $\left(r_{\mathrm{s}}=-0.42, P=0.02\right)$ and a weak correlation between greenline elevation and pug density $\left(\mathrm{r}_{\mathrm{s}}=-0.34, P=0.07\right)$.

The composite disturbance gradient and PFC categories were positively associated, both for all sites $\left(\mathrm{F}_{2,27}=9.81, P=0.0006\right)$ and BLM sites $\left(\mathrm{F}_{2}\right.$, $\left.{ }_{20}=11.81, P=0.0004\right)$. However, while composite disturbance scores were significantly different between functioning and functioning at risk categories (all sites, $P=0.003$; BLM sites, $P=$ $0.001)$ and between functioning and nonfunctioning categories (all sites, $P=0.002$; BLM sites, $P=$ $0.001)$, composite disturbance scores were not different between functioning at risk and nonfunctioning categories (all sites, $P=0.81$; BLM sites, $P=0.93$ ) (Figure 3, results from all sites analysis shown).

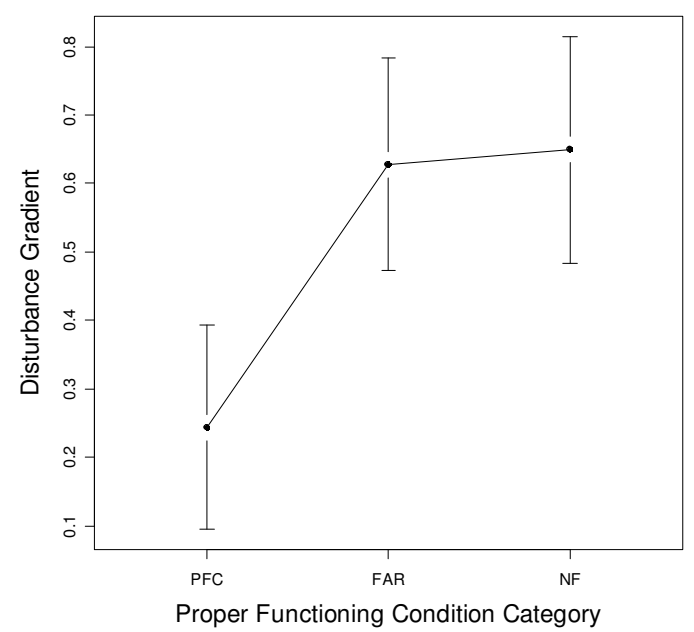

Figure 3. Graphical representation of the relationship between PFC categories and the composite disturbance gradient. Points are disturbance gradient means within PFC categories; error bars are $95 \%$ confidence intervals. PFC categories are proper functioning condition (PFC), functioning at risk (FAR), and nonfunctioning (NF); higher disturbance gradient scores reflect greater disturbance. 


\section{Metrics}

Of the 27 candidate metrics evaluated, eight were selected for inclusion in the VIBI. Five metrics were removed for failing to discriminate between least and most disturbed sites, five were eliminated due to a poor relationship with the disturbance gradient, and nine were removed because of redundancies with the selected metrics. Groups of redundant metrics included relative cover of native perennials, exotic species, exotic grasses, and intolerant species; willow seedling density and cover of willow seedlings; cover of young willows and combined cover of young and seedling willows; cover-weighted mean $C$-values and cover-weighted FQAI; relative cover of hydrophytes and cover-weighted mean wetland indicator status; and relative cover of bank stabilizing species and cover-weighted mean bank stability rating. Table 4 shows the correlation of candidate metrics with the composite disturbance gradient, whether each metric was selected for inclusion in the VIBI or not, and the reason for removal of metrics not selected.

Selected metrics were the relative cover of native graminoids, relative cover of exotic species, density of willow seedlings, combined cover of willow seedlings and young willows, coverweighted FQAI, relative cover of hydrophytes, and cover-weighted mean bank stability rating.

Table 4. Candidate metrics considered for inclusion in the VIBI, whether metrics were included and reason for removal if not selected, and metric response to composite disturbance gradient as measured by the Spearman rank correlation coefficient. Poor discriminatory power refers to the lack of difference in metric values between least and most disturbed sites; poor correlation with disturbance gradient refers to metrics with weak or no correlations with the composite disturbance gradient $\left(r_{s}<0.5\right.$ for metrics with linear association; graphical evaluation for metrics with curvilinear association).

\begin{tabular}{|c|c|c|}
\hline Metric & Selected/reason for removal & $\begin{array}{l}\text { Response to distur- } \\
\text { bance gradient }\left(r_{s}\right)\end{array}$ \\
\hline relative cover of native perennials & redundant & -0.69 \\
\hline relative cover of native graminoids & selected & -0.59 \\
\hline$<=$ & $\begin{array}{c}\text { poor correlation with disturbance gradi- } \\
\text { ent }\end{array}$ & -0.48 \\
\hline relative cover of exotic species & selected & 0.70 \\
\hline$P=$ tive cover of ex otic grasses & redundant & 0.56 \\
\hline relative cover of annuals/biennials & selected & 0.45 \\
\hline willow seedling den sity & selected & -0.50 \\
\hline absolute cover of willow seedlings & redundant & -0.52 \\
\hline absolute cover of young willows & redundant & -0.39 \\
\hline $\begin{array}{l}\text { combined absolute cover of young and seedling } \\
\text { willows }\end{array}$ & selected & -0.44 \\
\hline absolute cover of willows & poor discriminatory power & -0.13 \\
\hline willow age distribution & $\begin{array}{l}\text { poor correlation with disturbance gradi- } \\
\text { ent }\end{array}$ & -0.42 \\
\hline Shannon diversity index & poor discriminatory power & -0.15 \\
\hline Simpson diversity index & poor discriminatory power & -0.18 \\
\hline mean $C$-value & poor discriminatory power & -0.08 \\
\hline FQA I & $\begin{array}{c}\text { poor correlation with disturbance gradi- } \\
\text { ent }\end{array}$ & -0.34 \\
\hline mean $C$-value (including exotic species) & poor discriminatory power & -0.27 \\
\hline FQAI (including exotic species) & $\begin{array}{l}\text { poor correlation with disturbance gradi- } \\
\text { ent }\end{array}$ & -0.38 \\
\hline mean cover-weighted $C$-value & redundant & -0.59 \\
\hline cover-weighted FQAI & & -0.59 \\
\hline $\begin{array}{l}\text { relative cover of disturbance tolerant species }(C \leq \\
\text { 2) }\end{array}$ & redundant & 0.65 \\
\hline $\begin{array}{l}\text { relative cover of disturbance intolerant species }(C \geq \\
\text { 6) }\end{array}$ & $\begin{array}{c}\text { poor correlation with disturbance gradi- } \\
\text { ent }\end{array}$ & -0.39 \\
\hline relative cover of hydrophytes & selected & -0.60 \\
\hline relative cover of upland species & redundant & 0.32 \\
\hline cover-weighted mean wetland indicator status & redundant & -0.58 \\
\hline relative cover of bank stabilizing species & redundant & -0.54 \\
\hline cover-weighted mean bank stability rating & selected & -0.57 \\
\hline
\end{tabular}


Formulas used to compute selected metrics and metric values for the $95^{\text {th }}$ or $5^{\text {th }}$ percentiles are shown in Table 5; Figure 4 (facing pages) displays the discriminatory power and relationships of selected metrics to the composite disturbance gradient.

\section{VIBI}

The VIBI showed a highly significant response to the composite disturbance gradient $(\mathrm{VIBI}=$ $85.08-47.14 \times\left[\right.$ disturbance score], $\mathrm{F}_{1,28}=34.32$, $\mathrm{R}^{2}=0.55, P=0.000003$; Figure 5). However,

Table 5. Formulas used to score metrics. Maximum and percentile values are rounded to nearest percent (relative cover metrics), hundredth (seedling density), or tenth (cover-weighted means). $\mathrm{q}_{0.95}$ and $\mathrm{q}_{0.05}$ refer to the $95^{\text {th }}$ and $5^{\text {th }}$ percentiles, respectively.

\begin{tabular}{|c|c|c|c|c|}
\hline \multirow[b]{2}{*}{ Metric } & \multicolumn{3}{|c|}{ Value } & \multirow[b]{2}{*}{ Formula } \\
\hline & Maximum & $95^{\text {th }}$ percentile & $5^{\text {th }}$ percentile & \\
\hline relative cover of native graminoids & & 50 & & \%ngram / $\mathrm{q}_{0.95}$ \\
\hline relative cover of exotic species & 55 & & 5 & $(\max -\%$ exotic $) /\left(\max -q_{0.05}\right)$ \\
\hline relative cover of annuals/biennials ${ }^{\mathrm{a}}$ & 18 & & 0 & $(\max -\% a n n) /\left(\max -\mathrm{q}_{0.05}\right)$ \\
\hline willow seedling density $\left(\# / \mathrm{m}^{2}\right)^{\mathrm{b}}$ & & 0.58 & & sden / $\mathrm{q}_{0.95}$ \\
\hline cover seedling+young willows ${ }^{\mathrm{c}}$ & & 9 & & \%yngSalix / $q_{0.95}$ \\
\hline cover-weighted FQAI & & 30.5 & & cFQAI / q 0.95 \\
\hline relative cover of hydrophytes & & 80 & & \%hydro / $\mathrm{q}_{0.95}$ \\
\hline $\begin{array}{l}\text { cover-weighted mean bank stability } \\
\text { rating }\end{array}$ & & 3.4 & & bank / q 0.95 \\
\hline
\end{tabular}

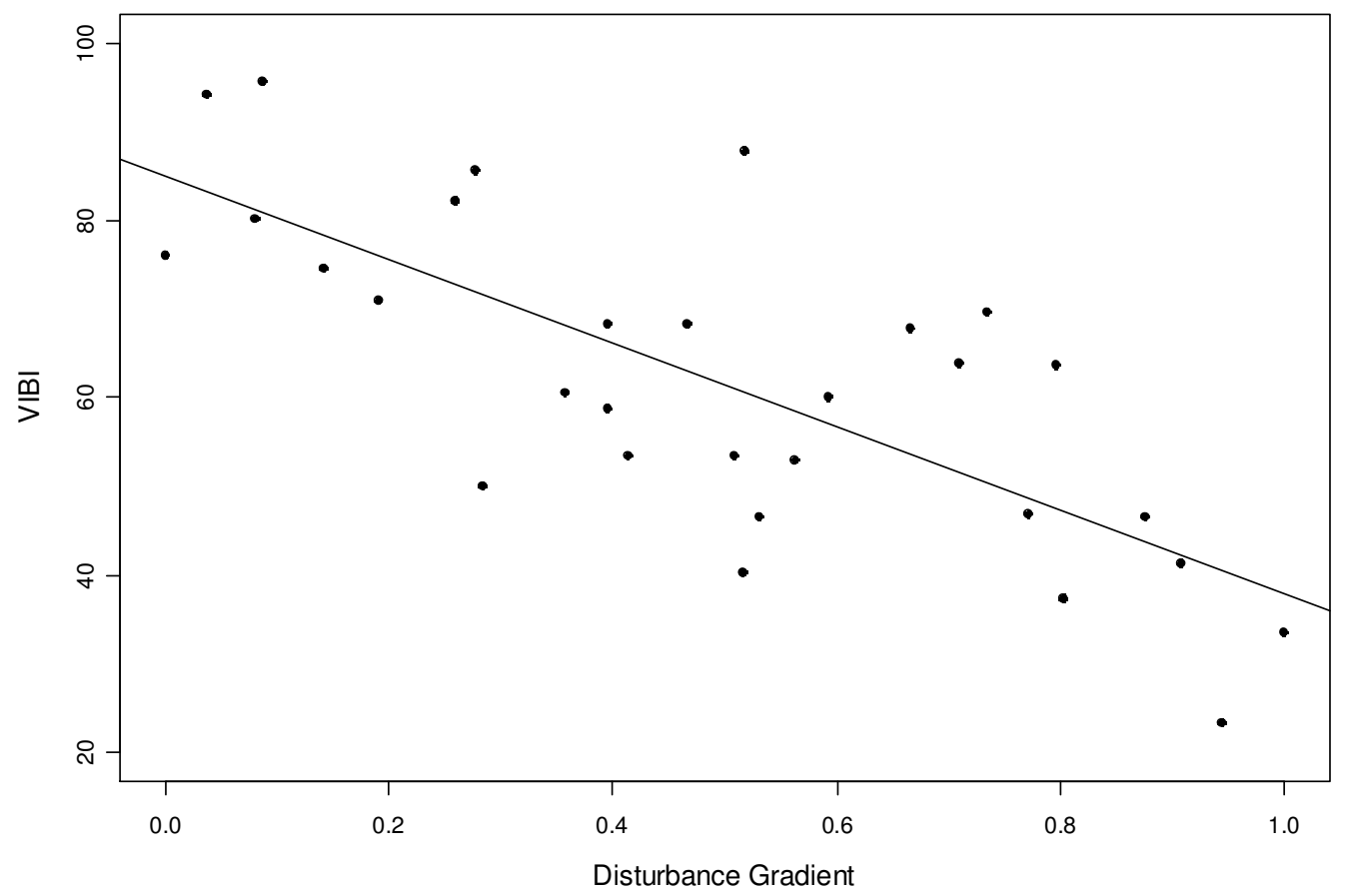

Figure 5. Scatterplot showing the relationship between the vegetation index of biotic integrity (VIBI) and a composite human disturbance gradient. Disturbance gradient ranges from 0 (least disturbed) to 1 (most disturbed); VIBI ranges from 100 (highest condition) to 0 (lowest condition). Solid line represents the fitted linear relationship when the VIBI is regressed on the disturbance gradient using ordinary least squares. 

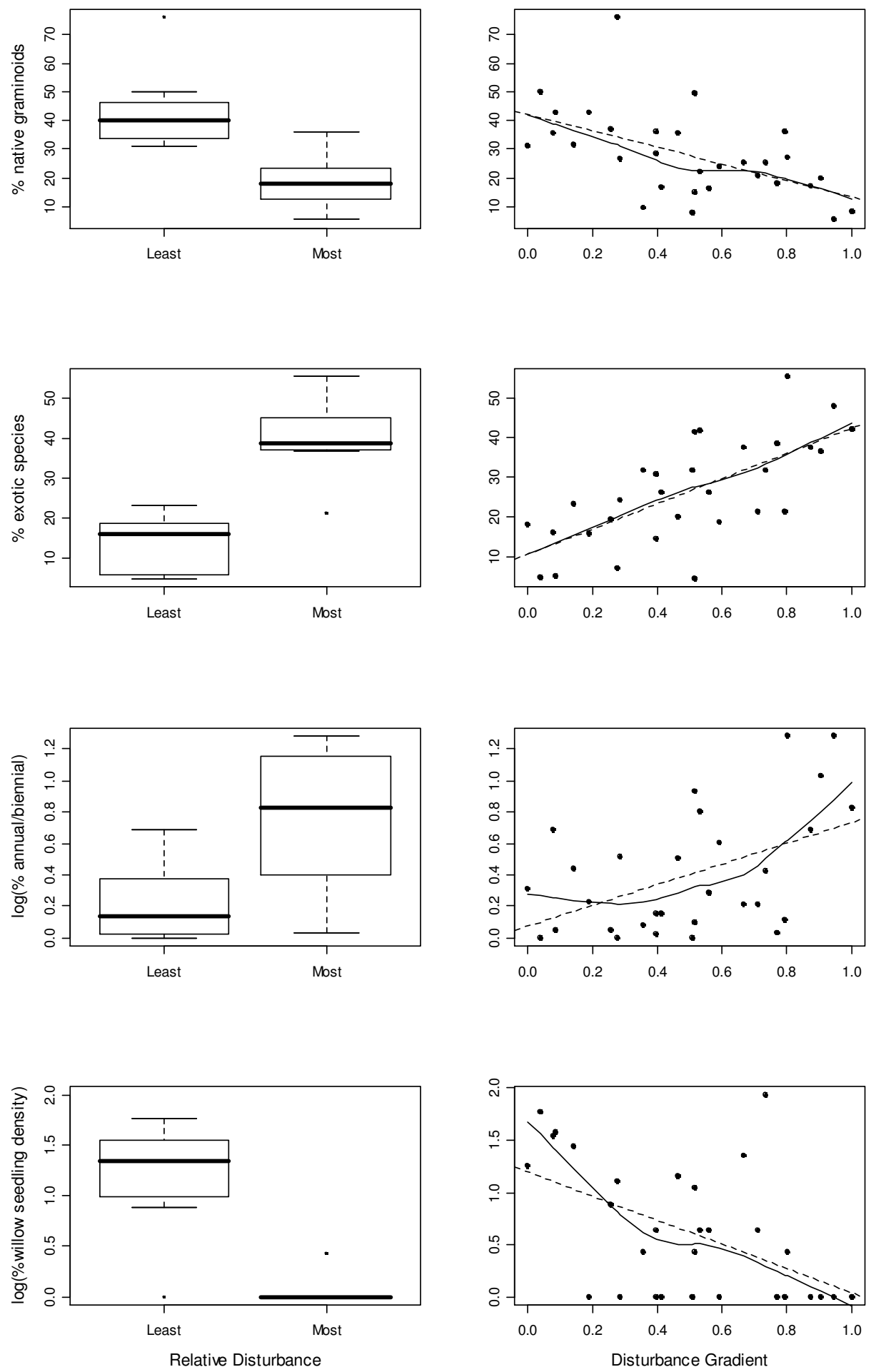

Figure 4. Discriminatory power of selected metrics and their relationship with a composite human disturbance gradient. Boxplots compare vegetation attribute values between least and most disturbed sites. Boxes show the range of the middle 50\% each metric's distribution; thick lines within boxes represent median values. Vertical lines (whiskers) show metric values within 1.5 quartiles of the box; dots show more extreme values. Dashed lines in scatterplots show the fitted linear relationship when attributes are regressed on disturbance using ordinary least squares; solid lines show a locally weighted nonparametric smoother. 

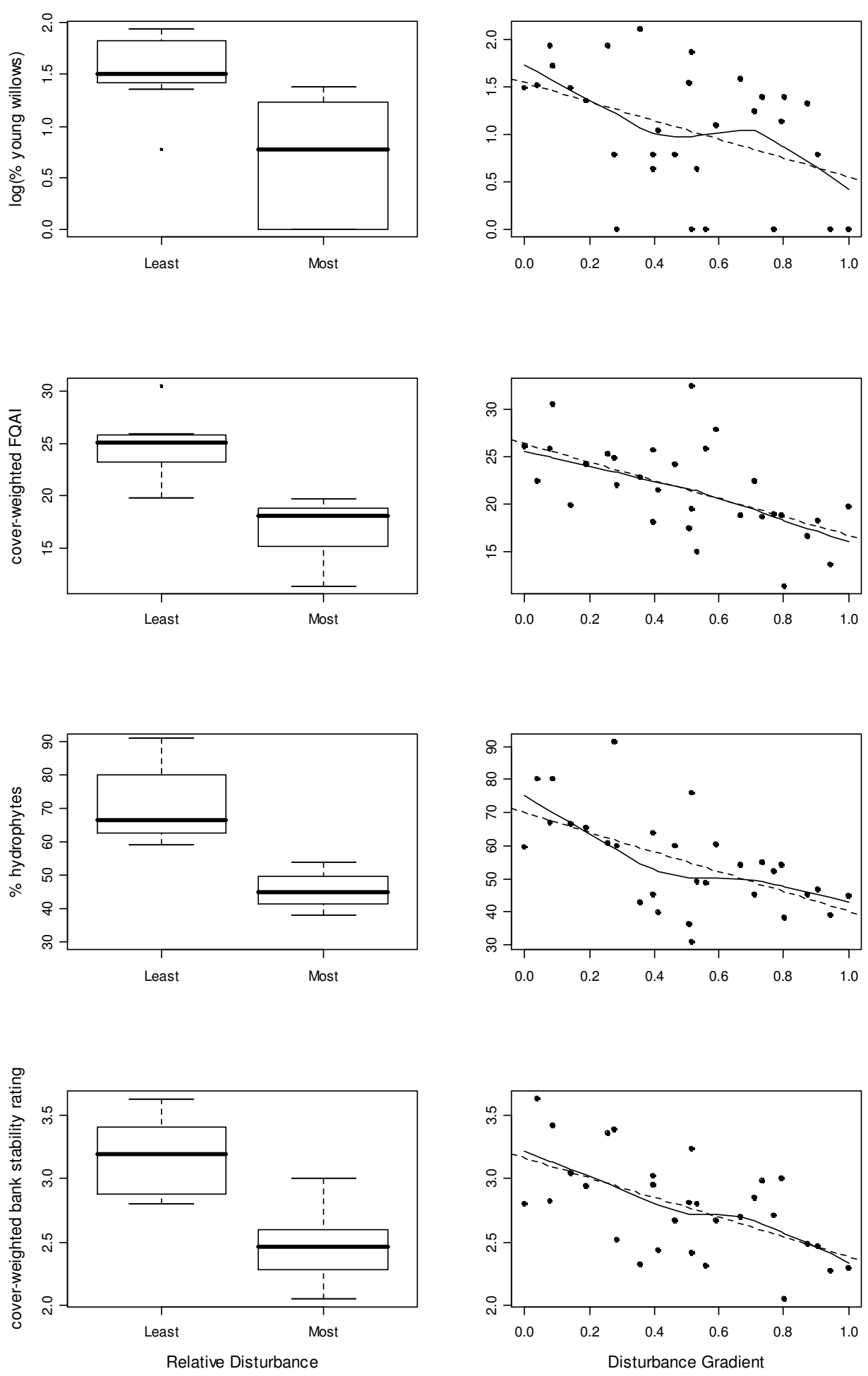

Figure 4. (Continued) 
Table 6. Accuracy assessment of VIBI scoring thresholds with regard to disturbance classes.

\begin{tabular}{lcccc}
\hline & \multicolumn{3}{c}{ Predicted disturbance class } & Actual total \\
\cline { 2 - 5 } Actual class & Least disturbed & Moderately disturbed & Most disturbed & 8 \\
\hline Least disturbed & 8 & 0 & 0 & 15 \\
Moderately disturbed & 1 & 12 & 2 & 7 \\
Most disturbed & 0 & 1 & 8 & 30 \\
Predicted total & 9 & 13 & & \\
Overall accuracy & $87 \%$ & & & \\
\hline
\end{tabular}

VIBI scores could reliably only differentiate three condition classes $\left(\mathrm{F}_{2,27}=23.09, P=0.0000001\right.$, all pairwise comparisons significant at the 0.001 level after Bonferroni correction). Overall, the VIBI was relatively robust in its ability to differentiate between these classes (Table 6). While analyses of variance of the four- and five-category partitions of the composite disturbance gradient were significant, VIBI means were not strongly differentiated among all disturbance categories. Sites with VIBI scores above 70 were considered to be reference condition (Figure 6), sites with scores from 48 to 70 were considered to be moderately impaired (Figure 7), and sites with scores below 48 were considered to be severely impaired (Figure 8). Figure 9 graphically displays VIBI scoring thresholds, condition classes, and misclassified cases. Species indicative of each condition class are shown in Table 7.

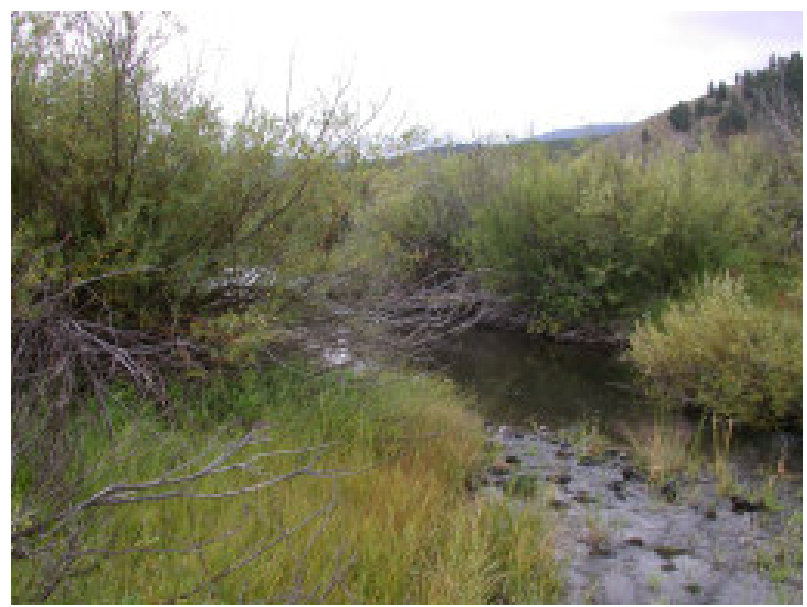

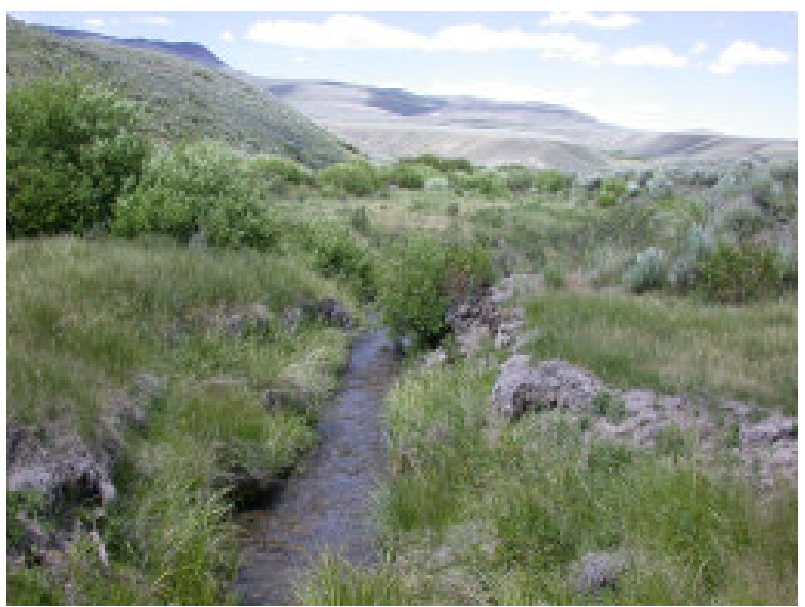

Figure 7. Moderately impaired site; channel shows evidence of past incisement but is stable.

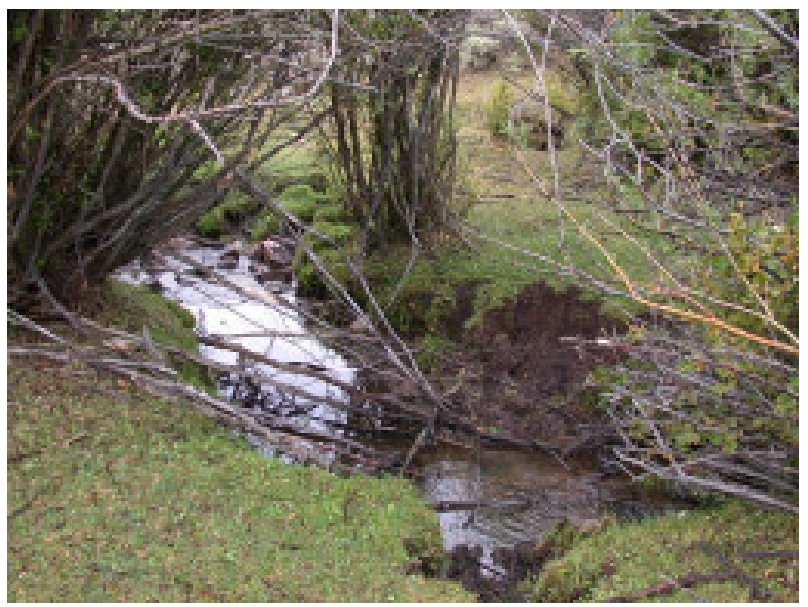

Figure 8. Severely impaired site; note incised and unstable banks.

Figure 6. Reference condition site. 

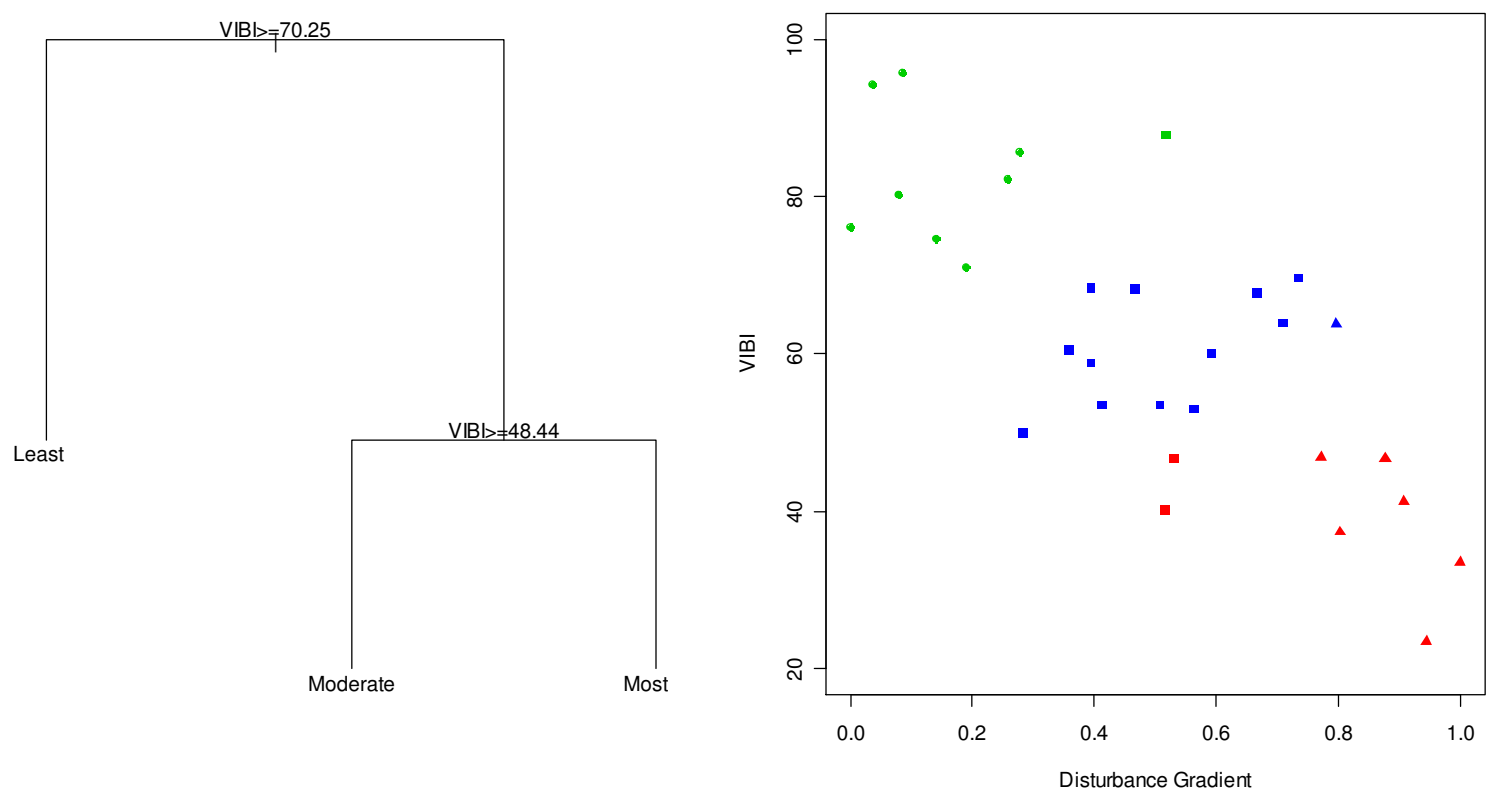

Figure 9. (A) Tree diagram showing VIBI scoring thresholds associated with disturbance categories. Least $=$ least disturbed, Moderate $=$ moderately disturbed, Most $=$ most disturbed. (B) Scatterplot of the composite disturbance gradient and VIBI. Symbols represent disturbance categores: $\bullet=$ least disturbed sites, $\mathbf{\square}=$ moderately disturbed sites, $\boldsymbol{\Delta}_{=}$most disturbed sites. Colors represent VIBI classes: green $=$reference condition, blue $=$moderately impaired, red = severely impaired.

Table 7. Species indicative of reference, moderately disturbed, and severely disturbed sites. Indicator value represents the strength of indication $(0=$ no indication, $100=$ perfect indication $)$. P-values were calculated with a Monte Carlo permutation test. Species with indicator values $>25$ and $\mathrm{P}<0.1$ are reported.

\begin{tabular}{|c|c|c|c|c|}
\hline Scientific Name & Common Name & Condition Class & $\begin{array}{c}\text { Indicator } \\
\text { Value }\end{array}$ & $\begin{array}{c}P- \\
\text { value }\end{array}$ \\
\hline Agrostis scabra & rough bentgrass & reference & 39.4 & 0.049 \\
\hline Carex aquatilis & water sedge & reference & 58.5 & 0.022 \\
\hline Carex utriculata & beaked sedge & reference & 50.3 & 0.044 \\
\hline Galium trifidum & threepetal bedstraw & reference & 46.6 & 0.073 \\
\hline Juncus ensifolius & swordleaf rush & reference & 67.4 & 0.004 \\
\hline Salix drummondiana & Drummond's willow & reference & 50.6 & 0.008 \\
\hline Iris missouriensis & Rocky Mountain iris & moderately impaired & 37.7 & 0.058 \\
\hline Maianthemum stellatum & starry false lily of the valley & moderately impaired & 47.1 & 0.057 \\
\hline Mertensia ciliata & tall fringed bluebells & moderately impaired & 39.0 & 0.063 \\
\hline Muhlenbergia richardsonis & mat muhly & moderately impaired & 37.5 & 0.088 \\
\hline Potentilla gracilis & slender cinquefoil & moderately impaired & 61.3 & 0.012 \\
\hline Pyrola asarifolia & liverleaf wintergreen & moderately impaired & 34.5 & 0.061 \\
\hline Trifolium longipes & longstalk clover & moderately impaired & 54.0 & 0.047 \\
\hline Carex nebrascensis & Nebraska sedge & severely impaired & 29.4 & 0.087 \\
\hline Cirsium vulgare & bull thistle & severely impaired & 37.5 & 0.017 \\
\hline Poa pratensis & Kentucky bluegrass & severely impaired & 46.8 & 0.011 \\
\hline Ranunculus abortivus & littleleaf buttercup & severely impaired & 50.5 & 0.036 \\
\hline Rosa woodsii & Woods' rose & severely impaired & 64.5 & 0.003 \\
\hline Trifolium repens & white clover & severely impaired & 68.4 & 0.001 \\
\hline Triglochin palustre & marsh arrowgrass & severely impaired & 28.7 & 0.089 \\
\hline
\end{tabular}




\section{Whole Community}

Relationships among sample units are graphically displayed in Figure 10, which shows the results from the NMS ordination (three-dimensional solution, stress $=12.56$, instability $<0.00001,83$ iterations). The ordination diagram shows that vegetation is differentiated along the composite disturbance gradient, as evidenced by the relatively distinct groupings of VIBI condition classes. The vegetation community was significantly correlated with the disturbance gradient $\left(\mathrm{r}_{\mathrm{M}}=0.15, P=0.02\right)$.

\section{Spatial Autocorrelation}

No significant spatial autocorrelation was observed for either environmental or vegetationderived variables at any distance class after Bonferroni corrections. Autocorrelation in the vegetation community trended from positive to negative over increasing distances; however, these results were nonsignificant after a Bonferroni correction.

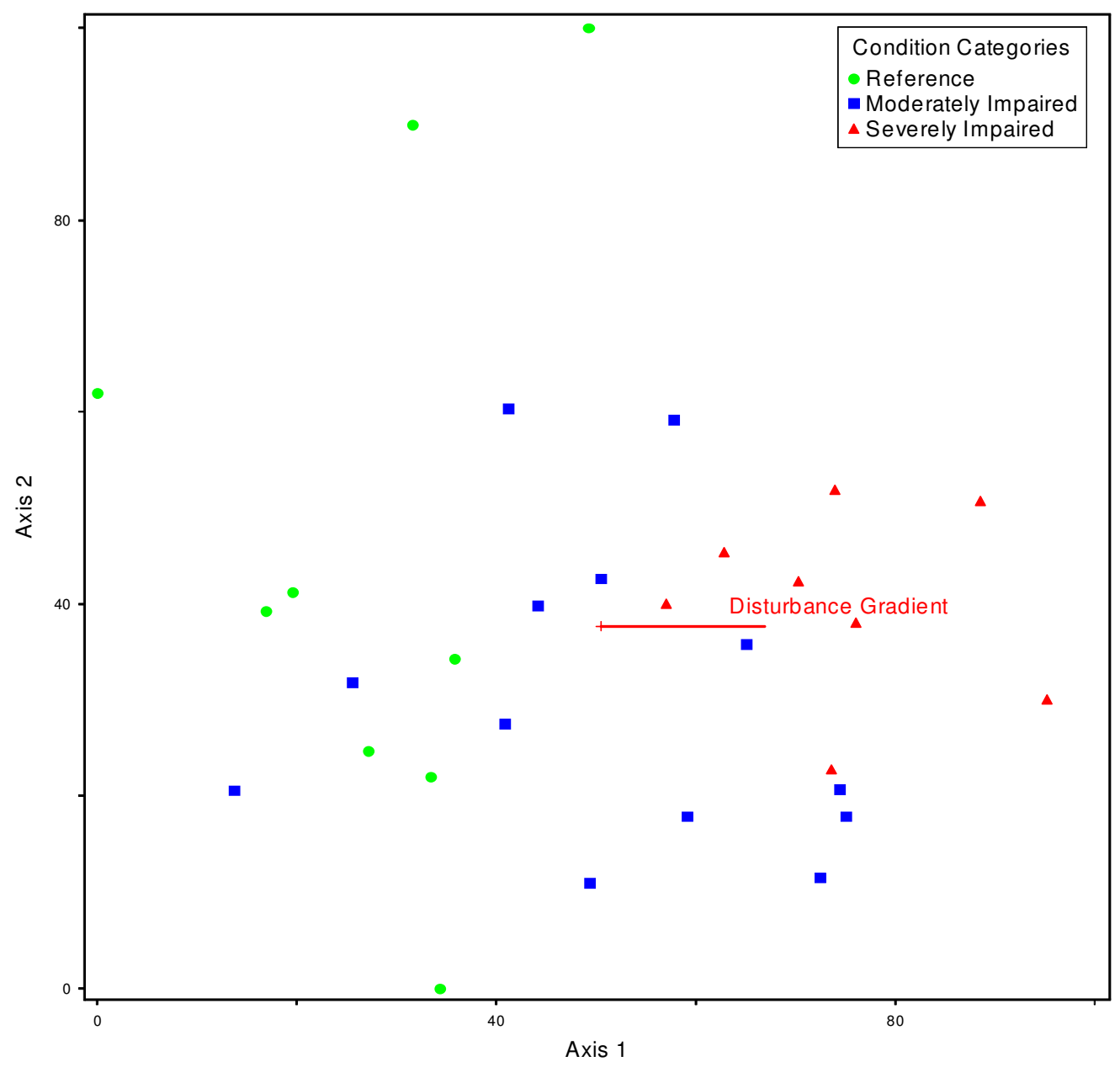

Figure 10. Graphical representation of the NMS ordination of sample reaches. Points represent aggregated species cover and composition data for each sample reach. Distance between points is proportional to dissimilarity between samples (i.e., samples with similar species composition are plotted closer together). Axis 1, which corresponds to the composite disturbance gradient, represents $20 \%$ of the variation in the data; Axis 2 accounts for $47 \%$ (total variation explained $=67 \%$ ). The vector represents the strength of the relationship between Axis 1 and the composite disturbance gradient $\left(\mathrm{R}^{2}=0.31\right)$. Condition categories refer to VIBI condition classes. 


\section{DisCUSSION}

The goal of this study was to find attributes of the riparian vegetation community that responded predictably to human disturbance and could be used to assess site condition. Eight such attributes were identified and combined into a vegetation index of biotic integrity. Overall, this multimetric index demonstrated a robust response to grazing-related stressors, and VIBI scores could be used to classify a site into one of three disturbance categories with relatively high accuracy. Within the reference domain considered - small-order montane streams able to support woody vegetation - the VIBI appears to be a good indicator of site condition. This is consistent with other multimetric vegetation studies that have found plants to be good indicators of wetland and riparian condition (DeKeyser et al. 2003, Mack 2004, Jones 2004, Ferreira et al. 2005).

Both a strength and complication of using vegetation as an indicator of site condition is the large number of species often involved. For example, 178 species of vascular plants were sampled in the course of this study, and the mean richness was $43 \pm 7$ species per site. A strength of the multimetric approach is that species are grouped by the expected similarity of their response to disturbance or stress. This makes use of redundancies in species' responses within groups and can thereby reduce the noise often generated when the response of all species is considered simultaneously. This study made use of species groups based on functionality, taxonomy, and nativity. The utility of vegetation classifications based on common attributes, adaptations, or responses of species to environmental factors, has long been recognized (Raunkiaer 1934, Grime 1977, Grime 1988, Lavorel and Garnier 2002, Pausas and Lavorel 2003). Functional groups in particular have been shown to be an effective approach to evaluating vegetation response to grazing-related disturbances (Friedel et al. 1988, McIntyre et al. 1995, Lavorel et al. 1997, Landsberg et al. 1999). In this study, the VIBI showed a much stronger response to the disturbance gradient than did the whole community analysis.

A major output of this project was the extension of the floristic quality assessment methodology to western Montana wetlands. Although not strictly a functional classification, the concept of floristic quality, which is based on the fidelity of plant species to high-integrity habitats, can be used as a broadly integrative measure of site condition. It is especially pertinent for measuring humanassociated stresses, as the tolerance of plant species to anthropogenic disturbance is an implicit criterion in the assignment of $C$-values. The utility of the floristic quality assessment index as a vegetation metric has been demonstrated in diverse wetland settings (Lopez and Fennessy 2002, DeKeyser et al. 2003, Cohen et al. 2004).

The FQAI has been criticized for the subjective assignment of $C$-values. In a study of prairie potholes using $C$-values assigned by expert opinion for the Dakotas (Northern Great Plains Floristic Quality Assessment Panel 2001), Mushet et al. (2002) found that subjectively assigned $C$-values were good indicators of species response and gave comparable results to $C$-values that had been objectively derived. Although the $C$-values used in this study have not been independently verified, they are likely to be similarly robust.

One surprising finding was the relatively poor performance of the floristic quality assessment index, at least as traditionally calculated. The FQAI is usually computed based on species presence/absence data, and this approach has been found to be a good indicator of site condition (Lopez and Fennessy 2002, Cohen et al. 2004). However, in this study, the species richness-based FQAI exhibited a weak correlation with disturbance. Including exotic species in the richness-based FQAI provided a marginal improvement. In contrast, the FQAI weighted by each species' relative cover was strongly correlated with the disturbance gradient. This is in contrast to Cohen et al. (2004) who found no improvement in FQAI performance when using frequency-weighted abundance values. The improvement in FQAI performance with coverweighted values in this study may be due in part to the increased dominance of a relatively few exotic species with low $C$-values in disturbed sites. These species include Kentucky bluegrass, redtop (Agrostis gigantea Roth), white clover (Trifolium 
repens L.), and common dandelion (Taraxacum officinale G.H. Weber ex Wiggers).

Although in this study the FQAI was used as a component in a multimetric index, floristic quality assessments should have broader applicability. In assigning $C$-values, the expert panel was not limited to the species sampled in this study but considered all species likely to occur in western Montana wetlands (the species list was taken from Lesica and Husby (2001, Appendix A)). Thus, the FQAI and related measures of floristic quality can be tested and applied as a stand-alone indicator of site condition to all wetland types in western Montana, not just the limited subset considered here. Further testing should be done to compare the relative utility of the presence-absence and cover-weighted formulations of the FQAI.

\section{Recommendations for Future Improvements}

An important next step is to validate the VIBI and to expand its applicability. This study examined vegetation response to a single, albeit complex, stressor. The VIBI should be validated at additional environmentally similar sites where grazing is the primary human stressor. However, to be broadly applicable, the VIBI will need to be generalized so that it is responsive to other anthropogenic stressors, especially those that modify hydrology. Some applicability of the VIBI as formulated here should be expected, as one of the effects of overgrazing can be bank erosion and stream channel downcutting, which can affect hydrology and make a site "drier." Functionally, there may be some overlap between grazinginduced stresses on the vegetation community and other stressors that cause hydrologic alterations. Several of the metrics developed here, including willow seedling density, absolute cover of willow seedlings and young willows, and relative cover of hydrophytes, should also be responsive to hydrologic stressors.

The site selection procedure used in this study could also be improved. Sites were initially selected based on proper functioning condition assessments. PFC categories, which were assumed to be indicative of general site condition, were used to establish a broad disturbance gradient for sampling purposes. However, PFC assessments may not adequately differentiate between moderately and highly disturbed sites, at least when grazing is the primary stressor. This is evidenced by the lack of difference in mean PCAderived disturbance scores between the functioning at risk and nonfunctioning categories. This lack of association may reflect in part the different purposes of these measures of disturbance: the composite disturbance gradient was constructed by finding linear combinations of variables that were expected to measure different aspects of grazingassociated stresses, while the PFC is a more general method to evaluate site condition.

Another aspect of the site selection process should be reconsidered: in defining the site selection criteria for this study, the sampling universe was restricted to sites able to support tall woody vegetation (i.e., willows). Site potential was verified by either previous BLM surveys, which characterized sites by Hansen et al.'s (1995) vegetation community classification or by review of U.S. Geological Survey digital orthophoto imagery. This was done to focus on the most typical stream reaches (which do support woody vegetation) and to reduce environmental heterogeneity by excluding forested, sagebrush, or herbaceous-dominated stream reaches (i.e., sedge meadows). Although reducing environmental heterogeneity is an important design consideration when developing multimetric indices (Teels and Adamus 2002), an unfortunate result of this stratification was the potential undersampling of extremely disturbed sites where grazing had completely removed woody cover. All the sites sampled in this study, even the most heavily disturbed, supported willow cover, although at heavily disturbed sites this cover was usually exclusively provided by mature or senescent willows.

Another improvement would be to develop a model- or rule-based scoring method to measure a site's level of disturbance. The PCA-based method employed in this study had the benefit of providing a quantitative and objective measure of site disturbance, and it was a good first step to understand the relative importance of and interactions between the measured disturbance variables. However, a limitation to this approach is 
that the specific results are idiosyncratic to the collected dataset. A next step would either be to model the composite disturbance gradient (e.g., generalize the results of the PCA by finding explanatory equations) or to develop a rule-based procedure. Lopez and Fennessy (2002) used a rule-based approach to describe wetland disturbance: wetlands were ordered into one of 24 categories based on buffer conditions and presence of hydrologic modifications. Ohio EPA used their rapid assessment method as a measure of site disturbance (Mack et al. 2000). (This last approach would be somewhat circular, as the VIBI is meant to be used to validate DEQ's rapid assessment.) Developing a more generalized disturbance measure will become more of an issue as the VIBI's reference domain broadens to include greater environmental and anthropogenic heterogeneity.

A parallel issue is to limit disturbance factors to variables that are measurable at all sites. For example, three of the disturbance factors used here, amount bare ground, bank stability, and browse intensity, were measured on-site. The fourth, livestock use (AUM), was readily available only because sites were sampled on public land.
Therefore, AUM is not likely to be easily generalized and should probably be removed from future studies.

Finally, there is the question of improving the broader utility of the VIBI. As the VIBI is sufficiently validated (and possibly modified), it will become a useful tool to assess riparian area condition and will provide validation for rapid assessments. However, because many of the metrics require the entire vegetation community to be enumerated, the VIBI requires extensive botanical expertise and time. An ongoing goal in refining the VIBI should be to use more easily measured metrics that can perhaps be ultimately incorporated into the rapid assessment method. Current examples are willow seedling density and cover of young and seedling willows. Cohen et al. (2005) used classification and regression trees to identify indicator species for different wetland condition categories, thereby lessening the botanical expertise needed to assess wetland condition. Likewise, the indicator species recognized here may form the basis of identifying key plant species that are consistently associated with certain levels of disturbance. 


\section{Literature Cited}

Abernathy, B. and I. D. Rutherfurd. 2001. The distribution and strength of riparian tree roots in relation to riverbank reinforcement. Hydrological Processes 15:63-79.

Andreas, B. K., J. J. Mack, and J. S. McCormac. 2004. Floristic quality assessment index (FQAI) for vascular plants and mosses for the State of Ohio. Ohio Environmental Protection Agency, Division of Surface Water, Wetland Ecology Group, Columbus, Ohio.

Apfelbeck, R. S. 2001. Development of biocriteria for wetlands in Montana. Pages 141-166 in R. B. Rader, D. P. Batzer, and S. A. Wissinger, editors. Bioassessment and management of North American freshwater wetlands. John Wiley \& Sons, Inc., New York, New York.

Barbour, M. T., J. Gerritsen, G. E. Griffith, R. Frydenborg, E. McCarron, J. S. White, and M. L. Bastian. 1996. A framework for biological criteria for Florida streams using benthic macroinvertebrates. Journal of the North American Benthological Society 15:185-211.

Barbour, M. T., J. Gerritsen, B. D. Snyder, and J. B. Stribling. 1999. Rapid bioassessment protocols for use in streams and wadeable rivers: periphyton, benthic macroinvertebrates and fish, Second Edition. EPA 841-B-99-002, U.S. Environmental Protection Agency, Office of Water, Washington, D.C.

Bengeyfield, P. 1999. Analysis of reference reach data and the prediction of stream types. Pages 245-254 in D. S. Olsen and J. P. Potyondy, editors. Proceedings of the Specialty Conference on Wildland Hydrology (Bozeman, Montana). American Water Resources Association, Hendon, Virginia.

Blocksom, K. A. 2003. A performance comparison of metric scoring methods for a multimetric index for mid-Atlantic highland streams. Environmental Management 31:670-682.

Blocksom, K. A., J. P. Kurtenbach, D. J. Klemm, F. A. Fulk, and S. M. Cormier. 2002. Development and evaluation of the lake macroinvertebrate integrity index (LMII) for New Jersey lakes and reservoirs. Environmental Monitoring and Assessment 77:311-333.
Borth, C. S. 1998. Effects of land use on vegetation in glaciated depressional wetlands in western Montana. Masters Thesis. Montana State University, Bozeman, Montana.

Box, G. E. P. and D. R. Cox. 1964. An analysis of transformations. Journal of the Royal Statistical Society B 26:211-243.

Breiman, L., J. H. Friedman, R. A. Olshen, and C. J. Stone. 1984. Classification and regression trees. Chapman \& Hall, New York, NewYork.

Brinson, M. M., B. L. Swift, R. C. Plantico, and J. S. Barclay. 1981. Riparian ecosystems: their ecology and status. U.S. Fish and Wildlife Service Biological Report 81, U.S. Government Printing Office, Washington, D.C.

Brookshire, E. N. J., J. B. Kauffman, D. Lytjen, and N. Otting. 2002. Cumulative effects of wild ungulate and livestock herbivory on riparian willows. Oecologia 132:559-566.

Bryce, S. A., R. M. Hughes, and P. R. Kaufmann. 2002. Development of a bird integrity index: using bird assemblages as indicators of riparian condition. Environmental Management 30:294310.

Clary, W. P. 1999. Stream channel and vegetation response to late spring cattle grazing. Journal of Range Management 52:218-227.

Clary, W. P. and J. W. Kinney. 2002. Streambank and vegetation response to simulated cattle grazing. Wetlands 22:139-148.

Cliff, A. D. and J. K. Ord. 1981. Spatial processes - models and applications. Pion, London.

Cohen, M. J., S. Carstenn, and C. R. Lane. 2004. Floristic quality indices for biotic assessment of depressional marsh condition in Florida. Ecology 14:784-794.

Cohen, M. J., C. R. Lane, K. C. Reiss, J. A. Surdick, E. Bardi, and M. T. Brown. 2005. Vegetation based classification trees for rapid assessment of isolated wetland condition. Ecological Indicators 5:189-206.

Coles-Ritchie, M., A. Kelly, and R. Henderson. 2004. Effectiveness monitoring for streams and riparian areas within the upper Columbia River basin: sampling protocol - vegetation parameters. U.S. Department of Agriculture, Forest Service, PIBO Effectiveness Monitoring Program, Logan, Utah. 
Cooper, S. V. 2004. Annotated bibliography of quantitative sampling methods for watershed assessment. Montana Natural Heritage Program, Helena, Montana.

Crowe, E. and R. Clausnitzer. 1997. Mid-montane wetland plant associations of the Malheur, Umatilla, and Wallowa-Whitman National Forests. Technical Paper R6-NR-ECOL-TP22-97, USDA Forest Service, Pacific Northwest Region.

Dahl, T. E. 1990. Wetland losses in the United States 1780's to 1980's. U.S. Department of Interior, Fish and Wildlife Service, Washington, D.C.

Danielson, T. J. 2002. Methods for evaluating wetland condition: introduction to wetland biological assessment. EPA-822-R-02-014, Office of Water, U.S. Environmental Protection Agency, Washington, D.C.

Daubenmire, R. F. 1959. A canopy-coverage method of vegetation analysis. Northwest Science 33:43-64.

DeKeyser, E. S., D. R. Kirby, and M. J. Ell. 2003. An index of plant community integrity: development of the methodology for assessing prairie wetland plant communities. Ecological Indicators 3:119-133.

Dufrêne, M. and P. Legendre. 1997. Species assemblages and indicator species: the need for a flexible asymmetrical approach. Ecological Monographs 67:345-366.

Dutilleul, P. and P. Legendre. 1992. Lack of robustness in two tests of normality against autocorrelation in sample data. Journal of Statistical Computation and Simulation 42:7991.

Fennessy, S., M. Gernes, J. Mack, and D. H. Wardrop. 2002. Methods for evaluating wetland condition: using vegetation to assess environmental conditions in wetlands. EPA822-R-02-020, Office of Water, U.S. Environmental Protection Agency, Washington, D.C.

Ferreira, M. T., P. M. Rodríguez-González, F. C. Aguiar, and A. Albuquerque. 2005. Assessing biotic integrity in Iberian rivers: development of a multimetric plant index. Ecological Indicators 5:137-149.
Finch, D. M. and L. F. Ruggiero. 1993. Wildlife and biological diversity in the Rocky Mountains and northern Great Plains. Natural Areas Journal 13:191-203.

Flenniken, M., R. R. McEldowney, W. C. Leininger, G. W. Frasier, and M. J. Trlica. 2001. Hydrologic responses of a montane riparian ecosystem following cattle use. Journal of Range Management 54:567-574.

Fore, L. S. and C. Grafe. 2002. Using diatoms to assess the biological condition of large rivers in Idaho (USA). Freshwater Biology 47:20152037.

Fox, J. 2005. car: Companion to applied regression package for R, version 1.0-16. Available at http://cran.r-project.org/.

Francis, C. M., M. J. W. Austen, J. M. Bowles, and W. B. Draper. 2000. Assessing floristic quality in southern Ontario woodlands. Natural Areas Journal 20:66-77.

Friedel, M. H., G. N. Bastin, and G. F. Griffin. 1988. Range assessment and monitoring in arid lands: the derivation of functional groups to simplify vegetation data. Journal of Environmental Management 27:85-97.

Frontier, S. 1976. Étude de la décroissance des valeurs propres dans une analyse en composantes principales: comparaison avec le modèle du bâton brisé. Journal of Experimental Marine Biology and Ecology 25:67-75.

Green, D. M. and J. B. Kauffman. 1995. Succession and livestock grazing in a northeastern Oregon riparian ecosystem. Journal of Range Management 48:307-313.

Grime, J. P. 1977. Evidence for the existence of three primary strategies in plants and its relevance to ecological and evolutionary theory. American Naturalist 111:1169-1194.

Grime, J. P. 1988. The C-S-R model of primary plant strategies - origins, implications and tests. Pages 371-393 in L. D. Gottlieb and S. K. Jain, editors. Plant evolutionary biology. Chapman \& Hall, London.

Hansen, P. L., R. D. Pfister, K. Boggs, B. J. Cook, J. Joy, and D. K. Hinckley. 1995. Classification and management of Montana's riparian and wetland sites. Miscellaneous Publication No. 54, Montana Forest and Conservation Experiment Station, School of Forestry, The University of Montana, Missoula, Montana. 
Helgen, J. C. and M. C. Gernes. 2001. Monitoring the condition of wetlands: indexes of biological integrity using invertebrates and vegetation. Pages 167-185 in R. B. Rader, D. P. Batzer, and S. A. Wissinger, editors. Bioassessment and management of North American freshwater wetlands. John Wiley \& Sons, Inc., New York, New York.

Hughes, R. M., P. R. Kaufmann, A. T. Herlihy, T. M. Kincaid, L. Reynolds, and D. P. Larsen. 1998. A process for developing and evaluating indices of fish assemblage integrity. Canadian Journal Fisheries and Aquatic Sciences 55:1618-1631.

Hyndman, R. J. and Y. Fan. 1996. Sample quantiles in statistical packages. American Statistician 50:361-365.

Ihaka, R. and R. Gentleman. 1996. R: a language for data analysis and graphics. Journal of Computational and Graphical Statistics 5:299314.

Jackson, D. A. 1993. Stopping rules in principal components analysis: a comparison of heuristical and statistical approaches. Ecology 74:2204-2214.

Jones, W. M. 2004. Using vegetation to assess wetland condition: a multimetric approach for temporarily and seasonally flooded depressional wetlands and herbaceous-dominated intermittent and ephemeral riverine wetlands in the northwestern glaciated plains ecoregion, Montana. Report to the Montana Department of Environmental Quality and U.S. Environmental Protection Agency, Montana Natural Heritage Program, Helena, Montana.

Karr, J. R. 1981. Assessment of biotic integrity using fish communities. Fisheries 6:21-27.

Karr, J. R. and E. W. Chu. 1999. Restoring life in running waters: better biological monitoring. Island Press, Washington, D.C.

Kauffman, J. B. and W. C. Krueger. 1984. Livestock impacts on riparian ecosystems and streamside management implications... a review. Journal of Range Management 37:430438.

Kauffman, J. B., W. C. Krueger, and M. Vavra. 1983a. Effects of late season cattle grazing on riparian plant communities. Journal of Range Management 36:685-691.
Kauffman, J. B., W. C. Krueger, and M. Vavra. 1983b. Impact of cattle on streambanks in northeastern Oregon. Journal of Range Management 36:683-685.

Kauffman, J. B., A. S. Thorpe, and E. N. J. Brookshire. 2004. Livestock exclusion and belowground ecosystem responses in riparian meadows of eastern Oregon. Ecological Applications 14:1671-1679.

Keddy, P. A. 2000. Wetland ecology: principles and conservation. Cambridge University Press, Cambridge.

Keigley, R. B. and M. R. Frisina. 1998. Browse evaluation by analysis of growth form. Volume 1 , methods for evaluating condition and trend. Montana Department of Fish, Wildlife \& Parks, Helena, Montana.

Kimberling, D. N., J. R. Karr, and L. S. Fore. 2001. Measuring human disturbance using terrestrial invertebrates in the shrub-steppe of eastern Washington (USA). Ecological Indicators 1:63-81.

King, R. S., M. E. Baker, D. F. Whigham, D. E. Weller, T. E. Jordan, P. F. Kazyak, and M. K. Hurd. 2005. Spatial considerations for linking watershed land cover to ecological indicators in streams. Ecological Applications 15:137-153.

Klemm, D. J., K. A. Blocksom, F. A. Fulk, A. T. Herlihy, R. M. Hughes, P. R. Kaufmann, D. V. Peck, J. L. Stoddard, W. T. Theony, and M. B. Griffith. 2003. Development and evaluation of a macroinvertebrate biotic integrity index (MBII) for regionally assessing mid-Atlantic highland streams. Environmental Management 31:656-669.

Kruskal, J. B. 1964. Nonmetric multidimensional scaling: a numerical method. Psychometrika 29:115-129.

Landsberg, J., S. Lavorel, and J. Stol. 1999. Grazing response groups among understorey plants in arid rangelands. Journal of Vegetation Science 10:683-696.

Lavorel, S. and E. Garnier. 2002. Predicting changes in community composition and ecosystem functioning from plant traits: revisiting the Holy Grail. Functional Ecology 16:545-556. 
Lavorel, S., S. McIntyre, J. Landsberg, and T. D. A. Forbes. 1997. Plant functional classifications: from general groups to specific groups based on response to disturbance. Trends in Ecology and Evolution 12:474-478.

Legendre, P. 1993. Spatial autocorrelation: trouble or new paradigm? Ecology 74:1659-1673.

Legendre, P., M. R. T. Dale, M.-J. Fortin, J. Gurevitch, M. Hohn, and D. Myers. 2002. The consequences of spatial structure for the design and analysis of ecological field surveys. Ecography 25:601-615.

Legendre, P. and L. Legendre. 1998. Numerical ecology, 2nd English edition. Elsevier Scientific Publishing Company, Amsterdam, The Netherlands.

Legendre, P., N. L. Oden, R. R. Sokal, A. Vaudor, and J. Kim. 1990. Approximate analysis of variance of spatially autocorrelated regional data. Journal of Classification 7:53-75.

Lesica, P. and P. Husby. 2001. Field guide to Montana's wetland vascular plants. Montana Wetlands Trust, Helena, Montana.

Levene, H. 1960. Robust tests for equality of variance. Pages 278-292 in I. Olkin, editor. Contributions to probability and statistics. Stanford University Press, Palo Alto, California.

Lonn, J. D., B. Skipp, E. T. Ruppel, S. U. Janecke, W. J. Perry, J. W. Sears, M. J. Bartholomew, M. C. Stickney, W. J. Fritz, H. A. Hurlow, and R. C. Thomas. 2000. Preliminary geologic map of the Lima 30' x 60' quadrangle, southwest Montana. Open File Report MBMG 408, Montana Bureau of Mines and Geology, Butte, Montana.

Lopez, R. D. and M. S. Fennessy. 2002. Testing the floristic quality assessment index as an indicator of wetland condition. Ecological Applications 12:487-97.

Mack, J. J., M. Micacchion, L. D. Augusta, and G. R. Sablak. 2000. Vegetation indices of biotic integrity (VIBI) for wetlands and calibration of the Ohio rapid assessment method for wetlands, v. 5.0. Ohio Environmental Protection Agency, Division of Surface Water, Wetland Ecology Unit, Columbus, Ohio.
Mack, J. J. 2004. Integrated wetland assessment program, part 4: vegetation index of biotic integrity (VIBI) and tiered aquatic life uses (TALUs) for Ohio wetlands. Ohio EPA Technical Report WET/2004-4, Ohio Environmental Protection Agency, Wetland Ecology Group, Division of Surface Water, Columbus, Ohio.

Mantel, N. 1967. The detection of disease clustering and a generalized regression approach. Cancer Research 27:209-220.

Martin, D. W. and J. C. Chambers. 2001. Effects of water table, clipping, and species interactions on Carex nebrascensis and Poa pratensis in riparian meadows. Wetlands 21:422-430.

Mather, P. M. 1976. Computational methods of multivariate analysis in physical geography. J. Wiley \& Sons, London.

McCormick, F. H., R. M. Hughes, P. R. Kaufmann, D. V. Peck, J. L. Stoddard, and A. T. Herlihy. 2001. Development of an index of biotic integrity for the mid-Atlantic highlands region. Transactions of the American Fisheries Society 130:857-877.

McCune, B. and M. J. Mefford. 1999. PC-ORD. Multivariate analysis of ecological data, version 4.36. MjM Software Design, Gleneden Beach, Oregon.

McCune, B. and J. B. Grace. 2002. Analysis of ecological communities. MjM Software Design, Gleneden Beach, Oregon.

McIntyre, S., S. Lavorel, and R. M. Tremont. 1995. Plant life-history attributes: their relationship to disturbance response in herbaceous vegetation. Journal of Ecology 83:31-44.

Mebane, C. A., T. R. Maret, and R. M. Hughes. 2003. A performance comparison of metric scoring methods for a multimetric index for mid-Atlantic highlands streams. Transactions of the American Fisheries Society 132:239-261.

Minns, C. K., V. W. Cairns, R. G. Randall, and J. E. Moore. 1994. An index of biotic integrity (IBI) for fish assemblages in the littoral zone of Great Lake areas of concern. Canadian Journal Fisheries and Aquatic Sciences 51:1804-1822. 
Mueller-Dombois, D. and H. Ellenberg. 1974. Aims and methods of vegetation ecology. John Wiley $\&$ Sons, New York, New York.

Mushet, D. M., N. H. Euliss, Jr., and T. L. Shaffer. 2002. Floristic quality assessment of one natural and three restored wetland complexes in North Dakota, USA. Wetlands 22:126-38.

Natural Resources Conservation Service. 2004. The PLANTS database, version 3.5. U.S. Department of Agriculture, Natural Resources Conservation Service, National Plant Data Center. Available at http://plants.usda.gov.

Northern Great Plains Floristic Quality Assessment Panel. 2001. Floristic quality assessment for plant communities of North Dakota, South Dakota (excluding the Black Hills), and adjacent grasslands. Northern Prairie Wildlife Resource Center, Jamestown, North Dakota. Available at http://www.npwrc.usgs.gov/ resource/2001/fqa/fqa.htm. Accessed on 10/5/ 2002.

Oden, N. L. and R. R. Sokal. 1986. Directional autocorrelation: an extension of spatial correlograms to two dimensions. Systematic Zoology 35:608-617.

Oksanen, J., R. Kindt, and R. B. O’Hara. 2005. vegan: Community ecology package for $\mathrm{R}$, version 1.6-9. Available at http://cc.oulu.fi/ jarioksa/.

Patten, D. T. 1998. Riparian ecosystems of semiarid North America: diversity and human impacts. Wetlands 18:498-512.

Pausas, J. G. and S. Lavorel. 2003. A hierarchical deductive approach for functional types in disturbed ecosystems. Journal of Vegetation Science 14:409-416.

Prichard, D., J. Anderson, C. Correll, J. Fogg, K. Gebhardt, R. Krapf, S. Leonard, B. Mitchell, and J. Staats. 1998. Riparian area management: a user guide to assessing proper functioning condition and the supporting science for lotic areas. Technical Reference 1737-15, U.S. Department of the Interior, Bureau of Land Management, Denver, Colorado.

R Development Core Team. 2005. R: a language and environment for statistical computing, version 2.1.0. $R$ Foundation for Statistical Computing, Vienna, Austria. Available at http:// www.r-project.org/.
Rahel, F. J. 1990. The hierarchical nature of community persistence: a problem of scale. American Naturalist 136:328-344.

Raunkiaer, C. 1934. The life forms of plants and statistical plant geography. Clarendon Press, Oxford.

Reed, P. B. 1993. National list of plant species that occur in wetlands: 1988 national summary and 1993 Northwest region 9 supplement. U.S. Fish and Wildlife Service in cooperation with the U.S. Army Corps of Engineers, U.S.

Environmental Protection Agency, and U.S. Soil Conservation Service. Available at http:// wetlands.fws.gov/bha/list88.html.

Rosgen, D. L. 1996. Applied river morphology. Wildland Hydrology, Pagosa Springs, Colorado.

Ruppel, E. T. 1999. Geologic map of the eastern part of the Leadore 30' x 60' quadrangle, Montana and Idaho (revised). Open File Report MBMG 372, Montana Bureau of Mines and Geology, Butte, Montana.

Ruppel, E. T., J. M. O’Neill, and D. A. Lopez. 1993. Geologic map of the Dillon $1^{\circ} \times 2^{\circ}$ quadrangle, Montana and Idaho. Miscellaneous Investigations Series Map I-1803-H, U.S. Geological Survey, Denver, Colorado.

Sawada, M. 1999. Rookcase: an Excel 97/2000 visual basic (VB) add-in for exploring global and local spatial autocorrelation. Bulletin of the Ecological Society of America 80:231-234.

Schulz, T. T. and W. C. Leininger. 1990.

Differences in riparian vegetation structure between grazed areas and exclosures. Journal of Range Management 43:295-299.

Simon, A. and J. C. Collison. 2002. Quantifying the mechanical and hydrologic effects of riparian vegetation on streambank stability. Earth Surface Processes and Landforms 27:527-546.

Skipp, B. and S. U. Janecke. 2004. Geologic map of the Montana part of the Dubois 30' x 60' quadrangle, southwest Montana. Open File Report MBMG 490, Montana Bureau of Mines and Geology, Butte, Montana.

Sokal, R. R. and F. J. Rohlf. 1995. Biometry, 3rd edition. W. H. Freeman and Company, New York, New York. 
Swink, F. A. and G. S. Wilhelm. 1979. Plants of the Chicago region: a checklist of the vascular flora of the Chicago region, with keys, notes on local distribution, ecology, and taxonomy, and a system for evaluation of plant communities. Morton Arboretum, Lisle, Illinois.

Teels, B. M. and P. Adamus. 2002. Methods for evaluating wetland condition: developing metrics and indices of biological integrity. EPA822-R-02-016, Office of Water, U.S. Environmental Protection Agency, Washington, D.C.

Therneau, T. M. and B. Atkinson. 2005. rpart: Recursive partitioning package for $\mathrm{R}$, version 3.1-23. Available at http://cran.r-project.org/.

Thorne, M. S., P. J. Meiman, Q. D. Skinner, M. A. Smith, and J. L. Dodd. 2005. Clipping frequency affects canopy volume and biomass production in planeleaf willow (Salix planifolia var. planifolia Prush). Rangeland Ecology and Management 58:41-50.

Urban, D. L. 2002. Classification and regression trees. Pages 222-232 in B. McCune and J. B. Grace, editors. Analysis of ecological communities. MjM Software Design, Gleneden Beach, Oregon.

US Census Bureau. 2003. Montana roads from TIGER/line files. U.S. Census Bureau Geography Division, Helena, Montana. Available at http://nris.state.mt.us/nsdi/nris/ road2000/road2000.html.

US Geological Survey. 2002. National elevation dataset for Montana. U.S. Geological Survey, Helena, Montana. Available at http:// nris.state.mt.us/nsdi/nris/el10/dems.html.

USEPA. 1998. Lake and reservoir bioassessment and biocriteria. Technical Guidance Document EPA 841-B-98-007, U.S. Environmental Protection Agency, Office of Wetlands, Oceans, and Watersheds, Washington, D.C.
Venables, W. N. and B. D. Ripley. 2002. Modern applied statistics with $S$, 4th edition. SpringerVerlag, New York, New York.

Western Regional Climate Center. 2005. Montana climate summaries, National Climatic Data Center 1971-2000 climate normals. National Oceanic and Atmospheric Administration. Available at http://www.wrcc.dri.edu/summary/ climsmmt.html. Accessed on 2/21/2005.

Wheeler, M. A., M. J. Trlica, G. W. Frasier, and J. D. Reeder. 2002. Seasonal grazing affects soil physical properties of a montane riparian community. Journal of Range Management 55:49-56.

Whittaker, R. J. 1972. Evolution and measurement of species diversity. Taxon 21:213-51.

Wilcox, D. A., J. E. Meeker, P. L. Hudson, B. J. Armitage, M. G. Black, and D. G. Uzarski. 2002. Hydrologic variability and the application of index of biotic integrity metrics to wetlands: a Great Lakes evaluation. Wetlands 22:588615.

Wilhelm, G. and D. Ladd. 1988. Natural area assessment in the Chicago region. Pages 361375 in Transactions of the 53rd North American Wildlife and Natural Resources Conference (Louisville, Kentucky). Wildlife Management Institute, Washington, D.C.

Winward, A. H. 2000. Monitoring the vegetation resources in riparian areas. General Technical Report RMRS-GTR-47, U.S. Department of Agriculture, Forest Service, Rocky Mountain Research Station, Ogden, Utah.

Woods, A. J., J. M. Omernik, J. A. Nesser, J. Shelden, and S. H. Azevedo. 1999. Ecoregions of Montana. (1:1,500,000 map), U.S. Geological Survey, Reston, Virginia. 



\section{ApPendix A. CoefFicients of CONSERVATION FOR SELECTED WET- LAND PLANTS THAT OCCUR IN WESTERN MONTANA.}



Appendix A. Coefficients of conservation for selected wetland plants that occur in western Montana.

Coefficients of conservatism were assigned to 747 plant species known to occur in wetlands in western Montana. Species were selected based on the species list in Lesica and Husby (2001, Appendix A). Coefficients for a few additional non-wetland species were assigned because they were sampled in the course of the study. Coefficients were determined by a panel of expert botanists. Panel members were Stephen Cooper (Vegetation Ecologist, Montana Natural Heritage Program), Marc Jones (Ecologist, Montana Natural Heritage Program), Peter Lesica (Botanical Consultant), Mary Manning (Vegetation Ecologist, U.S. Forest Service), Scott Mincemoyer (Botanist, Montana Natural Heritage Program), John Pierce (Botanical Consultant), and Steve Shelly (Regional Botanist, U.S. Forest Service). Coefficients for 345 species were assigned by the entire committee; coefficients for the remaining 402 species were assigned by Marc Jones, Peter Lesica, and John Pierce. Nomenclature follows the federal naming standard (Natural Resources Conservation Service 2004). For unfamiliar names, a partial synonymy can be found by consulting the PLANTS database at http://plants.usda.gov.

\section{Literature Cited}

Lesica, P. and P. Husby. 2001. Field guide to Montana's wetland vascular plants. Montana Wetlands Trust, Helena, Montana.

Natural Resources Conservation Service. 2004. The PLANTS database, version 3.5. U.S. Department of Agriculture, Natural Resources Conservation Service, National Plant Data Center. Available at http://plants.usda.gov. 
Coefficients of conservatism $(C)$ for 747 wetland plants species known to occur in western Montana.

\begin{tabular}{|c|c|c|}
\hline$C$ & Scientific Name & Common Name \\
\hline 4 & Acer glabrum Torr. & Rocky Mountain maple \\
\hline 2 & Acer negundo L. & boxelder \\
\hline 6 & Achnatherum nelsonii (Scribn.) Barkworth & Columbia needlegrass \\
\hline 5 & Aconitum columbianum Nutt. & Columbian monkshood \\
\hline 7 & Actaea rubra (Ait.) Willd. & red baneberry \\
\hline 7 & Adiantum aleuticum (Rupr.) Paris & Aleutian maidenhair \\
\hline 5 & Agoseris aurantiaca (Hook.) Greene & orange agoseris \\
\hline 4 & Agoseris glauca (Pursh) Raf. & pale agoseris \\
\hline 3 & Agrostis exarata Trin. & spike bentgrass \\
\hline 1 & Agrostis gigantea Roth & redtop \\
\hline 8 & Agrostis humilis Vasey & alpine bentgrass \\
\hline 2 & Agrostis scabra Willd. & rough bentgrass \\
\hline 6 & Allium brevistylum S. Wats. & shortstyle onion \\
\hline 6 & Allium schoenoprasum L. & wild chives \\
\hline 6 & Alnus incana (L.) Moench & gray alder \\
\hline 6 & Alnus viridis (Vill.) Lam. \& DC. & green alder \\
\hline 4 & Alopecurus aequalis Sobol. & shortawn foxtail \\
\hline 6 & Alopecurus alpinus Sm. & boreal alopecurus \\
\hline 4 & Alopecurus carolinianus Walt. & Carolina foxtail \\
\hline 2 & Alopecurus geniculatus L. & water foxtail \\
\hline 0 & Alopecurus pratensis L. & meadow foxtail \\
\hline 0 & Amaranthus blitoides S. Wats. & mat amaranth \\
\hline 7 & Amaranthus californicus (Moq.) S. Wats. & California amaranth \\
\hline 3 & Ambrosia psilostachya DC. & Cuman ragweed \\
\hline 1 & Ambrosia trifida L. & great ragweed \\
\hline 10 & Amerorchis rotundifolia (Banks ex Pursh) Hultén & roundleaf orchid \\
\hline 2 & Androsace filiformis Retz. & filiform rockjasmine \\
\hline 6 & Anemone parviflora Michx. & smallflowered anemone \\
\hline 5 & Angelica arguta Nutt. & Lyall's angelica \\
\hline 7 & Angelica dawsonii S. Wats. & Dawson's angelica \\
\hline 4 & Angelica pinnata S. Wats. & small-leaf angelica \\
\hline 3 & Antennaria corymbosa E. Nels. & flat-top pussytoes \\
\hline 3 & Antennaria microphylla Rydb. & littleleaf pussytoes \\
\hline 4 & Apocynum cannabinum L. & Indianhemp \\
\hline 6 & Aquilegia caerulea James & Colorado blue columbine \\
\hline 6 & Aquilegia formosa Fisch. ex DC. & western columbine \\
\hline 0 & Arenaria serpyllifolia L. & thymeleaf sandwort \\
\hline 3 & Argentina anserina (L.) Rydb. & silverweed cinquefoil \\
\hline 5 & Arnica amplexicaulis Nutt. & clasping arnica \\
\hline 5 & Arnica chamissonis Less. & Chamisso arnica \\
\hline 7 & Arnica longifolia D.C. Eat. & spearleaf arnica \\
\hline 6 & Arnica mollis Hook. & hairy arnica \\
\hline 2 & Artemisia biennis Willd. & biennial wormwood \\
\hline 4 & Artemisia cana Pursh & silver sagebrush \\
\hline 7 & Artemisia lindleyana Bess. & Columbia River wormwood \\
\hline 3 & Artemisia ludoviciana Nutt. & white sagebrush \\
\hline 5 & Artemisia tridentata Nutt. ssp. tridentata & basin big sagebrush \\
\hline 3 & Artemisia tridentata Nutt. ssp. vaseyana (Rydb.) Beetle & mountain big sagebrush \\
\hline
\end{tabular}




\begin{tabular}{|c|c|c|}
\hline C & Scientific Name & Common Name \\
\hline 4 & $\begin{array}{l}\text { Artemisia tridentata Nutt. ssp. wyomingensis Beetle \& } \\
\text { Young }\end{array}$ & Wyoming big sagebrush \\
\hline 0 & Asclepias speciosa Torr. & showy milkweed \\
\hline 3 & Astragalus agrestis Dougl. ex G. Don & purple milkvetch \\
\hline 6 & Astragalus americanus (Hook.) M.E. Jones & American milkvetch \\
\hline 3 & Astragalus canadensis L. & Canadian milkvetch \\
\hline 5 & Athyrium filix-femina (L.) Roth & common ladyfern \\
\hline 0 & Atriplex patula L. & spear saltbush \\
\hline 5 & Atriplex truncata (Torr. ex S. Wats.) Gray & wedgescale saltbush \\
\hline 7 & Bacopa rotundifolia (Michx.) Wettst. & disk waterhyssop \\
\hline 4 & Barbarea orthoceras Ledeb. & American yellowrocket \\
\hline 0 & Barbarea vulgaris Ait. f. & garden yellowrocket \\
\hline 4 & Beckmannia syzigachne (Steud.) Fern. & American sloughgrass \\
\hline 7 & Berula erecta (Huds.) Coville & cutleaf waterparsnip \\
\hline 8 & Betula nana L. & dwarf birch \\
\hline 5 & Betula occidentalis Hook. & water birch \\
\hline 4 & Bidens cernua L. & nodding beggartick \\
\hline 6 & Bidens tripartita L. & threelobe beggarticks \\
\hline 6 & Bidens vulgata Greene & big devils beggartick \\
\hline 6 & Botrychium lanceolatum (Gmel.) Angstr. & lanceleaf grapefern \\
\hline 4 & Botrychium lunaria (L.) Sw. & common moonwort \\
\hline 8 & Botrychium multifidum (Gmel.) Trev. & leathery grapefern \\
\hline 7 & Botrychium pinnatum St. John & northern moonwort \\
\hline 6 & Botrychium simplex E. Hitchc. & little grapefern \\
\hline 7 & Boykinia major Gray & large boykinia \\
\hline 6 & Bromus ciliatus L. & fringed brome \\
\hline 0 & Bromus inermis Leyss. & smooth brome \\
\hline 5 & Bromus marginatus Nees ex Steud. & mountain brome \\
\hline 5 & Calamagrostis canadensis (Michx.) Beauv. & bluejoint \\
\hline 6 & Calamagrostis stricta (Timm) Koel. & slimstem reedgrass \\
\hline 6 & Callitriche hermaphroditica L. & northern water-starwort \\
\hline 3 & Callitriche heterophylla Pursh & twoheaded water-starwort \\
\hline 7 & Caltha leptosepala DC. & white marsh marigold \\
\hline 6 & Calypso bulbosa (L.) Oakes & fairy slipper \\
\hline 6 & Camassia quamash (Pursh) Greene & small camas \\
\hline 5 & Camissonia subacaulis (Pursh) Raven & diffuseflower evening-primrose \\
\hline 7 & Campanula parryi Gray & Parry's bellflower \\
\hline 3 & Campanula rotundifolia $\mathrm{L}$. & bluebell bellflower \\
\hline 9 & Campanula uniflora $\mathrm{L}$. & arctic bellflower \\
\hline 6 & Canadanthus modestus (Lindl.) Nesom & giant mountain aster \\
\hline 7 & Cardamine breweri S. Wats. & Brewer's bittercress \\
\hline 3 & Cardamine oligosperma Nutt. & little western bittercress \\
\hline 3 & Cardamine pensylvanica Muhl. ex Willd. & Pennsylvania bittercress \\
\hline 5 & Carex amplifolia Boott & bigleaf sedge \\
\hline 6 & Carex aperta Boott & Columbian sedge \\
\hline 5 & Carex aquatilis Wahlenb. & water sedge \\
\hline 6 & Carex arcta Boott & northern cluster sedge \\
\hline 5 & Carex atherodes Spreng. & wheat sedge \\
\hline 4 & Carex athrostachya Olney & slenderbeak sedge \\
\hline
\end{tabular}




\begin{tabular}{|c|c|c|}
\hline$C$ & Scientific Name & Common Name \\
\hline 7 & Carex atratiformis Britt. & scabrous black sedge \\
\hline 6 & Carex aurea Nutt. & golden sedge \\
\hline 7 & Carex bebbii Olney ex Fern. & Bebb's sedge \\
\hline 4 & Carex brevior (Dewey) Mackenzie & shortbeak sedge \\
\hline 8 & Carex brunnescens (Pers.) Poir. & brownish sedge \\
\hline 8 & Carex buxbaumii Wahlenb. & Buxbaum's sedge \\
\hline 8 & Carex canescens L. & silvery sedge \\
\hline 8 & Carex capillaris L. & hairlike sedge \\
\hline 7 & Carex capitata $\mathrm{L}$. & capitate sedge \\
\hline 9 & Carex chordorrhiza Ehrh. ex L. f. & creeping sedge \\
\hline 7 & Carex comosa Boott & longhair sedge \\
\hline 6 & Carex crawei Dewey & Crawe's sedge \\
\hline 7 & Carex cusickii Mackenzie ex Piper \& Beattie & Cusick's sedge \\
\hline 6 & Carex deweyana Schwein. & Dewey sedge \\
\hline 8 & Carex diandra Schrank & lesser panicled sedge \\
\hline 6 & Carex disperma Dewey & softleaf sedge \\
\hline 8 & Carex echinata Murr. & star sedge \\
\hline 7 & Carex flava L. & yellow sedge \\
\hline 7 & Carex foenea Willd. & dryspike sedge \\
\hline 9 & Carex gynocrates Wormsk. ex Drej. & northern bog sedge \\
\hline 7 & Carex heteroneura W. Boott & different nerve sedge \\
\hline 5 & Carex hystericina Muhl. ex Willd. & bottlebrush sedge \\
\hline 7 & Carex idahoa Bailey & Idaho sedge \\
\hline 7 & Carex illota Bailey & sheep sedge \\
\hline 8 & Carex interior Bailey & inland sedge \\
\hline 9 & Carex lachenalii Schkuhr & twotipped sedge \\
\hline 9 & Carex lacustris Willd. & hairy sedge \\
\hline 5 & Carex laeviconica Dewey & smoothcone sedge \\
\hline 6 & Carex laeviculmis Meinsh. & smoothstem sedge \\
\hline 7 & Carex lasiocarpa Ehrh. & woollyfruit sedge \\
\hline 5 & Carex lenticularis Michx. & lakeshore sedge \\
\hline 8 & Carex leptalea Wahlenb. & bristlystalked sedge \\
\hline 9 & Carex limosa L. & mud sedge \\
\hline 9 & Carex livida (Wahlenb.) Willd. & livid sedge \\
\hline 7 & Carex luzulina Olney & woodrush sedge \\
\hline 3 & Carex mertensii Prescott ex Bong. & Mertens' sedge \\
\hline 3 & Carex microptera Mackenzie & smallwing sedge \\
\hline 3 & Carex nebrascensis Dewey & Nebraska sedge \\
\hline 7 & Carex nelsonii Mackenzie & Nelson's sedge \\
\hline 7 & Carex neurophora Mackenzie & alpine nerve sedge \\
\hline 7 & Carex nigricans C.A. Mey. & black alpine sedge \\
\hline 8 & Carex norvegica Retz. & Norway sedge \\
\hline 7 & Carex nova Bailey & black sedge \\
\hline 7 & Carex pachystachya Cham. ex Steud. & chamisso sedge \\
\hline 5 & Carex parryana Dewey & Parry's sedge \\
\hline 4 & Carex pellita Muhl ex Willd. & woolly sedge \\
\hline 7 & Carex podocarpa R. Br. & shortstalk sedge \\
\hline 7 & Carex praeceptorium Mackenzie & early sedge \\
\hline 4 & Carex praegracilis W. Boott & clustered field sedge \\
\hline
\end{tabular}




\begin{tabular}{|c|c|c|}
\hline$C$ & Scientific Name & Common Name \\
\hline 4 & Carex praticola Rydb. & meadow sedge \\
\hline 7 & Carex pyrenaica Wahlenb. & Pyrenean sedge \\
\hline 7 & Carex sartwellii Dewey & Sartwell's sedge \\
\hline 8 & Carex saxatilis L. & rock sedge \\
\hline 7 & Carex scoparia Schkuhr ex Willd. & broom sedge \\
\hline 8 & Carex scopulorum Holm & mountain sedge \\
\hline 8 & Carex simulata Mackenzie & analogue sedge \\
\hline 7 & Carex spectabilis Dewey & showy sedge \\
\hline 8 & Carex sprengelii Dewey ex Spreng. & Sprengel's sedge \\
\hline 4 & Carex stipata Muhl. ex Willd. & owlfruit sedge \\
\hline 8 & Carex sychnocephala Carey & manyhead sedge \\
\hline 10 & Carex tenuiflora Wahlenb. & sparseflower sedge \\
\hline 9 & Carex torreyi Tuckerman & Torrey's sedge \\
\hline 3 & Carex utriculata Boott & Northwest Territory sedge \\
\hline 5 & Carex vesicaria L. & blister sedge \\
\hline 8 & Carex viridula Michx. & little green sedge \\
\hline 6 & Carex vulpinoidea Michx. & fox sedge \\
\hline 4 & Castilleja miniata Dougl. ex Hook. & giant red Indian paintbrush \\
\hline 3 & Castilleja minor (Gray) Gray & lesser Indian paintbrush \\
\hline 7 & Castilleja occidentalis Torr. & western Indian paintbrush \\
\hline 7 & Castilleja rhexiifolia Rydb. & splitleaf Indian paintbrush \\
\hline 7 & Castilleja sulphurea Rydb. & sulphur Indian paintbrush \\
\hline 3 & Catabrosa aquatica (L.) Beauv. & water whorlgrass \\
\hline 3 & Ceratophyllum demersum L. & coon's tail \\
\hline 1 & Chamerion angustifolium (L.) Holub & fireweed \\
\hline 0 & Chenopodium album L. & lambsquarters \\
\hline 3 & Chenopodium rubrum L. & red goosefoot \\
\hline 4 & Chrysosplenium tetrandrum (Lund ex Malmgr.) Th. Fries & northern golden saxifrage \\
\hline 7 & Cicuta bulbifera $\mathrm{L}$. & bulblet-bearing water hemlock \\
\hline 4 & Cicuta douglasii (DC.) Coult. \& Rose & western water hemlock \\
\hline 3 & Cicuta maculata $\mathrm{L}$. & spotted water hemlock \\
\hline 5 & Circaea alpina $\mathrm{L}$. & small enchanter's nightshade \\
\hline 0 & Cirsium arvense (L.) Scop. & Canada thistle \\
\hline 5 & Cirsium scariosum Nutt. & meadow thistle \\
\hline 4 & Cirsium undulatum (Nutt.) Spreng. & wavyleaf thistle \\
\hline 0 & Cirsium vulgare (Savi) Ten. & bull thistle \\
\hline 2 & Claytonia perfoliata Donn ex Willd. & miner's lettuce \\
\hline 5 & Claytonia sibirica $\mathrm{L}$. & Siberian springbeauty \\
\hline 6 & Coeloglossum viride (L.) Hartman & longbract frog orchid \\
\hline 3 & Collomia linearis Nutt. & tiny trumpet \\
\hline 7 & Comarum palustre L. & purple marshlocks \\
\hline 0 & Conium maculatum $\mathrm{L}$. & poison hemlock \\
\hline 8 & Corallorrhiza trifida Chatelain & yellow coralroot \\
\hline 9 & Corallorrhiza wisteriana Conrad & spring coralroot \\
\hline 6 & Coreopsis tinctoria Nutt. & golden tickseed \\
\hline 7 & Cornus canadensis L. & bunchberry dogwood \\
\hline 5 & Cornus sericea L. & redosier dogwood \\
\hline 5 & Crataegus douglasii Lindl. & black hawthorn \\
\hline 5 & Crepis runcinata (James) Torr. \& Gray & fiddleleaf hawksbeard \\
\hline
\end{tabular}




\begin{tabular}{|c|c|c|}
\hline$C$ & Scientific Name & Common Name \\
\hline 0 & Cynoglossum officinale L. & gypsyflower \\
\hline 8 & Cyperus schweinitzii Torr. & Schweinitz's flatsedge \\
\hline 7 & Cypripedium fasciculatum Kellogg ex S. Wats. & clustered lady's slipper \\
\hline 9 & Cypripedium parviflorum Salisb. & lesser yellow lady's slipper \\
\hline 10 & Cypripedium passerinum Richards. & sparrowegg lady's slipper \\
\hline 10 & Cystopteris montana (Lam.) Bernh. ex Desv. & mountain bladderfern \\
\hline 5 & Danthonia intermedia Vasey & timber oatgrass \\
\hline 3 & Dasiphora floribunda (Pursh) Kartesz, comb. nov. ined. & shrubby cinquefoil \\
\hline 7 & Delphinium depauperatum Nutt. & slim larkspur \\
\hline 6 & Delphinium glaucum S. Wats. & Sierra larkspur \\
\hline 7 & Deschampsia caespitosa (L.) Beauv. & tufted hairgrass \\
\hline 5 & Deschampsia danthonioides (Trin.) Munro & annual hairgrass \\
\hline 4 & Deschampsia elongata (Hook.) Munro & slender hairgrass \\
\hline 9 & $\begin{array}{l}\text { Dichanthelium acuminatum (Sw.) Gould \& C.A. Clark var. } \\
\text { fasciculatum (Torr.) Freckmann }\end{array}$ & western panicgrass \\
\hline 5 & Distichlis spicata (L.) Greene & inland saltgrass \\
\hline 7 & Dodecatheon jeffreyi Van Houtte & Sierrra shootingstar \\
\hline 5 & Dodecatheon pulchellum (Raf.) Merr. & darkthroat shootingstar \\
\hline 7 & Draba aurea Vahl ex Hornem. & golden draba \\
\hline 9 & Dryopteris cristata (L.) Gray & crested woodfern \\
\hline 0 & Echinochloa muricata (Beauv.) Fern. & rough barnyardgrass \\
\hline 5 & Echinocystis lobata (Michx.) Torr. \& Gray & wild cucumber \\
\hline 0 & Elaeagnus angustifolia $\mathrm{L}$. & Russian olive \\
\hline 6 & Elatine californica Gray & California waterwort \\
\hline 6 & Elatine rubella Rydb. & southwestern waterwort \\
\hline 4 & Eleocharis acicularis (L.) Roemer \& J.A. Schultes & needle spikerush \\
\hline 4 & Eleocharis palustris (L.) Roemer \& J.A. Schultes & common spikerush \\
\hline 7 & Eleocharis quinqueflora (F.X. Hartmann) Schwarz & fewflower spikerush \\
\hline 9 & Eleocharis rostellata (Torr.) Torr. & beaked spikerush \\
\hline 8 & Elodea bifoliata St. John & twoleaf waterweed \\
\hline 7 & Elodea canadensis Michx. & Canadian waterweed \\
\hline 4 & Elodea nuttallii (Planch.) St. John & western waterweed \\
\hline 5 & Elymus canadensis L. & Canada wildrye \\
\hline 5 & Elymus glaucus Buckl. & blue wildrye \\
\hline 0 & Elymus repens (L.) Gould & quackgrass \\
\hline 6 & Elymus submuticus (Hook.) Smyth \& Smyth & Virginia wildrye \\
\hline 5 & Elymus trachycaulus (Link) Gould ex Shinners & slender wheatgrass \\
\hline 5 & Epilobium anagallidifolium Lam. & pimpernel willowherb \\
\hline 3 & Epilobium ciliatum Raf. & fringed willowherb \\
\hline 5 & Epilobium glaberrimum Barbey & glaucus willowherb \\
\hline 7 & Epilobium palustre L. & marsh willowherb \\
\hline 2 & Equisetum arvense L. & field horsetail \\
\hline 6 & Equisetum fluviatile L. & water horsetail \\
\hline 3 & Equisetum hyemale L. & scouringrush horsetail \\
\hline 4 & Equisetum laevigatum A. Braun & smooth horsetail \\
\hline 6 & Equisetum palustre $\mathrm{L}$. & marsh horsetail \\
\hline 6 & Equisetum pratense Ehrh. & meadow horsetail \\
\hline 7 & Equisetum scirpoides Michx. & dwarf scouringrush \\
\hline
\end{tabular}




\begin{tabular}{|c|c|c|}
\hline$C$ & Scientific Name & Common Name \\
\hline 5 & $\begin{array}{l}\text { Equisetum variegatum Schleich. ex F. Weber \& D.M.H. } \\
\text { Mohr }\end{array}$ & variegated scouringrush \\
\hline 4 & Eragrostis hypnoides (Lam.) B.S.P. & teal lovegrass \\
\hline 4 & Eragrostis pectinacea (Michx.) Nees ex Steud. & tufted lovegrass \\
\hline 2 & Ericameria nauseosa (Pallas ex Pursh) Nesom \& Baird & rubber rabbitbrush \\
\hline 5 & Erigeron acris L. & bitter fleabane \\
\hline 6 & Erigeron coulteri Porter & large mountain fleabane \\
\hline 3 & Erigeron flagellaris Gray & trailing fleabane \\
\hline 6 & Erigeron gracilis Rydb. & quill fleabane \\
\hline 8 & Erigeron humilis Graham & arctic alpine fleabane \\
\hline 4 & Erigeron lonchophyllus Hook. & shortray fleabane \\
\hline 7 & Erigeron peregrinus (Banks ex Pursh) Greene & subalpine fleabane \\
\hline 3 & Erigeron philadelphicus L. & Philadelphia fleabane \\
\hline 10 & Eriophorum scheuchzeri Hoppe & white cottongrass \\
\hline 5 & Eupatorium maculatum L. & spotted joepyeweed \\
\hline 7 & Euthamia graminifolia (L.) Nutt. & flat-top goldentop \\
\hline 7 & Euthamia occidentalis Nutt. & western goldentop \\
\hline 4 & Festuca idahoensis Elmer & Idaho fescue \\
\hline 1 & Festuca rubra L. & red fescue \\
\hline 7 & Festuca subulata Trin. & bearded fescue \\
\hline 3 & Fragaria virginiana Duchesne & Virginia strawberry \\
\hline 4 & Galium boreale L. & northern bedstraw \\
\hline 2 & Galium mexicanum Kunth & Mexican bedstraw \\
\hline 5 & Galium palustre L. & common marsh bedstraw \\
\hline 6 & Galium trifidum L. & threepetal bedstraw \\
\hline 6 & Galium triflorum Michx. & fragrant bedstraw \\
\hline 8 & Gaultheria humifusa (Graham) Rydb. & alpine spicywintergreen \\
\hline 8 & Gaultheria ovatifolia Gray & western teaberry \\
\hline 6 & Gentiana affinis Griseb. & pleated gentian \\
\hline 9 & Gentiana algida Pallas & whitish gentian \\
\hline 7 & Gentiana calycosa Griseb. & Rainier pleated gentian \\
\hline 10 & Gentiana glauca Pallas & pale gentian \\
\hline 6 & Gentiana prostrata Haenke & pygmy gentian \\
\hline 3 & Gentianella amarella (L.) Boerner & autumn dwarf gentian \\
\hline 10 & Gentianella propinqua (Richards.) J. Gillett & fourpart dwarf gentian \\
\hline 6 & Gentianella tenella (Rottb.) Boerner & Dane's dwarf gentian \\
\hline 9 & Gentianopsis simplex (Gray) Iltis & oneflower fringed gentian \\
\hline 8 & Gentianopsis thermalis (Kuntze) Iltis & Rocky Mountain fringed gentian \\
\hline 5 & Geranium richardsonii Fisch. \& Trautv. & Richardson's geranium \\
\hline 4 & Geranium viscossisimum Fisch. \& Trautv. & Sticky geranium \\
\hline 6 & Geum aleppicum Jacq. & yellow avens \\
\hline 5 & Geum macrophyllum Willd. & largeleaf avens \\
\hline 7 & Geum rivale $\mathrm{L}$. & purple avens \\
\hline 5 & Glaux maritima L. & sea milkwort \\
\hline 6 & Glyceria borealis (Nash) Batchelder & small floating mannagrass \\
\hline 7 & Glyceria grandis S. Wats. & American mannagrass \\
\hline 6 & Glyceria striata (Lam.) A.S. Hitchc. & fowl mannagrass \\
\hline 3 & Glycyrrhiza lepidota Pursh & American licorice \\
\hline 3 & Gnaphalium palustre Nutt. & western marsh cudweed \\
\hline
\end{tabular}




\begin{tabular}{|c|c|c|}
\hline C & Scientific Name & Common Name \\
\hline 8 & Gratiola ebracteata Benth. ex A. DC. & bractless hedgehyssop \\
\hline 8 & Gratiola neglecta Torr. & clammy hedgehyssop \\
\hline 2 & Grindelia howellii Steyermark & Howell's gumweed \\
\hline 2 & Grindelia squarrosa (Pursh) Dunal & curlycup gumweed \\
\hline 7 & Gymnocarpium dryopteris (L.) Newman & western oakfern \\
\hline 6 & Helenium autumnale L. & common sneezeweed \\
\hline 7 & Helianthus nuttallii Torr. \& Gray & Nuttall's sunflower \\
\hline 5 & Heliotropium curassavicum L. & salt heliotrope \\
\hline 5 & Heracleum maximum Bartr. & common cowparsnip \\
\hline 9 & Hesperochiron pumilus (Dougl. ex Griseb.) Porter & dwarf hesperochiron \\
\hline 8 & Hierochloe hirta (Schrank) Borbás & northern sweetgrass \\
\hline 6 & Hippuris vulgaris $\mathrm{L}$. & common mare's-tail \\
\hline 5 & Hordeum brachyantherum Nevski & meadow barley \\
\hline 2 & Hordeum jubatum L. & foxtail barley \\
\hline 9 & Howellia aquatilis Gray & water howellia \\
\hline 8 & Hypericum majus (Gray) Britt. & large St. Johnswort \\
\hline 7 & Hypericum scouleri Hook. & Scouler's St. Johnswort \\
\hline 3 & Impatiens ecalcarata Blank. & spurless touch-me-not \\
\hline 2 & Iris missouriensis Nutt. & Rocky Mountain iris \\
\hline 0 & Iris pseudacorus L. & paleyellow iris \\
\hline 7 & Isoetes bolanderi Engelm. & Bolander's quillwort \\
\hline 8 & Isoetes howellii Engelm. & Howell's quillwort \\
\hline 3 & Iva axillaris Pursh & povertyweed \\
\hline 3 & Iva xanthifolia Nutt. & giant sumpweed \\
\hline 5 & Juncus acuminatus Michx. & tapertip rush \\
\hline 9 & Juncus albescens (Lange) Fern. & northern white rush \\
\hline 7 & Juncus alpinoarticulatus Chaix & northern green rush \\
\hline 7 & Juncus articulatus L. & jointleaf rush \\
\hline 3 & Juncus balticus Willd. & Baltic rush \\
\hline 9 & Juncus biglumis L. & twoflowered rush \\
\hline 1 & Juncus bufonius L. & toad rush \\
\hline 9 & Juncus castaneus Sm. & chestnut rush \\
\hline 2 & Juncus compressus Jacq. & roundfruit rush \\
\hline 2 & Juncus confusus Coville & Colorado rush \\
\hline 7 & Juncus drummondii E. Mey. & Drummond's rush \\
\hline 6 & Juncus effusus L. & common rush \\
\hline 4 & Juncus ensifolius Wikstr. & swordleaf rush \\
\hline 7 & Juncus filiformis L. & thread rush \\
\hline 6 & Juncus hallii Engelm. & Hall's rush \\
\hline 5 & Juncus longistylis Torr. & longstyle rush \\
\hline 7 & Juncus mertensianus Bong. & Mertens' rush \\
\hline 6 & Juncus nevadensis S. Wats. & Sierra rush \\
\hline 8 & Juncus nevadensis Watson & Sierra rush \\
\hline 5 & Juncus nodosus L. & knotted rush \\
\hline 7 & Juncus parryi Engelm. & Parry's rush \\
\hline 3 & Juncus tenuis Willd. & poverty rush \\
\hline 5 & Juncus torreyi Coville & Torrey's rush \\
\hline 6 & Juncus tracyi Rydb. & Tracy's rush \\
\hline 8 & Juncus triglumis L. & threehulled rush \\
\hline
\end{tabular}




\begin{tabular}{|c|c|c|}
\hline$C$ & Scientific Name & Common Name \\
\hline 7 & Kobresia myosuroides (Vill.) Fiori & Bellardi bog sedge \\
\hline 9 & Kobresia simpliciuscula (Wahlenb.) Mackenzie & simple bog sedge \\
\hline 0 & Kochia scoparia (L.) Schrad. & Mexican-fireweed \\
\hline 3 & Lactuca biennis (Moench) Fern. & tall blue lettuce \\
\hline 4 & Lactuca tatarica (L.) C.A. Mey. & blue lettuce \\
\hline 7 & Ledum glandulosum Nutt. & western Labrador tea \\
\hline 8 & Leersia oryzoides (L.) Sw. & rice cutgrass \\
\hline 2 & Lemna minor L. & common duckweed \\
\hline 5 & Lemna trisulca L. & star duckweed \\
\hline 8 & Leptarrhena pyrolifolia (D. Don) R. Br. ex Ser. & fireleaf leptarrhena \\
\hline 4 & $\begin{array}{l}\text { Leptochloa fusca (L.) Kunth ssp. fascicularis (Lam.) N. } \\
\text { Snow }\end{array}$ & bearded sprangletop \\
\hline 5 & Leymus cinereus (Scribn. \& Merr.) A. Löve & basin wildrye \\
\hline 6 & Ligusticum canbyi Coult. \& Rose & Canby's licorice-root \\
\hline 7 & Ligusticum tenuifolium S. Wats. & Idaho licorice-root \\
\hline 7 & Ligusticum verticillatum (Hook.) Coult. \& Rose ex Rose & northern licorice-root \\
\hline 9 & Lilium philadelphicum L. & wood lily \\
\hline 4 & Limosella aquatica L. & water mudwort \\
\hline 9 & Listera borealis Morong & northern twayblade \\
\hline 7 & Listera caurina Piper & northwestern twayblade \\
\hline 8 & Listera convallarioides (Sw.) Nutt. ex Ell. & broadlipped twayblade \\
\hline 7 & Listera cordata (L.) R. Br. ex Ait. f. & heartleaf twayblade \\
\hline 7 & Lloydia serotina (L.) Reichenb. & common alplily \\
\hline 5 & Lobelia kalmii L. & Ontario lobelia \\
\hline 0 & Lolium pratense (Huds.) S.J. Darbyshire & meadow ryegrass \\
\hline 6 & Lomatogonium rotatum (L.) Fries ex Fern. & marsh felwort \\
\hline 8 & Lonicera caerulea L. & sweetberry honeysuckle \\
\hline 5 & Lonicera involucrata Banks ex Spreng. & twinberry honeysuckle \\
\hline 0 & Lotus corniculatus L. & birdfoot deervetch \\
\hline 5 & Lupinus aridus Dougl. & desert lupine \\
\hline 6 & Lupinus polyphyllus Lindl. & bigleaf lupine \\
\hline 7 & Luzula parviflora (Ehrh.) Desv. & smallflowered woodrush \\
\hline 8 & Luzula piperi (Coville) M.E. Jones & Piper's woodrush \\
\hline 9 & Lycopodium alpinum L. & alpine clubmoss \\
\hline 6 & Lycopodium annotinum L. & stiff clubmoss \\
\hline 10 & Lycopodium clavatum L. & running clubmoss \\
\hline 7 & Lycopodium complanatum L. & groundcedar \\
\hline 8 & Lycopus americanus Muhl. ex W. Bart. & American water horehound \\
\hline 6 & Lycopus asper Greene & rough bugleweed \\
\hline 9 & Lycopus uniflorus Michx. & northern bugleweed \\
\hline 8 & Lysichiton americanus Hultén \& St. John & American skunkcabbage \\
\hline 7 & Lysimachia ciliata L. & fringed loosestrife \\
\hline 8 & Lysimachia thyrsiflora $\mathrm{L}$. & tufted loosestrife \\
\hline 0 & Lythrum salicaria $\mathrm{L}$. & purple loosestrife \\
\hline 4 & Maianthemum racemosum (L.) Link & feathery false lily of the vally \\
\hline 4 & Maianthemum stellatum (L.) Link & starry false lily of the vally \\
\hline 4 & Marsilea vestita Hook. \& Grev. & hairy waterclover \\
\hline 6 & Melampyrum lineare Desr. & narrowleaf cowwheat \\
\hline 7 & Melica spectabilis Scribn. & purple oniongrass \\
\hline
\end{tabular}




\begin{tabular}{|c|c|c|}
\hline$C$ & Scientific Name & Common Name \\
\hline 3 & Mentha arvensis L. & wild mint \\
\hline 0 & Mentha spicata $\mathrm{L}$. & spearmint \\
\hline 6 & Mertensia ciliata (James ex Torr.) G. Don & tall fringed bluebells \\
\hline 7 & Mertensia paniculata (Ait.) G. Don & tall bluebells \\
\hline 3 & Mimulus breviflorus Piper & shortflower monkeyflower \\
\hline 3 & Mimulus floribundus Lindl. & manyflowered monkeyflower \\
\hline 5 & Mimulus guttatus DC. & seep monkeyflower \\
\hline 7 & Mimulus lewisii Pursh & purple monkeyflower \\
\hline 3 & Mimulus moschatus Dougl. ex Lindl. & muskflower \\
\hline 10 & Mimulus primuloides Benth. & primrose monkeyflower \\
\hline 7 & Mimulus tilingii Regel & Tiling's monkeyflower \\
\hline 5 & Minuartia rubella (Wahlenb.) Hiern. & beautiful sandwort \\
\hline 7 & Mitella breweri Gray & Brewer's miterwort \\
\hline 8 & Mitella nuda L. & naked miterwort \\
\hline 7 & Mitella pentandra Hook. & fivestamen miterwort \\
\hline 6 & Mitella stauropetala Piper & smallflower miterwort \\
\hline 5 & Moehringia lateriflora (L.) Fenzl & bluntleaf sandwort \\
\hline 0 & Mollugo verticillata $\mathrm{L}$. & green carpetweed \\
\hline 8 & Moneses uniflora (L.) Gray & single delight \\
\hline 0 & Monolepis nuttalliana (J.A. Schultes) Greene & Nuttall's povertyweed \\
\hline 4 & Montia chamissoi (Ledeb. ex Spreng.) Greene & water minerslettuce \\
\hline 2 & Montia dichotoma (Nutt.) T.J. Howell & dwarf minerslettuce \\
\hline 2 & Montia parvifolia (Moc. ex DC.) Greene & littleleaf minerslettuce \\
\hline 7 & Muhlenbergia asperifolia (Nees \& Meyen ex Trin.) Parodi & scratchgrass \\
\hline 4 & Muhlenbergia filiformis (Thurb. ex S. Wats.) Rydb. & pullup muhly \\
\hline 8 & Muhlenbergia glomerata (Willd.) Trin. & spiked muhly \\
\hline 2 & Muhlenbergia minutissima (Steud.) Swallen & annual muhly \\
\hline 4 & Muhlenbergia richardsonis (Trin.) Rydb. & mat muhly \\
\hline 0 & Myosotis arvensis (L.) Hill & field forget-me-not \\
\hline 7 & Myosotis asiatica (Vesterg.) Schischkin \& Sergievskaja & Asian forget-me-not \\
\hline 4 & Myosotis laxa Lehm. & bay forget-me-not \\
\hline 0 & Myosotis scorpioides L. & true forget-me-not \\
\hline 4 & Myosurus apetalus C. Gay & bristly mousetail \\
\hline 4 & Myosurus minimus L. & tiny mousetail \\
\hline 4 & Myriophyllum verticillatum L. & whorl-leaf watermilfoil \\
\hline 7 & Najas flexilis (Willd.) Rostk. \& Schmidt & nodding waternymph \\
\hline 6 & Navarretia intertexta (Benth.) Hook. & needleleaf navarretia \\
\hline 0 & Nepeta cataria L. & catnip \\
\hline 5 & Nuphar lutea (L.) Sm. & yellow pond-lily \\
\hline 0 & Nymphaea odorata Ait. & American white waterlily \\
\hline 9 & Nymphaea tetragona Georgi & pygmy waterlily \\
\hline 2 & Oenothera flava (A. Nels.) Garrett & yellow evening-primrose \\
\hline 1 & Oenothera villosa Thunb. & hairy evening-primrose \\
\hline 4 & Ophioglossum pusillum Raf. & northern adderstongue \\
\hline 7 & Oplopanax horridus Miq. & devilsclub \\
\hline 4 & Osmorhiza berteroi DC. & sweetcicely \\
\hline 6 & Osmorhiza occidentalis (Nutt. ex Torr. \& Gray) Torr. & western sweetroot \\
\hline 6 & Osmorhiza purpurea (Coult. \& Rose) Suksdorf & purple sweetroot \\
\hline 7 & Packera cymbalarioides (Buek) W.A. Weber \& A. Löve & cleftleaf groundsel \\
\hline
\end{tabular}




\begin{tabular}{|c|c|c|}
\hline$C$ & Scientific Name & Common Name \\
\hline 8 & Packera debilis (Nutt.) W.A. Weber \& A. Löve & weak groundsel \\
\hline 6 & Packera indecora (Greene) A.\& D. Löve & elegant groundsel \\
\hline 5 & Packera paupercula (Michx.) A.\& D. Löve & balsam groundsel \\
\hline 7 & Packera pseudaurea (Rydb.) W.A. Weber \& A. Löve & falsegold groundsel \\
\hline 1 & Panicum capillare L. & witchgrass \\
\hline 7 & Parnassia fimbriata Koenig & fringed grass of Parnassus \\
\hline 9 & Parnassia kotzebuei Cham. ex Spreng. & Kotzebue's grass of Parnassus \\
\hline 9 & Parnassia palustris L. var. parviflora (DC.) Boivin & smallflower grass of Parnassus \\
\hline 7 & Parnassia palustris L. var. tenuis Wahlenb. & marsh grass of Parnassus \\
\hline 3 & Pascopyrum smithii (Rydb.) A. Löve & western wheatgrass \\
\hline 7 & Pedicularis groenlandica Retz. & elephanthead lousewort \\
\hline 0 & Pennisetum glaucum (L.) R. Br. & pearl millet \\
\hline 5 & Penstemon attenuatus Dougl. ex Lindl. & sulphur penstemon \\
\hline 5 & Penstemon procerus Dougl. ex Graham & littleflower penstemon \\
\hline 9 & Petasites frigidus (L.) Fries & arctic sweet coltsfoot \\
\hline 8 & Petasites sagittatus (Banks ex Pursh) Gray & arrowleaf sweet coltsfoot \\
\hline 0 & Phalaris arundinacea L. & reed canarygrass \\
\hline 10 & Phippsia algida (C.J. Phipps) R. Br. & icegrass \\
\hline 7 & Phleum alpinum L. & alpine timothy \\
\hline 0 & Phleum pratense L. & timothy \\
\hline 5 & Phlox kelseyi Britt. & Kelsey's phlox \\
\hline 4 & Phragmites australis (Cav.) Trin. ex Steud. & common reed \\
\hline 7 & Phyllodoce empetriformis (Sm.) D. Don & pink mountainheath \\
\hline 7 & Phyllodoce glanduliflora (Hook.) Coville & yellow mountainheath \\
\hline 7 & Physostegia parviflora Nutt. ex Gray & western false dragonhead \\
\hline 4 & Picea engelmannii Parry ex Engelm. & Engelmann spruce \\
\hline 9 & Pinguicula macroceras Link & California butterwort \\
\hline 6 & Piperia unalascensis (Spreng.) Rydb. & slender-spire orchid \\
\hline 2 & Plagiobothrys scouleri (Hook. \& Arn.) I.M. Johnston & Scouler's popcornflower \\
\hline 3 & Plantago elongata Pursh & prairie plantain \\
\hline 7 & Plantago eriopoda Torr. & redwool plantain \\
\hline 0 & Plantago lanceolata L. & narrowleaf plantain \\
\hline 1 & Plantago major L. & common plantain \\
\hline 5 & Platanthera dilatata (Pursh) Lindl. ex Beck & scentbottle \\
\hline 8 & Platanthera hyperborea (L.) Lindl. & northern green orchid \\
\hline 10 & Platanthera obtusata (Banks ex Pursh) Lindl. & bluntleaved orchid \\
\hline 9 & Platanthera orbiculata (Pursh) Lindl. & lesser roundleaved orchid \\
\hline 7 & Platanthera stricta Lindl. & slender bog orchid \\
\hline 5 & Poa alpina L. & alpine bluegrass \\
\hline 4 & Poa arida Vasey & plains bluegrass \\
\hline 8 & Poa leptocoma Trin. & marsh bluegrass \\
\hline 1 & Poa palustris L. & fowl bluegrass \\
\hline 0 & Poa pratensis L. & Kentucky bluegrass \\
\hline 3 & Poa secunda J. Presl & Sandberg bluegrass \\
\hline 6 & Polemonium occidentale Greene & western polemonium \\
\hline 6 & Polygonum amphibium L. & water knotweed \\
\hline 1 & Polygonum aviculare L. & prostrate knotweed \\
\hline 6 & Polygonum bistortoides Pursh & American bistort \\
\hline 0 & Polygonum convolvulus L. & black bindweed \\
\hline
\end{tabular}




\begin{tabular}{|c|c|c|}
\hline$C$ & Scientific Name & Common Name \\
\hline 3 & Polygonum douglasii Greene & Douglas' knotweed \\
\hline 0 & Polygonum erectum L. & erect knotweed \\
\hline 1 & Polygonum lapathifolium L. & curlytop knotweed \\
\hline 1 & Polygonum persicaria $\mathrm{L}$. & spotted ladysthumb \\
\hline 4 & Polygonum polygaloides Wallich ex Meisn. & milkwort knotweed \\
\hline 7 & Polygonum viviparum $\mathrm{L}$. & alpine bistort \\
\hline 5 & Populus $\times$ acuminata Rydb. (pro sp.) & lanceleaf cottonwood \\
\hline 5 & Populus angustifolia James & narrowleaf cottonwood \\
\hline 5 & $\begin{array}{l}\text { Populus balsamifera L. ssp. trichocarpa (Torr. \& Gray ex } \\
\text { Hook.) Brayshaw }\end{array}$ & black cottonwood \\
\hline 4 & $\begin{array}{l}\text { Populus deltoides Bartr. ex Marsh. ssp. monilifera (Ait.) } \\
\text { Eckenwalder }\end{array}$ & plains cottonwood \\
\hline 5 & Populus tremuloides Michx. & quaking aspen \\
\hline 0 & Portulaca oleracea L. & little hogweed \\
\hline 7 & Potamogeton alpinus Balbis & alpine pondweed \\
\hline 10 & Potamogeton amplifolius Tuckerman & largeleaf pondweed \\
\hline 1 & Potamogeton crispus L. & curly pondweed \\
\hline 7 & Potamogeton friesii Rupr. & Fries' pondweed \\
\hline 6 & Potamogeton gramineus L. & variableleaf pondweed \\
\hline 8 & Potamogeton obtusifolius Mert. \& Koch & bluntleaf pondweed \\
\hline 7 & Potamogeton pusillus L. & small pondweed \\
\hline 6 & Potamogeton richardsonii (Benn.) Rydb. & Richardson's pondweed \\
\hline 9 & Potamogeton zosteriformis Fern. & flatstem pondweed \\
\hline 4 & Potentilla biennis Greene & biennial cinquefoil \\
\hline 6 & Potentilla diversifolia Lehm. & varileaf cinquefoil \\
\hline 6 & Potentilla glandulosa Lindl. & sticky cinquefoil \\
\hline 4 & Potentilla gracilis Dougl. ex Hook. & slender cinquefoil \\
\hline 1 & Potentilla norvegica L. & Norwegian cinquefoil \\
\hline 5 & Potentilla paradoxa Nutt. & Paradox cinquefoil \\
\hline 4 & Potentilla rivalis Nutt. & brook cinquefoil \\
\hline 5 & Primula incana M.E. Jones & silvery primrose \\
\hline 8 & Primula parryi Gray & Parry's primrose \\
\hline 2 & Prunella vulgaris L. & common selfheal \\
\hline 3 & Prunus virginiana L. & chokecherry \\
\hline 3 & Pseudognaphalium stramineum (Kunth) W.A. Weber & cottonbatting plant \\
\hline 8 & Psilocarphus brevissimus Nutt. & short woollyheads \\
\hline 4 & Puccinellia distans (Jacq.) Parl. & weeping alkaligrass \\
\hline 6 & Puccinellia nuttalliana (J.A. Schultes) A.S. Hitchc. & Nuttall's alkaligrass \\
\hline 6 & Pyrola asarifolia Michx. & liverleaf wintergreen \\
\hline 8 & Pyrola chlorantha Sw. & greenflowered wintergreen \\
\hline 4 & Pyrrocoma integrifolia (Porter ex Gray) Greene & manysted goldenweed \\
\hline 4 & Pyrrocoma lanceolata (Hook.) Greene & lanceleaf goldenweed \\
\hline 2 & Pyrrocoma uniflora (Hook.) Greene & plantain goldenweed \\
\hline 3 & Ranunculus abortivus L. & littleleaf buttercup \\
\hline 6 & Ranunculus acriformis Gray & sharpleaf buttercup \\
\hline 0 & Ranunculus acris L. & tall buttercup \\
\hline 7 & Ranunculus alismifolius Geyer ex Benth. & plantainleaf buttercup \\
\hline 4 & Ranunculus aquatilis L. & whitewater crowfoot \\
\hline 9 & Ranunculus cardiophyllus Hook. & heartleaf buttercup \\
\hline
\end{tabular}




\begin{tabular}{|c|c|c|}
\hline$C$ & Scientific Name & Common Name \\
\hline 3 & Ranunculus cymbalaria Pursh & alkali buttercup \\
\hline 7 & Ranunculus eschscholtzii Schlecht. & Eschscholtz's buttercup \\
\hline 4 & Ranunculus flammula L. & greater creeping spearwort \\
\hline 4 & Ranunculus glaberrimus Hook. & sagebrush buttercup \\
\hline 4 & Ranunculus gmelinii DC. & Gmelin's buttercup \\
\hline 9 & Ranunculus hyperboreus Rottb. & high northern buttercup \\
\hline 6 & Ranunculus inamoenus Greene & graceful buttercup \\
\hline 5 & Ranunculus macounii Britt. & Macoun's buttercup \\
\hline 8 & Ranunculus orthorhynchus Hook. & straightbeak buttercup \\
\hline 9 & Ranunculus pedatifidus Sm. & surefoot buttercup \\
\hline 7 & Ranunculus populago Greene & popular buttercup \\
\hline 9 & Ranunculus pygmaeus Wahlenb. & pygmy buttercup \\
\hline 0 & Ranunculus repens L. & creeping buttercup \\
\hline 4 & Ranunculus sceleratus L. & cursed buttercup \\
\hline 2 & Ranunculus uncinatus D. Don ex G. Don & woodland buttercup \\
\hline 9 & Ranunculus verecundus B.L. Robins. ex Piper & wetslope buttercup \\
\hline 4 & Rhamnus alnifolia L'Hér. & alderleaf buckthorn \\
\hline 8 & Rhodiola rhodantha (Gray) Jacobsen & redpod stonecrop \\
\hline 8 & Rhododendron albiflorum Hook. & Cascade azalea \\
\hline 6 & Ribes americanum P. Mill. & American black currant \\
\hline 5 & Ribes aureum Pursh & golden currant \\
\hline 7 & Ribes hudsonianum Richards. & northern black currant \\
\hline 5 & Ribes inerme Rydb. & whitestem gooseberry \\
\hline 6 & Ribes lacustre (Pers.) Poir. & prickly currant \\
\hline 6 & Ribes oxyacanthoides L. & Canadian gooseberry \\
\hline 10 & Romanzoffia sitchensis Bong. & Sitka mistmaiden \\
\hline 4 & Rorippa alpina (S. Wats.) Rydb. & alpine yellowcress \\
\hline 4 & Rorippa curvipes Greene & bluntleaf yellowcress \\
\hline 4 & Rorippa nasturtium-aquaticum (L.) Hayek & watercress \\
\hline 4 & Rorippa palustris (L.) Bess. & bog yellowcress \\
\hline 3 & Rotala ramosior (L.) Koehne & lowland rotala \\
\hline 10 & Rubus arcticus L. ssp. acaulis (Michx.) Focke & dwarf raspberry \\
\hline 7 & Rubus pubescens Raf. & dwarf red blackberry \\
\hline 5 & Rudbeckia laciniata L. & cutleaf coneflower \\
\hline 4 & Rudbeckia occidentalis Nutt. & western coneflower \\
\hline 0 & Rumex acetosella L. & common sheep sorrel \\
\hline 7 & Rumex aquaticus L. & western dock \\
\hline 0 & Rumex crispus L. & curly dock \\
\hline 6 & Rumex maritimus L. & golden dock \\
\hline 7 & Rumex salicifolius Weinm. & willow dock \\
\hline 8 & Ruppia cirrhosa (Petag.) Grande & spiral ditchgrass \\
\hline 1 & Sagina procumbens L. & birdeye pearlwort \\
\hline 3 & Sagina saginoides (L.) Karst. & arctic pearlwort \\
\hline 7 & Sagittaria cuneata Sheldon & arumleaf arrowhead \\
\hline 7 & Sagittaria latifolia Willd. & broadleaf arrowhead \\
\hline 7 & Salicornia rubra A. Nels. & red swampfire \\
\hline 7 & Salix amygdaloides Anderss. & peachleaf willow \\
\hline 7 & Salix arctica Pallas & arctic willow \\
\hline 8 & Salix barclayi Anderss. & Barclay's willow \\
\hline
\end{tabular}




\begin{tabular}{|c|c|c|}
\hline$C$ & Scientific Name & Common Name \\
\hline 10 & Salix barrattiana Hook. & Barratt's willow \\
\hline 4 & Salix bebbiana Sarg. & Bebb willow \\
\hline 6 & Salix boothii Dorn & Booth's willow \\
\hline 6 & Salix brachycarpa Nutt. & shortfruit willow \\
\hline 9 & Salix candida Flueggé ex Willd. & sageleaf willow \\
\hline 7 & Salix commutata Bebb & undergreen willow \\
\hline 5 & Salix drummondiana Barratt ex Hook. & Drummond's willow \\
\hline 4 & Salix exigua Nutt. & narrowleaf willow \\
\hline 7 & Salix farriae Ball & Farr's willow \\
\hline 0 & Salix fragilis L. & crack willow \\
\hline 6 & Salix geyeriana Anderss. & Geyer's willow \\
\hline 7 & Salix glauca L. & grayleaf willow \\
\hline 6 & Salix lemmonii Bebb & Lemmon's willow \\
\hline 5 & Salix lucida Muhl. ssp. caudata (Nutt.) E. Murr. & greenleaf willow \\
\hline 6 & Salix lutea Nutt. & yellow willow \\
\hline 5 & Salix melanopsis Nutt. & dusky willow \\
\hline 7 & Salix planifolia Pursh & diamondleaf willow \\
\hline 7 & Salix prolixa Anderss. & MacKenzie's willow \\
\hline 7 & Salix pseudomonticola Ball & false mountain willow \\
\hline 4 & Salix scouleriana Barratt ex Hook. & Scouler's willow \\
\hline 9 & Salix serissima (Bailey) Fern. & autumn willow \\
\hline 8 & Salix sitchensis Sanson ex Bong. & Sitka willow \\
\hline 7 & Salix tweedyi (Bebb ex Rose) Ball & Tweedy's willow \\
\hline 7 & Salix vestita Pursh & rock willow \\
\hline 7 & Salix wolfii Bebb & Wolf's willow \\
\hline 6 & Saxifraga adscendens L. & wedgeleaf saxifrage \\
\hline 6 & Saxifraga caespitosa $\mathrm{L}$. & tufted alpine saxifrage \\
\hline 8 & Saxifraga cernua L. & nodding saxifrage \\
\hline 8 & Saxifraga ferruginea Graham & russethair saxifrage \\
\hline 6 & Saxifraga integrifolia Hook. & wholeleaf saxifrage \\
\hline 7 & Saxifraga lyallii Engl. & redstem saxifrage \\
\hline 7 & Saxifraga mertensiana Bong. & wood saxifrage \\
\hline 7 & Saxifraga nidifica Greene & peak saxifrage \\
\hline 6 & Saxifraga occidentalis S. Wats. & Alberta saxifrage \\
\hline 7 & Saxifraga odontoloma Piper & brook saxifrage \\
\hline 6 & Saxifraga oregana T.J. Howell & Oregon saxifrage \\
\hline 7 & Saxifraga rhomboidea Greene & diamondleaf saxifrage \\
\hline 8 & Saxifraga rivularis L. & weak saxifrage \\
\hline 10 & Scheuchzeria palustris L. & rannoch-rush \\
\hline 5 & Schoenoplectus acutus (Muhl. ex Bigelow) A.\& D. Löve & hardstem bulrush \\
\hline 8 & Schoenoplectus heterochaetus (Chase) Soják & slender bulrush \\
\hline 6 & Schoenoplectus maritimus (L.) Lye & cosmopolitan bulrush \\
\hline 6 & Schoenoplectus pungens (Vahl) Palla & common threesquare \\
\hline 9 & Schoenoplectus subterminalis (Torr.) Soják & swaying bulrush \\
\hline 6 & Schoenoplectus tabernaemontani (K.C. Gmel.) Palla & softstem bulrush \\
\hline 1 & Scirpus cyperinus (L.) Kunth & woolgrass \\
\hline 5 & Scirpus microcarpus J.\& K. Presl & panicled bulrush \\
\hline 9 & Scirpus nevadensis S. Wats. & Nevada bulrush \\
\hline 4 & Scrophularia lanceolata Pursh & lanceleaf figwort \\
\hline
\end{tabular}




\begin{tabular}{|c|c|c|}
\hline$C$ & Scientific Name & Common Name \\
\hline 6 & Scutellaria galericulata L. & marsh skullcap \\
\hline 7 & Senecio crassulus Gray & thickleaf ragwort \\
\hline 5 & Senecio hydrophiloides Rydb. & tall groundwel \\
\hline 5 & Senecio hydrophilus Nutt. & water ragwort \\
\hline 7 & Senecio integerrimus Nutt. & lambstongue ragwort \\
\hline 5 & Senecio serra Hook. & tall ragwort \\
\hline 6 & Senecio sphaerocephalus Greene & ballhead ragwort \\
\hline 5 & Senecio triangularis Hook. & arrowleaf ragwort \\
\hline 0 & Senecio vulgaris L. & old-man-in-the-Spring \\
\hline 3 & Sidalcea oregana (Nutt. ex Torr. \& Gray) Gray & Oregon checkerbloom \\
\hline 6 & Silene menziesii Hook. & Menzies' campion \\
\hline 6 & Silene uralensis (Rupr.) Bocquet & apetalous catchfly \\
\hline 6 & Sisyrinchium idahoense Bickn. & Idaho blue-eyed grass \\
\hline 6 & Sisyrinchium montanum Greene & strict blue-eyed grass \\
\hline 8 & Sisyrinchium septentrionale Bickn. & northern blue-eyed grass \\
\hline 7 & Sium suave Walt. & hemlock waterparsnip \\
\hline 8 & Smilax lasioneura Hook. & Blue Ridge carrionflower \\
\hline 1 & Solanum dulcamara L. & climbing nightshade \\
\hline 3 & Solidago canadensis L. & Canada goldenrod \\
\hline 6 & Solidago gigantea Ait. & giant goldenrod \\
\hline 0 & Sonchus arvensis L. & field sowthistle \\
\hline 0 & Sonchus asper (L.) Hill & spiny sowthistle \\
\hline 7 & Sparganium angustifolium Michx. & narrowleaf bur-reed \\
\hline 7 & Sparganium eurycarpum Engelm. ex Gray & broadfruit bur-reed \\
\hline 6 & Sparganium natans L. & small bur-reed \\
\hline 6 & Spartina gracilis Trin. & alkali cordgrass \\
\hline 6 & Spartina pectinata Bosc ex Link & prairie cordgrass \\
\hline 8 & Spergularia salina J.\& K. Presl & salt sandspurry \\
\hline 7 & Sphenopholis obtusata (Michx.) Scribn. & prairie wedgescale \\
\hline 5 & Spiraea douglasii Hook. & rose spirea \\
\hline 6 & Spiranthes romanzoffiana Cham. & hooded ladies'-tresses \\
\hline 7 & Spirodela polyrrhiza (L.) Schleid. & common duckmeat \\
\hline 7 & Sporobolus airoides (Torr.) Torr. & alkali sacaton \\
\hline 6 & Stachys pilosa Nutt. & hairy hedgenettle \\
\hline 6 & Stellaria borealis Bigelow & boreal starwort \\
\hline 6 & Stellaria calycantha (Ledeb.) Bong. & northern starwort \\
\hline 5 & Stellaria crassifolia Ehrh. & fleshy starwort \\
\hline 4 & Stellaria crispa Cham. \& Schlecht. & curled starwort \\
\hline 6 & Stellaria longifolia Muhl. ex Willd. & longleaf starwort \\
\hline 7 & Stellaria longipes Goldie & longstalk starwort \\
\hline 7 & Stellaria umbellata Turcz. ex Kar. \& Kir. & umbrella starwort \\
\hline 7 & Stenanthium occidentale Gray & western featherbells \\
\hline 7 & Streptopus amplexifolius (L.) DC. & claspleaf twistedstalk \\
\hline 5 & Stuckenia pectinatus (L.) Boerner & sago pondweed \\
\hline 3 & Suaeda calceoliformis (Hook.) Moq. & Pursh seepweed \\
\hline 6 & Suaeda moquinii (Torr.) Greene & Mojave seablite \\
\hline 7 & Suksdorfia ranunculifolia (Hook.) Engl. & buttercup suksdorfia \\
\hline 8 & Suksdorfia violacea Gray & violet suksdorfia \\
\hline 7 & Swertia perennis L. & felwort \\
\hline
\end{tabular}




\begin{tabular}{|c|c|c|}
\hline$C$ & Scientific Name & Common Name \\
\hline 3 & Symphoricarpos albus (L.) Blake & common snowberry \\
\hline 4 & Symphoricarpos occidentalis Hook. & western snowberry \\
\hline 2 & Symphyotrichum chilense (Nees) Nesom & Pacific aster \\
\hline 5 & Symphyotrichum ciliatum (Ledeb.) Nesom & rayless alkali aster \\
\hline 5 & Symphyotrichum eatonii (Gray) Nesom & Eaton's aster \\
\hline 6 & $\begin{array}{l}\text { Symphyotrichum ericoides (L.) Nesom var. pansum (Blake) } \\
\text { Nesom }\end{array}$ & manyflowered aster \\
\hline 5 & Symphyotrichum foliaceum (DC.) Nesom & alpine leafybract aster \\
\hline 4 & Symphyotrichum frondosum (Nutt.) Nesom & short-rayed alkalai aster \\
\hline 4 & Symphyotrichum lanceolatum (Willd.) Nesom & white panicle aster \\
\hline 5 & Symphyotrichum spathulatum (Lindl.) Nesom & western mountain aster \\
\hline 6 & Symphyotrichum subspicatum (Nees) Nesom & Douglas aster \\
\hline 0 & Tamarix chinensis Lour. & fivestamen tamarisk \\
\hline 0 & Taraxacum officinale G.H. Weber ex Wiggers & common dandelion \\
\hline 9 & Thalictrum alpinum L. & alpine meadow-rue \\
\hline 5 & Thalictrum dasycarpum Fisch. \& Avé-Lall. & purple meadow-rue \\
\hline 5 & Thalictrum occidentale Gray & western meadow-rue \\
\hline 5 & Thalictrum sparsiflorum Turcz. ex Fisch. \& C.A. Mey. & fewflower meadow-rue \\
\hline 6 & Thermopsis montana Nutt. & mountain goldenbanner \\
\hline 7 & Thuja plicata Donn ex D. Don & western red cedar \\
\hline 7 & Tofieldia glutinosa (Michx.) Pers. & sticky tofieldia \\
\hline 7 & Torreyochloa pallida (Torr.) Church & pale false mannagrass \\
\hline 4 & Toxicodendron rydbergii (Small ex Rydb.) Greene & western poison ivy \\
\hline 8 & Trautvetteria caroliniensis (Walt.) Vail & Carolina bugbane \\
\hline 0 & Tribulus terrestris L. & puncturevine \\
\hline 4 & Trifolium beckwithii Brewer ex S. Wats. & Beckwith's clover \\
\hline 0 & Trifolium fragiferum L. & strawberry clover \\
\hline 6 & Trifolium longipes Nutt. & longstalk clover \\
\hline 1 & Trifolium microcephalum Pursh & smallhead clover \\
\hline 7 & Trifolium parryi Gray & Parry's clover \\
\hline 0 & Trifolium repens L. & white clover \\
\hline 8 & Triglochin maritimum L. & seaside arrowgrass \\
\hline 7 & Triglochin palustre L. & marsh arrowgrass \\
\hline 1 & Triodanis perfoliata (L.) Nieuwl. & clasping Venus' looking-glass \\
\hline 0 & Tripleurospermum perforata (Merat) M. Lainz & scentless false mayweed \\
\hline 7 & Trollius laxus Salisb. & American globeflower \\
\hline 7 & Typha angustifolia L. & narrowleaf cattail \\
\hline 3 & Typha latifolia L. & broadleaf cattail \\
\hline 3 & Urtica dioica $\mathrm{L}$. & stinging nettle \\
\hline 10 & Utricularia minor L. & lesser bladderwort \\
\hline 8 & Vaccinium uliginosum L. & bog blueberry \\
\hline 7 & Vahlodea atropurpurea (Wahlenb.) Fries ex Hartman & mountain hairgrass \\
\hline 5 & Valeriana dioica L. & marsh valerian \\
\hline 7 & Valeriana edulis Nutt. ex Torr. \& Gray & tobacco root \\
\hline 7 & Valeriana occidentalis Heller & western valerian \\
\hline 7 & Valeriana sitchensis Bong. & Sitka valerian \\
\hline 7 & Veratrum viride Ait. & green false hellebore \\
\hline 5 & Veronica americana Schwein. ex Benth. & American speedwell \\
\hline 4 & Veronica anagallis-aquatica $\mathrm{L}$. & water speedwell \\
\hline
\end{tabular}




\begin{tabular}{lll}
\hline C & Scientific Name & Common Name \\
\hline 7 & Veronica cusickii Gray & Cusick's speedwell \\
4 & Veronica peregrina L. & neckweed \\
6 & Veronica scutellata L. & skullcap speedwell \\
2 & Veronica serpyllifolia L. & thymeleaf speedwell \\
7 & Veronica wormskjoldii Roemer \& J.A. Schultes & American alpine speedwell \\
8 & Viburnum edule (Michx.) Raf. & squashberry \\
5 & Viola adunca Sm. & hookedspur violet \\
8 & Viola macloskeyi Lloyd & small white violet \\
8 & Viola nephrophylla Greene & northern bog violet \\
7 & Viola palustris L. & marsh violet \\
8 & Viola renifolia Gray & white violet \\
5 & Vitis riparia Michx. & riverbank grape \\
7 & Wolffia brasiliensis Weddell & Brazilian watermeal \\
7 & Wolffia columbiana Karst. & Columbian watermeal \\
2 & Wyethia helianthoides Nutt. & sunflower mule-ears \\
2 & Xanthium strumarium L. & rough cockleburr \\
8 & Zannichellia palustris L. & horned pondweed \\
5 & Zigadenus venenosus S. Wats. & meadow deathcamas \\
6 & Zizania palustris L. & northern wildrice \\
7 & Zizia aptera (Gray) Fern. & meadow zizia \\
\hline
\end{tabular}





\section{APPENDix B. List AND ATTRIBUTES OF SAMPLED PLANT SPECIES.}



Appendix B. List and attributes of sampled plant species.

\begin{tabular}{|c|c|c|c|c|c|c|}
\hline Scientific Name & Common Name & $\begin{array}{l}\text { Growth } \\
\text { Form }^{\mathrm{a}}\end{array}$ & Duration $^{\mathrm{b}}$ & Nativity $^{\mathrm{c}}$ & $\begin{array}{l}\text { Wetland } \\
\text { Indicator } \\
\text { Status } \\
\end{array}$ & $\begin{array}{c}\text { Bank } \\
\text { Stability } \\
\text { Rating }^{\text {e }} \\
\end{array}$ \\
\hline Achillea millefolium L. & common yarrow & $\mathrm{F}$ & $\mathrm{P}$ & $\mathrm{N}$ & FACU & poor \\
\hline Achnatherum nelsonii (Scribn.) Barkworth & Columbia needlegrass & G & $\mathrm{P}$ & $\mathrm{N}$ & UPL & $\mathrm{n} / \mathrm{a}$ \\
\hline Actaea rubra (Ait.) Willd. & red baneberry & $\mathrm{F}$ & $\mathrm{P}$ & $\mathrm{N}$ & UPL & poor \\
\hline Agoseris glauca (Pursh) Raf. & pale agoseris & $\mathrm{F}$ & $\mathrm{P}$ & $\mathrm{N}$ & FAC & poor \\
\hline Agrostis gigantea Roth & redtop & $\mathrm{G}$ & $P$ & $\mathrm{E}$ & FAC & fair \\
\hline Agrostis scabra Willd. & rough bentgrass & G & $\mathrm{P}$ & $\mathrm{N}$ & FAC & fair \\
\hline Allium brevistylum S. Wats. & shortstyle onion & $\mathrm{F}$ & $P$ & $\mathrm{~N}$ & UPL & poor \\
\hline Allium schoenoprasum L. & wild chives & $\mathrm{F}$ & $P$ & $\mathrm{~N}$ & FACW & poor \\
\hline Alnus incana (L.) Moench & gray alder & S & $\mathrm{P}$ & $\mathrm{N}$ & FACW & good \\
\hline Alopecurus aequalis Sobol. & shortawn foxtail & G & $\mathrm{P}$ & $\mathrm{N}$ & OBL & poor \\
\hline Alopecurus alpinus Sm. & boreal alopecurus & $\mathrm{G}$ & $P$ & $\mathrm{~N}$ & FACW & fair \\
\hline Alopecurus pratensis L. & meadow foxtail & $\mathrm{G}$ & $\mathrm{P}$ & $\mathrm{E}$ & FACW & fair \\
\hline Androsace filiformis Retz. & filiform rockjasmine & $\mathrm{F}$ & $\mathrm{A} / \mathrm{B}$ & $\mathrm{N}$ & FACW & poor \\
\hline Angelica arguta Nutt. & Lyall's angelica & $\mathrm{F}$ & $\mathrm{P}$ & $\mathrm{N}$ & FACW & fair \\
\hline Antennaria corymbosa E. Nels. & flat-top pussytoes & $\mathrm{F}$ & $\mathrm{P}$ & $\mathrm{N}$ & FAC & poor \\
\hline Antennaria microphylla Rydb. & littleleaf pussytoes & $\mathrm{F}$ & $\mathrm{P}$ & $\mathrm{N}$ & UPL & poor \\
\hline Argentina anserina (L.) Rydb. & silverweed cinquefoil & $\mathrm{F}$ & $P$ & $\mathrm{~N}$ & OBL & fair \\
\hline Arnica mollis Hook. & hairy arnica & $\mathrm{F}$ & $\mathrm{P}$ & $\mathrm{N}$ & FAC & poor \\
\hline Artemisia cana Pursh & silver sagebrush & S & $\mathrm{P}$ & $\mathrm{N}$ & FAC & fair \\
\hline Artemisia frigida Willd. & prairie sagewort & $\mathrm{S}$ & $\mathrm{P}$ & $\mathrm{N}$ & UPL & $\mathrm{n} / \mathrm{a}$ \\
\hline Artemisia ludoviciana Nutt. & white sagebrush & $\mathrm{S}$ & $\mathrm{P}$ & $\mathrm{N}$ & FACU & $\mathrm{n} / \mathrm{a}$ \\
\hline Artemisia tridentata Nutt. ssp. tridentata & basin big sagebrush & S & $P$ & $\mathrm{~N}$ & FACU & poor \\
\hline Artemisia tridentata Nutt. ssp. vaseyana (Rydb.) Beetle & mountain big sagebrush & S & $P$ & $\mathrm{~N}$ & UPL & $\mathrm{n} / \mathrm{a}$ \\
\hline Artemisia tridentata Nutt. ssp. wyomingensis Beetle \& Young & Wyoming big sagebrush & S & $\mathrm{P}$ & $\mathrm{N}$ & UPL & $\mathrm{n} / \mathrm{a}$ \\
\hline Astragalus agrestis Dougl. ex G. Don & purple milkvetch & $\mathrm{F}$ & $\mathrm{P}$ & $\mathrm{N}$ & FACW & poor \\
\hline Beckmannia syzigachne (Steud.) Fern. & American sloughgrass & G & $\mathrm{A} / \mathrm{B}$ & $\mathrm{N}$ & OBL & fair \\
\hline Bromus ciliatus L. & fringed brome & G & $\mathrm{P}$ & $\mathrm{N}$ & FAC & fair \\
\hline Bromus marginatus Nees ex Steud. & mountain brome & G & $\mathrm{P}$ & $\mathrm{N}$ & UPL & $\mathrm{n} / \mathrm{a}$ \\
\hline Calamagrostis canadensis (Michx.) Beauv. & bluejoint & G & $P$ & $\mathrm{~N}$ & FACW & excellent \\
\hline Calamagrostis stricta (Timm) Koel. & slimstem reedgrass & $\mathrm{G}$ & $\mathrm{P}$ & $\mathrm{N}$ & FACW & excellent \\
\hline Campanula rotundifolia $\mathrm{L}$. & bluebell bellflower & $\mathrm{F}$ & $\mathrm{P}$ & $\mathrm{N}$ & FACU & $\mathrm{n} / \mathrm{a}$ \\
\hline Canadanthus modestus (Lindl.) Nesom & giant mountain aster & $\mathrm{F}$ & $\mathrm{P}$ & $\mathrm{N}$ & FAC & poor \\
\hline
\end{tabular}




\begin{tabular}{|c|c|c|c|c|c|c|}
\hline Scientific Name & Common Name & $\begin{array}{c}\text { Growth } \\
\text { Form }^{\mathrm{a}} \\
\end{array}$ & Duration $^{\mathrm{b}}$ & Nativity $^{\mathrm{c}}$ & $\begin{array}{l}\text { Wetland } \\
\text { Indicator } \\
\text { Status }^{\mathrm{d}} \\
\end{array}$ & $\begin{array}{c}\text { Bank } \\
\text { Stability } \\
\text { Rating } \\
\end{array}$ \\
\hline Cardamine oligosperma Nutt. & little western bittercress & $\mathrm{F}$ & $\mathrm{A} / \mathrm{B}$ & $\mathrm{N}$ & FACW & poor \\
\hline Cardamine pensylvanica Muhl. ex Willd. & Pennsylvania bittercress & $\mathrm{F}$ & $\mathrm{A} / \mathrm{B}$ & $\mathrm{N}$ & FACW & poor \\
\hline Carex aquatilis Wahlenb. & water sedge & $\mathrm{G}$ & $\mathrm{P}$ & $\mathrm{N}$ & OBL & excellent \\
\hline Carex aurea Nutt. & golden sedge & G & $\mathrm{P}$ & $\mathrm{N}$ & FACW & fair \\
\hline Carex canescens L. & silvery sedge & G & $\mathrm{P}$ & $\mathrm{N}$ & FACW & good \\
\hline Carex disperma Dewey & softleaf sedge & $\mathrm{G}$ & $\mathrm{P}$ & $\mathrm{N}$ & FACW & fair \\
\hline Carex foenea Willd. & dryspike sedge & G & $\mathrm{P}$ & $\mathrm{N}$ & UPL & fair \\
\hline Carex lenticularis Michx. & lakeshore sedge & $\mathrm{G}$ & $\mathrm{P}$ & $\mathrm{N}$ & FACW & good \\
\hline Carex microptera Mackenzie & smallwing sedge & G & $\mathrm{P}$ & $\mathrm{N}$ & FAC & good \\
\hline Carex nebrascensis Dewey & Nebraska sedge & G & $\mathrm{P}$ & $\mathrm{N}$ & OBL & excellent \\
\hline Carex norvegica Retz. & Norway sedge & G & $\mathrm{P}$ & $\mathrm{N}$ & FACW & $\mathrm{n} / \mathrm{a}$ \\
\hline Carex pellita Muhl ex Willd. & woolly sedge & G & $\mathrm{P}$ & $\mathrm{N}$ & OBL & excellent \\
\hline Carex praegracilis W. Boott & clustered field sedge & G & $\mathrm{P}$ & $\mathrm{N}$ & FACW & excellent \\
\hline Carex praticola Rydb. & meadow sedge & G & $\mathrm{P}$ & $\mathrm{N}$ & FACW & $\mathrm{n} / \mathrm{a}$ \\
\hline Carex simulata Mackenzie & analogue sedge & $\mathrm{G}$ & $\mathrm{P}$ & $\mathrm{N}$ & OBL & excellent \\
\hline Carex utriculata Boott & Northwest Territory sedge & G & $\mathrm{P}$ & $\mathrm{N}$ & OBL & excellent \\
\hline Carex vesicaria L. & blister sedge & $\mathrm{G}$ & $\mathrm{P}$ & $\mathrm{N}$ & OBL & excellent \\
\hline Carex L. & sedge & $\mathrm{G}$ & $\mathrm{P}$ & $\mathrm{N}$ & $\mathrm{n} / \mathrm{a}$ & fair \\
\hline Castilleja miniata Dougl. ex Hook. & giant red Indian paintbrush & $\mathrm{F}$ & $\mathrm{P}$ & $\mathrm{N}$ & FAC & poor \\
\hline Catabrosa aquatica (L.) Beauv. & water whorlgrass & $\mathrm{G}$ & $\mathrm{P}$ & $\mathrm{N}$ & OBL & fair \\
\hline Cerastium nutans Raf. & nodding chickweed & $\mathrm{F}$ & $\mathrm{A} / \mathrm{B}$ & $\mathrm{N}$ & FACU & poor \\
\hline Chamerion angustifolium (L.) Holub & fireweed & $\mathrm{F}$ & $\mathrm{P}$ & $\mathrm{N}$ & FACU & poor \\
\hline Cirsium arvense (L.) Scop. & Canada thistle & $\mathrm{F}$ & $\mathrm{P}$ & $\mathrm{E}$ & FACU & fair \\
\hline Cirsium scariosum Nutt. & meadow thistle & $\mathrm{F}$ & $\mathrm{A} / \mathrm{B}$ & $\mathrm{N}$ & UPL & poor \\
\hline Cirsium vulgare (Savi) Ten. & bull thistle & $\mathrm{F}$ & $\mathrm{A} / \mathrm{B}$ & $\mathrm{E}$ & FACU & poor \\
\hline Collomia linearis Nutt. & tiny trumpet & $\mathrm{F}$ & $\mathrm{A} / \mathrm{B}$ & $\mathrm{N}$ & FACU & poor \\
\hline Cynoglossum officinale L. & gypsyflower & $\mathrm{F}$ & $\mathrm{A} / \mathrm{B}$ & $\mathrm{E}$ & FACU & poor \\
\hline Danthonia intermedia Vasey & timber oatgrass & G & $\mathrm{P}$ & $\mathrm{N}$ & FACU & $\mathrm{n} / \mathrm{a}$ \\
\hline Dasiphora floribunda (Pursh) Kartesz, comb. nov. ined. & shrubby cinquefoil & $\mathrm{S}$ & $\mathrm{P}$ & $\mathrm{N}$ & FAC & fair \\
\hline Deschampsia caespitosa (L.) Beauv. & tufted hairgrass & G & $\mathrm{P}$ & $\mathrm{N}$ & FACW & fair \\
\hline Descurainia sophia (L.) Webb ex Prantl & herb sophia & $\mathrm{F}$ & $\mathrm{A} / \mathrm{B}$ & $\mathrm{E}$ & UPL & $\mathrm{n} / \mathrm{a}$ \\
\hline Eleocharis palustris (L.) Roemer \& J.A. Schultes & common spikerush & G & $\mathrm{P}$ & $\mathrm{N}$ & OBL & excellent \\
\hline Eleocharis quinqueflora (F.X. Hartmann) Schwarz & fewflower spikerush & G & $\mathrm{P}$ & $\mathrm{N}$ & OBL & $\mathrm{n} / \mathrm{a}$ \\
\hline
\end{tabular}

Appendix B - 2 


\begin{tabular}{|c|c|c|c|c|c|c|}
\hline Scientific Name & Common Name & $\begin{array}{c}\text { Growth } \\
\text { Form }^{\mathrm{a}}\end{array}$ & Duration $^{\mathrm{b}}$ & Nativity $^{\mathrm{c}}$ & $\begin{array}{l}\text { Wetland } \\
\text { Indicator } \\
\text { Status }^{\mathrm{d}} \\
\end{array}$ & $\begin{array}{c}\text { Bank } \\
\text { Stability } \\
\text { Rating }\end{array}$ \\
\hline Elymus repens (L.) Gould & quackgrass & G & $\mathrm{P}$ & $\mathrm{E}$ & FACU & excellent \\
\hline Elymus trachycaulus (Link) Gould ex Shinners & slender wheatgrass & G & $\mathrm{P}$ & $\mathrm{N}$ & FAC & $\mathrm{n} / \mathrm{a}$ \\
\hline Epilobium anagallidifolium Lam. & pimpernel willowherb & $\mathrm{F}$ & $\mathrm{P}$ & $\mathrm{N}$ & FACW & poor \\
\hline Epilobium ciliatum Raf. & fringed willowherb & $\mathrm{F}$ & $\mathrm{P}$ & $\mathrm{N}$ & FACW & poor \\
\hline Epilobium palustre L. & marsh willowherb & $\mathrm{F}$ & $\mathrm{P}$ & $\mathrm{N}$ & OBL & poor \\
\hline Equisetum arvense L. & field horsetail & $\mathrm{F}$ & $\mathrm{P}$ & $\mathrm{N}$ & FAC & good \\
\hline Equisetum laevigatum A. Braun & smooth horsetail & $\mathrm{F}$ & $\mathrm{P}$ & $\mathrm{N}$ & FACW & fair \\
\hline Ericameria nauseosa (Pallas ex Pursh) Nesom \& Baird & rubber rabbitbrush & $\mathrm{S}$ & $\mathrm{P}$ & $\mathrm{N}$ & UPL & $\mathrm{n} / \mathrm{a}$ \\
\hline Erigeron gracilis Rydb. & quill fleabane & $\mathrm{F}$ & $\mathrm{P}$ & $\mathrm{N}$ & UPL & $\mathrm{n} / \mathrm{a}$ \\
\hline Erysimum cheiranthoides L. & wormseed wallflower & $\mathrm{F}$ & $\mathrm{A} / \mathrm{B}$ & $\mathrm{E}$ & FACU & poor \\
\hline Festuca idahoensis Elmer & Idaho fescue & G & $\mathrm{P}$ & $\mathrm{N}$ & FACU & $\mathrm{n} / \mathrm{a}$ \\
\hline Festuca rubra L. & red fescue & G & $\mathrm{P}$ & $\mathrm{N}$ & FAC & good \\
\hline Fragaria virginiana Duchesne & Virginia strawberry & $\mathrm{F}$ & $\mathrm{P}$ & $\mathrm{N}$ & FACU & poor \\
\hline Galium boreale L. & northern bedstraw & $\mathrm{F}$ & $\mathrm{P}$ & $\mathrm{N}$ & FACU & poor \\
\hline Galium trifidum L. & threepetal bedstraw & $\mathrm{F}$ & $\mathrm{P}$ & $\mathrm{N}$ & FACW & poor \\
\hline Galium triflorum Michx. & fragrant bedstraw & $\mathrm{F}$ & $\mathrm{P}$ & $\mathrm{N}$ & FACU & poor \\
\hline Gentiana affinis Griseb. & pleated gentian & $\mathrm{F}$ & $\mathrm{P}$ & $\mathrm{N}$ & FACU & $\mathrm{n} / \mathrm{a}$ \\
\hline Geranium richardsonii Fisch. \& Trautv. & Richardson's geranium & $\mathrm{F}$ & $\mathrm{P}$ & $\mathrm{N}$ & FAC & poor \\
\hline Geranium viscosissimum Fisch. \& C.A. Mey. ex C.A. Mey. & sticky purple geranium & $\mathrm{F}$ & $\mathrm{P}$ & $\mathrm{N}$ & FACU & poor \\
\hline Geum macrophyllum Willd. & largeleaf avens & $\mathrm{F}$ & $\mathrm{P}$ & $\mathrm{N}$ & FACW & poor \\
\hline Geum rivale $\mathrm{L}$. & purple avens & $\mathrm{F}$ & $\mathrm{P}$ & $\mathrm{N}$ & FACW & $\mathrm{n} / \mathrm{a}$ \\
\hline Geum triflorum Pursh & old man's whiskers & $\mathrm{F}$ & $\mathrm{P}$ & $\mathrm{N}$ & FACU & $\mathrm{n} / \mathrm{a}$ \\
\hline Glyceria grandis S. Wats. & American mannagrass & G & $\mathrm{P}$ & $\mathrm{N}$ & OBL & fair \\
\hline Glyceria striata (Lam.) A.S. Hitchc. & fowl mannagrass & G & $\mathrm{P}$ & $\mathrm{N}$ & OBL & fair \\
\hline Heracleum maximum Bartr. & common cowparsnip & $\mathrm{F}$ & $\mathrm{P}$ & $\mathrm{N}$ & FAC & fair \\
\hline Hordeum brachyantherum Nevski & meadow barley & G & $\mathrm{P}$ & $\mathrm{N}$ & FACW & fair \\
\hline Hordeum jubatum L. & foxtail barley & G & $\mathrm{P}$ & $\mathrm{N}$ & FAC & poor \\
\hline Iris missouriensis Nutt. & Rocky Mountain iris & $\mathrm{F}$ & $\mathrm{P}$ & $\mathrm{N}$ & FACW & fair \\
\hline Juncus balticus Willd. & Baltic rush & G & $\mathrm{P}$ & $\mathrm{N}$ & OBL & excellent \\
\hline Juncus ensifolius Wikstr. & swordleaf rush & G & $\mathrm{P}$ & $\mathrm{N}$ & FACW & poor \\
\hline Juncus longistylis Torr. & longstyle rush & G & $\mathrm{P}$ & $\mathrm{N}$ & FACW & fair \\
\hline Juncus mertensianus Bong. & Mertens' rush & G & $\mathrm{P}$ & $\mathrm{N}$ & OBL & fair \\
\hline Juncus L. & rush & $\mathrm{G}$ & $\mathrm{P}$ & $\mathrm{N}$ & $\mathrm{n} / \mathrm{a}$ & $\mathrm{n} / \mathrm{a}$ \\
\hline
\end{tabular}




\begin{tabular}{|c|c|c|c|c|c|c|}
\hline Scientific Name & Common Name & $\begin{array}{l}\text { Growth } \\
\text { Form }^{\mathrm{a}}\end{array}$ & Duration $^{\mathrm{b}}$ & Nativity $^{\mathrm{c}}$ & $\begin{array}{l}\text { Wetland } \\
\text { Indicator } \\
\text { Status }^{\mathrm{d}}\end{array}$ & $\begin{array}{c}\text { Bank } \\
\text { Stability } \\
\text { Rating }\end{array}$ \\
\hline Leymus cinereus (Scribn. \& Merr.) A. Löve & basin wildrye & G & $\mathrm{P}$ & $\mathrm{N}$ & FAC & $\mathrm{n} / \mathrm{a}$ \\
\hline Ligusticum tenuifolium S. Wats. & Idaho licorice-root & $\mathrm{F}$ & $\mathrm{P}$ & $\mathrm{N}$ & FACW & poor \\
\hline Lolium pratense (Huds.) S.J. Darbyshire & meadow ryegrass & G & $\mathrm{P}$ & $\mathrm{E}$ & FACU & $\mathrm{n} / \mathrm{a}$ \\
\hline Lupinus polyphyllus Lindl. & bigleaf lupine & $\mathrm{F}$ & $\mathrm{P}$ & $\mathrm{N}$ & FAC & poor \\
\hline Lupinus sericeus Pursh & silky lupine & $\mathrm{F}$ & $\mathrm{P}$ & $\mathrm{N}$ & UPL & $\mathrm{n} / \mathrm{a}$ \\
\hline Luzula parviflora (Ehrh.) Desv. & smallflowered woodrush & G & $\mathrm{P}$ & $\mathrm{N}$ & FAC & poor \\
\hline Lycopus asper Greene & rough bugleweed & $\mathrm{F}$ & $\mathrm{P}$ & $\mathrm{N}$ & OBL & poor \\
\hline Maianthemum stellatum (L.) Link & starry false lily of the vally & $\mathrm{F}$ & $\mathrm{P}$ & $\mathrm{N}$ & FAC & poor \\
\hline Mentha arvensis L. & wild mint & $\mathrm{F}$ & $\mathrm{P}$ & $\mathrm{N}$ & FACW & poor \\
\hline Mertensia ciliata (James ex Torr.) G. Don & tall fringed bluebells & $\mathrm{F}$ & $\mathrm{P}$ & $\mathrm{N}$ & FACW & fair \\
\hline Mimulus guttatus DC. & seep monkeyflower & $\mathrm{F}$ & $\mathrm{A} / \mathrm{B}$ & $\mathrm{N}$ & OBL & poor \\
\hline Moehringia lateriflora (L.) Fenzl & bluntleaf sandwort & $\mathrm{F}$ & $\mathrm{P}$ & $\mathrm{N}$ & FAC & poor \\
\hline Montia chamissoi (Ledeb. ex Spreng.) Greene & water minerslettuce & $\mathrm{F}$ & $\mathrm{P}$ & $\mathrm{N}$ & OBL & poor \\
\hline Muhlenbergia richardsonis (Trin.) Rydb. & mat muhly & G & $\mathrm{P}$ & $\mathrm{N}$ & FAC & poor \\
\hline Osmorhiza berteroi DC. & sweetcicely & $\mathrm{F}$ & $\mathrm{P}$ & $\mathrm{N}$ & UPL & poor \\
\hline Packera pseudaurea (Rydb.) W.A. Weber \& A. Löve & falsegold groundsel & $\mathrm{F}$ & $\mathrm{P}$ & $\mathrm{N}$ & FACW & fair \\
\hline Parnassia fimbriata Koenig & fringed grass of Parnassus & $\mathrm{F}$ & $\mathrm{P}$ & $\mathrm{N}$ & OBL & poor \\
\hline Pascopyrum smithii (Rydb.) A. Löve & western wheatgrass & G & $\mathrm{P}$ & $\mathrm{N}$ & FACU & good \\
\hline Pedicularis groenlandica Retz. & elephanthead lousewort & $\mathrm{F}$ & $\mathrm{P}$ & $\mathrm{N}$ & OBL & $\mathrm{n} / \mathrm{a}$ \\
\hline Penstemon procerus Dougl. ex Graham & littleflower penstemon & $\mathrm{F}$ & $\mathrm{P}$ & $\mathrm{N}$ & UPL & $\mathrm{n} / \mathrm{a}$ \\
\hline Phleum alpinum L. & alpine timothy & G & $\mathrm{P}$ & $\mathrm{N}$ & FAC & fair \\
\hline Phleum pratense L. & timothy & G & $\mathrm{P}$ & $\mathrm{N}$ & FAC & fair \\
\hline Picea engelmannii Parry ex Engelm. & Engelmann spruce & $\mathrm{T}$ & $\mathrm{P}$ & $\mathrm{N}$ & FAC & fair \\
\hline Plantago major L. & common plantain & $\mathrm{F}$ & $\mathrm{P}$ & $\mathrm{N}$ & FAC & poor \\
\hline Platanthera stricta Lindl. & slender bog orchid & $\mathrm{F}$ & $\mathrm{P}$ & $\mathrm{N}$ & FACW & poor \\
\hline Poa arida Vasey & plains bluegrass & G & $\mathrm{P}$ & $\mathrm{N}$ & FAC & fair \\
\hline Poa palustris L. & fowl bluegrass & G & $\mathrm{P}$ & $\mathrm{E}$ & FAC & fair \\
\hline Poa pratensis L. & Kentucky bluegrass & G & $\mathrm{P}$ & $\mathrm{E}$ & FAC & poor \\
\hline Poa secunda J. Presl & Sandberg bluegrass & G & $\mathrm{P}$ & $\mathrm{N}$ & FACU & $\mathrm{n} / \mathrm{a}$ \\
\hline Polemonium occidentale Greene & western polemonium & $\mathrm{F}$ & $\mathrm{P}$ & $\mathrm{N}$ & FACW & poor \\
\hline Polygonum aviculare L. & prostrate knotweed & $\mathrm{F}$ & $\mathrm{A} / \mathrm{B}$ & $\mathrm{E}$ & FACW & $\mathrm{n} / \mathrm{a}$ \\
\hline Polygonum douglasii Greene & Douglas' knotweed & $\mathrm{F}$ & $\mathrm{A} / \mathrm{B}$ & $\mathrm{N}$ & FACU & $\mathrm{n} / \mathrm{a}$ \\
\hline Populus tremuloides Michx. & quaking aspen & $\mathrm{T}$ & $\mathrm{P}$ & $\mathrm{N}$ & FAC & good \\
\hline
\end{tabular}

Appendix B - 4 


\begin{tabular}{|c|c|c|c|c|c|c|}
\hline Scientific Name & Common Name & $\begin{array}{l}\text { Growth } \\
\text { Form }^{\mathrm{a}}\end{array}$ & Duration $^{\mathrm{b}}$ & Nativity $^{\mathrm{c}}$ & $\begin{array}{l}\text { Wetland } \\
\text { Indicator } \\
\text { Status }^{\mathrm{d}}\end{array}$ & $\begin{array}{c}\text { Bank } \\
\text { Stability } \\
\text { Rating }\end{array}$ \\
\hline Potentilla gracilis Dougl. ex Hook. & slender cinquefoil & $\mathrm{F}$ & $\mathrm{P}$ & $\mathrm{N}$ & FAC & poor \\
\hline Potentilla rivalis Nutt. & brook cinquefoil & $\mathrm{F}$ & $\mathrm{A} / \mathrm{B}$ & $\mathrm{N}$ & FACW & poor \\
\hline Pyrola asarifolia Michx. & liverleaf wintergreen & $\mathrm{F}$ & $\mathrm{P}$ & $\mathrm{N}$ & FACU & poor \\
\hline Ranunculus abortivus L. & littleleaf buttercup & $\mathrm{F}$ & $\mathrm{P}$ & $\mathrm{N}$ & FACW & poor \\
\hline Ranunculus acriformis Gray & sharpleaf buttercup & $\mathrm{F}$ & $\mathrm{P}$ & $\mathrm{N}$ & FACW & poor \\
\hline Ranunculus aquatilis L. & whitewater crowfoot & $\mathrm{F}$ & $\mathrm{P}$ & $\mathrm{N}$ & OBL & poor \\
\hline Ranunculus cymbalaria Pursh & alkali buttercup & $\mathrm{F}$ & $\mathrm{P}$ & $\mathrm{N}$ & OBL & poor \\
\hline Ranunculus macounii Britt. & Macoun's buttercup & $\mathrm{F}$ & $\mathrm{P}$ & $\mathrm{N}$ & OBL & poor \\
\hline Ranunculus L. & buttercup & $\mathrm{F}$ & $\mathrm{P}$ & $\mathrm{N}$ & $\mathrm{n} / \mathrm{a}$ & poor \\
\hline Rhus trilobata Nutt. & skunkbush sumac & $\mathrm{S}$ & $\mathrm{P}$ & $\mathrm{N}$ & UPL & good \\
\hline Ribes L. & currant & $\mathrm{S}$ & $\mathrm{P}$ & $\mathrm{N}$ & FACU & good \\
\hline Rosa woodsii Lindl. & Woods' rose & $\mathrm{S}$ & $\mathrm{P}$ & $\mathrm{N}$ & FAC & good \\
\hline Rudbeckia occidentalis Nutt. & western coneflower & $\mathrm{F}$ & $\mathrm{P}$ & $\mathrm{N}$ & FACW & poor \\
\hline Rumex aquaticus L. & western dock & $\mathrm{F}$ & $\mathrm{P}$ & $\mathrm{N}$ & FAC & fair \\
\hline Rumex crispus L. & curly dock & $\mathrm{F}$ & $\mathrm{P}$ & $\mathrm{E}$ & FACW & fair \\
\hline Salix bebbiana Sarg. & Bebb willow & $\mathrm{S}$ & $\mathrm{P}$ & $\mathrm{N}$ & FACW & excellent \\
\hline Salix boothii Dorn & Booth's willow & $\mathrm{S}$ & $\mathrm{P}$ & $\mathrm{N}$ & FACW & excellent \\
\hline Salix drummondiana Barratt ex Hook. & Drummond's willow & $\mathrm{S}$ & $\mathrm{P}$ & $\mathrm{N}$ & OBL & excellent \\
\hline Salix exigua Nutt. & narrowleaf willow & $\mathrm{S}$ & $\mathrm{P}$ & $\mathrm{N}$ & OBL & excellent \\
\hline Salix farriae Ball & Farr's willow & $\mathrm{S}$ & $\mathrm{P}$ & $\mathrm{N}$ & FACW & excellent \\
\hline Salix geyeriana Anderss. & Geyer's willow & $\mathrm{S}$ & $\mathrm{P}$ & $\mathrm{N}$ & FACW & excellent \\
\hline Salix lemmonii Bebb & Lemmon's willow & $\mathrm{S}$ & $\mathrm{P}$ & $\mathrm{N}$ & FACW & excellent \\
\hline Salix lucida Muhl. ssp. caudata (Nutt.) E. Murr. & greenleaf willow & $\mathrm{S}$ & $\mathrm{P}$ & $\mathrm{N}$ & OBL & excellent \\
\hline Salix planifolia Pursh & diamondleaf willow & $\mathrm{S}$ & $\mathrm{P}$ & $\mathrm{N}$ & FACW & $\mathrm{n} / \mathrm{a}$ \\
\hline Saxifraga oregana T.J. Howell & Oregon saxifrage & $\mathrm{F}$ & $\mathrm{P}$ & $\mathrm{N}$ & FACU & poor \\
\hline Saxifraga L. & saxifrage & $\mathrm{F}$ & $\mathrm{P}$ & $\mathrm{N}$ & $\mathrm{n} / \mathrm{a}$ & poor \\
\hline Senecio hydrophiloides Rydb. & tall groundwel & $\mathrm{F}$ & $\mathrm{P}$ & $\mathrm{N}$ & FACW & fair \\
\hline Senecio serra Hook. & tall ragwort & $\mathrm{F}$ & $\mathrm{P}$ & $\mathrm{N}$ & FACU & fair \\
\hline Senecio sphaerocephalus Greene & ballhead ragwort & $\mathrm{F}$ & $\mathrm{P}$ & $\mathrm{N}$ & FACW & fair \\
\hline Silene menziesii Hook. & Menzies' campion & $\mathrm{F}$ & $\mathrm{P}$ & $\mathrm{N}$ & FAC & poor \\
\hline Sisyrinchium idahoense Bickn. & Idaho blue-eyed grass & $\mathrm{F}$ & $\mathrm{P}$ & $\mathrm{N}$ & FACW & poor \\
\hline Sisyrinchium montanum Greene & strict blue-eyed grass & $\mathrm{F}$ & $\mathrm{P}$ & $\mathrm{N}$ & FACW & $\mathrm{n} / \mathrm{a}$ \\
\hline Solidago canadensis L. & Canada goldenrod & $\mathrm{F}$ & $\mathrm{P}$ & $\mathrm{N}$ & FACU & fair \\
\hline
\end{tabular}

Appendix B - 5 


\begin{tabular}{|c|c|c|c|c|c|c|}
\hline Scientific Name & Common Name & $\begin{array}{c}\text { Growth } \\
\text { Form }^{\text {a }}\end{array}$ & Duration $^{\mathrm{b}}$ & Nativity $^{\mathrm{c}}$ & $\begin{array}{l}\text { Wetland } \\
\text { Indicator } \\
\text { Status }^{\mathrm{d}}\end{array}$ & $\begin{array}{c}\text { Bank } \\
\text { Stability } \\
\text { Rating } \\
\end{array}$ \\
\hline Stellaria crassifolia Ehrh. & fleshy starwort & $\mathrm{F}$ & $\mathrm{P}$ & $\mathrm{N}$ & FACW & poor \\
\hline Stellaria longifolia Muhl. ex Willd. & longleaf starwort & $\mathrm{F}$ & $\mathrm{P}$ & $\mathrm{N}$ & FACW & poor \\
\hline Stellaria L. & starwort & $\mathrm{F}$ & $\mathrm{P}$ & $\mathrm{N}$ & $\mathrm{n} / \mathrm{a}$ & poor \\
\hline Symphyotrichum foliaceum (DC.) Nesom & alpine leafybract aster & $\mathrm{F}$ & $\mathrm{P}$ & $\mathrm{N}$ & FACW & $\mathrm{n} / \mathrm{a}$ \\
\hline Symphyotrichum spathulatum (Lindl.) Nesom & western mountain aster & $\mathrm{F}$ & $\mathrm{P}$ & $\mathrm{N}$ & FAC & $\mathrm{n} / \mathrm{a}$ \\
\hline Symphyotrichum subspicatum (Nees) Nesom & Douglas aster & $\mathrm{F}$ & $\mathrm{P}$ & $\mathrm{N}$ & FACW & $\mathrm{n} / \mathrm{a}$ \\
\hline Symphyotrichum Nees & aster & $\mathrm{F}$ & $\mathrm{P}$ & $\mathrm{N}$ & $\mathrm{n} / \mathrm{a}$ & poor \\
\hline Taraxacum officinale G.H. Weber ex Wiggers & common dandelion & $\mathrm{F}$ & $\mathrm{P}$ & $\mathrm{E}$ & FACU & poor \\
\hline Thalictrum occidentale Gray & western meadow-rue & $\mathrm{F}$ & $\mathrm{P}$ & $\mathrm{N}$ & FACU & poor \\
\hline Thermopsis montana Nutt. & mountain goldenbanner & $\mathrm{F}$ & $\mathrm{P}$ & $\mathrm{N}$ & UPL & fair \\
\hline Thlaspi arvense L. & field pennycress & $\mathrm{F}$ & $\mathrm{A} / \mathrm{B}$ & $\mathrm{E}$ & UPL & poor \\
\hline Tragopogon dubius Scop. & yellow salsify & $\mathrm{F}$ & $\mathrm{A} / \mathrm{B}$ & $\mathrm{E}$ & UPL & $\mathrm{n} / \mathrm{a}$ \\
\hline Trifolium longipes Nutt. & longstalk clover & $\mathrm{F}$ & $\mathrm{P}$ & $\mathrm{N}$ & FAC & poor \\
\hline Trifolium repens L. & white clover & $\mathrm{F}$ & $\mathrm{A} / \mathrm{B}$ & $\mathrm{E}$ & FAC & poor \\
\hline Triglochin palustre L. & marsh arrowgrass & $\mathrm{F}$ & $\mathrm{P}$ & $\mathrm{N}$ & OBL & poor \\
\hline Urtica dioica $\mathrm{L}$ & stinging nettle & $\mathrm{F}$ & $\mathrm{P}$ & $\mathrm{N}$ & FAC & fair \\
\hline Veronica americana Schwein. ex Benth. & American speedwell & $\mathrm{F}$ & $\mathrm{P}$ & $\mathrm{N}$ & OBL & poor \\
\hline Veronica serpyllifolia L. & thymeleaf speedwell & $\mathrm{F}$ & $\mathrm{P}$ & $\mathrm{E}$ & FAC & poor \\
\hline Viola nephrophylla Greene & northern bog violet & $\mathrm{F}$ & $\mathrm{P}$ & $\mathrm{N}$ & FACU & poor \\
\hline Viola L. & violet & $\mathrm{F}$ & $\mathrm{P}$ & $\mathrm{N}$ & $\mathrm{n} / \mathrm{a}$ & poor \\
\hline
\end{tabular}

${ }^{\mathrm{a}} \mathrm{F}=$ forb/fern, $\mathrm{G}=$ graminoid, $\mathrm{S}=$ shrub, $\mathrm{T}=$ tree

${ }^{\mathrm{b}} \mathrm{A} / \mathrm{B}=$ annual/biennial, $\mathrm{P}=$ perennial

${ }^{\mathrm{c}} \mathrm{E}=$ exotic, $\mathrm{N}=$ native

${ }^{\mathrm{d}} \mathrm{OBL}=$ obligate wetland, FACW = facultative wetland, FAC = facultative, FACU = facultative upland, UPL = obligate upland

e rating was calculated for species occurring in greenline samples only 


\section{APPENDIX C. Location AND CONDITION RATING OF SAMPLE REACHES.}



Appendix C. Location and condition rating of sample reaches.

\begin{tabular}{|c|c|c|c|c|c|c|c|c|}
\hline \multirow[b]{2}{*}{ Site Code } & \multirow[b]{2}{*}{ Stream } & \multicolumn{2}{|c|}{ Location } & \multirow{2}{*}{$\begin{array}{c}\text { PFC } \\
\text { Rating }^{\mathrm{a}}\end{array}$} & \multirow{2}{*}{$\begin{array}{l}\text { VIBI } \\
\text { Score }\end{array}$} & \multirow{2}{*}{$\begin{array}{l}\text { VIBI Condition } \\
\text { Class }\end{array}$} & \multirow{2}{*}{$\begin{array}{l}\text { Disturbance } \\
\text { Score }\end{array}$} & \multirow{2}{*}{$\begin{array}{c}\text { Disturbance } \\
\text { Category }\end{array}$} \\
\hline & & Latitude & Longitude & & & & & \\
\hline CAMP & Camp Cr. & 45.68156616 & -112.56099008 & FAR & 0.60 & moderately impaired & 0.59 & moderate \\
\hline MORRISON & Morrison Cr. & 44.70083328 & -113.05396895 & FAR & 0.64 & moderately impaired & 0.80 & most \\
\hline NF_EVRSN & North Fork Everson Cr. & 44.90777384 & -113.33167515 & PFC & 0.75 & reference & 0.14 & least \\
\hline EF_BLACK & East Fork Blacktail Deer Cr. & 44.84571892 & -112.20396350 & PFC & 0.61 & moderately impaired & 0.36 & moderate \\
\hline WF_BLACK & West Fork Blacktail Deer Cr. & 44.78252959 & -112.31075800 & NF & 0.37 & severely impaired & 0.80 & most \\
\hline PRICE_DN & Middle Fork Price Cr. & 44.57434567 & -112.12498066 & PFC & 0.94 & reference & 0.04 & least \\
\hline L_BEAVER & Little Beaver Cr. & 44.52808267 & -112.47752761 & FAR & 0.59 & moderately impaired & 0.40 & moderate \\
\hline L_SHEEP & Little Sheep Cr. & 44.58333903 & -112.67295781 & NF & 0.47 & severely impaired & 0.53 & moderate \\
\hline L_SAGE & Little Sage Cr. & 44.79545642 & -112.52678974 & FAR & 0.47 & severely impaired & 0.77 & most \\
\hline MUDDY_TR & Tributary of Muddy Cr. & 44.72151009 & -112.89286223 & NF & 0.64 & moderately impaired & 0.71 & moderate \\
\hline MCNINCH & McNinch Cr. & 44.69827957 & -112.87387689 & FAR & 0.68 & moderately impaired & 0.40 & moderate \\
\hline NICHO_DN & Nicholia Cr. & 44.54776607 & -112.82693010 & PFC & 0.70 & moderately impaired & 0.73 & moderate \\
\hline TENDOY & Tendoy Cr. & 44.45170686 & -112.92159908 & NF & 0.53 & moderately impaired & 0.56 & moderate \\
\hline NICHO_UP & Nicholia Cr. & 44.45793453 & -112.91187976 & PFC & 0.54 & moderately impaired & 0.51 & moderate \\
\hline $\mathrm{COW}$ & Cow Cr. & 44.65020038 & -112.95523105 & NF & 0.68 & moderately impaired & 0.47 & moderate \\
\hline INDIAN & Indian Cr. & 44.60515310 & -113.00577929 & PFC & 0.76 & reference & 0.00 & least \\
\hline PRICE_UP & Middle Fork Price Cr. & 44.56140133 & -112.12400492 & PFC & 0.82 & reference & 0.30 & least \\
\hline L_SAGE_T & Tributary of Little Sage Cr. & 44.81923495 & -112.43812202 & NF & 0.54 & moderately impaired & 0.41 & moderate \\
\hline EAST & East Cr. & 44.86921884 & -112.54489046 & NF & 0.86 & reference & 0.28 & least \\
\hline BL_CANYN & Black Canyon Cr. & 44.86336458 & -113.32877526 & PFC & 0.80 & reference & 0.08 & least \\
\hline NF_DIVDE & North Fork Divide Cr. & 44.81897227 & -113.32126491 & FAR & 0.88 & reference & 0.52 & moderate \\
\hline HORSE_PR & Horse Prairie Cr. & 44.81718742 & -113.20700767 & PFC & 0.71 & reference & 0.19 & least \\
\hline SHENON & Shenon Cr. & 44.92784061 & -113.22862124 & FAR & 0.68 & moderately impaired & 0.67 & moderate \\
\hline RAPE & Rape Cr. & 44.97097330 & -113.21309485 & NF & 0.47 & severely impaired & 0.88 & most \\
\hline TAYLR_UP & Taylor Cr. & 45.27322615 & -112.98248908 & NF & 0.23 & severely impaired & 0.94 & most \\
\hline TAYLR_DN & Taylor Cr. & 45.22943582 & -112.99539160 & PFC & 0.50 & moderately impaired & 0.28 & moderate \\
\hline BLD_DICK & Bloody Dick Cr. & 45.06979468 & -113.42391657 & PFC & 0.96 & reference & 0.09 & least \\
\hline BG_HOLLW & Big Hollow Cr. & 45.01306739 & -113.35803380 & FAR & 0.34 & severely impaired & 1.00 & most \\
\hline SF_WAT_U & South Fork Watson Cr. & 45.09592367 & -113.19631118 & NF & 0.41 & severely impaired & 0.91 & most \\
\hline SF_WAT_D & South Fork Watson Cr. & 45.07747150 & -113.19649282 & FAR & 0.40 & severely impaired & 0.52 & moderate \\
\hline
\end{tabular}

${ }^{\mathrm{a}} \mathrm{FAR}=$ functioning at risk, $\mathrm{PFC}=$ proper functioning condition, $\mathrm{NF}=$ nonfunctioning 